Florida International University FIU Digital Commons

$4-1-2005$

\title{
Cultural influences : visual traces of the Cuban community in Hialeah
}

José Antonio Aguada

Florida International University

DOI: $10.25148 /$ etd.FI13101539

Follow this and additional works at: https://digitalcommons.fiu.edu/etd

Part of the Architecture Commons

\section{Recommended Citation}

Aguada, José Antonio, "Cultural influences : visual traces of the Cuban community in Hialeah" (2005). FIU Electronic Theses and Dissertations. 1212.

https://digitalcommons.fiu.edu/etd/1212

This work is brought to you for free and open access by the University Graduate School at FIU Digital Commons. It has been accepted for inclusion in FIU Electronic Theses and Dissertations by an authorized administrator of FIU Digital Commons. For more information, please contact dcc@fiu.edu. 
FLORIDA INTERNATIONAL UNIVERSITY

Miami, Florida

CULTURAL INFLUENCES: VISUAL TRACES OF

THE CUBAN COMMUNITY IN HIALEAH

A thesis submitted in partial fulfillment of the

requirements for the degree of

MASTER OF ARCHITECTURE

by

José Antonio Aguada

2005 
This thesis, written by José Antonio Aguada, and entitled Cultural Influences: Visual Traces of the Cuban Community in Hialeah, having been approved in respect to style and intellectual content, is referred to you for judgment.

We have read this thesis and recommend that it be approved.

Damián J. Fernández

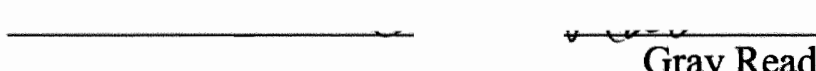

Gray Read

Y/ícolás Quintana, Major Professor

Date of Defense: April 1, 2005

The thesis of José Antonio Aguada is approved.

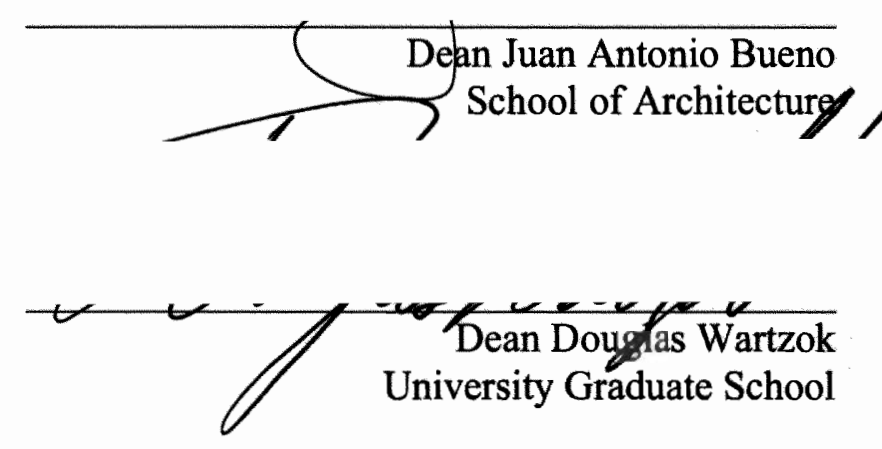

Florida International University, 2005 
CC Copyright 2005 by José Antonio Aguada

All rights reserved. 


\section{DEDICATION}

I dedicate this thesis to my parents and loved ones who are physically here and those who are in spirit. If not because of their love, patience, and strong belief in me, I would have never thought the completion of this work was possible. 


\section{ACKNOWLEDGMENTS}

I wish to thank the members of my committee for their support and most of all their patience. Their ability to be always there when needed has been greatly appreciated. John Stuart's guidance to explore laid the foundation that kept me going the entire time. Kevin Smith's knowledge of the digital world assisted in thinking beyond the physical. Damián Fernández's insight in the social and cultural sections of the research surprisingly brought light to the architectural as well. Gray Read's focus on deadlines and the talent of splitting herself to be helpful to everyone that walks through her door was very much cherished. Finally, there is my major professor, Nicolás Quintana. Although at times it seemed he mostly wanted to talk about what was occurring in his life, he always had a clear vision of what I was producing (probably better than I did), but most importantly, he kept motivating the completion of the work.

Each one of the professors I worked with during this process has given me the groundwork to be successful in architecture and in life through thought-provoking exercises. 


\section{ABSTRACT OF THE THESIS}

CULTURAL INFLUENCES: VISUAL TRACES OF THE CUBAN COMMUNITY IN HIALEAH

by

José Antonio Aguada

Florida International University, 2005

Miami, Florida

Professor Nicolás Quintana, Major Professor

This thesis examines specific changes and modifications made to the domestic architecture of Hialeah that relate to the construction of cultural identity. Much of the study is based upon oral histories from twelve (12) Cuban immigrants now residing in Hialeah, focusing on their renovated houses as architectural responses to cultural and social changes in their community and family life.

The research focused specifically on those renovations that transformed standard developers' houses into the "Cuban" home. A shared theme was the creation of additions, where the point of connections between the existing and the new structures as well as how these expansions created courtyards, became important to the study.

The design project is an addition to John F. Kennedy Library located on Henry L. Milander Park, which includes new computer areas and gallery spaces connecting the past and the present with Cubans in Hialeah and all over the world—connecting identities. 
TABLE OF CONTENTS

CHAPTER

PAGE

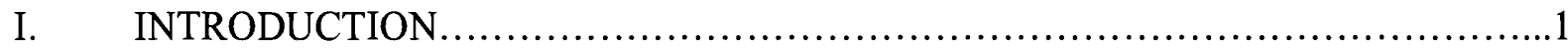

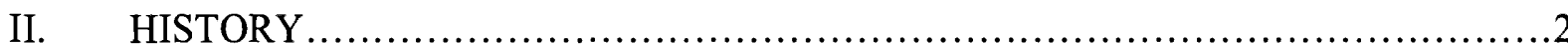

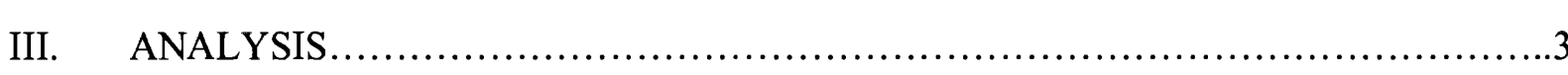

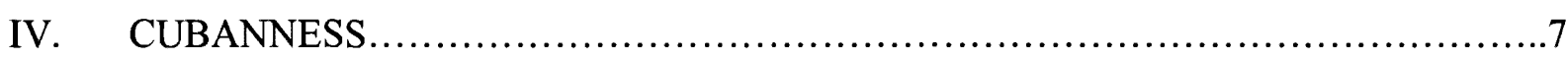

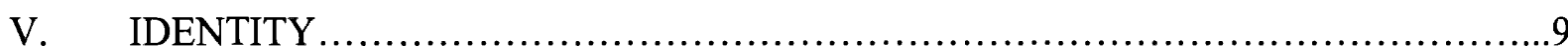

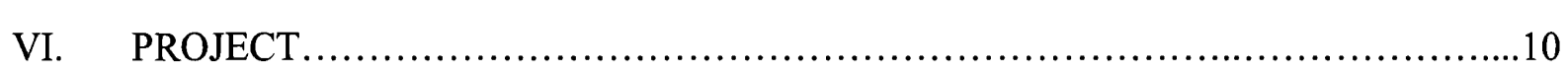

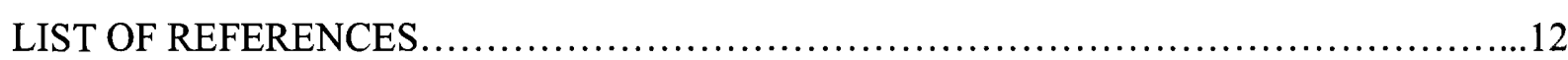

APPENDICES.... 
1. City of Hialeah Map

2. Downtown Hialeah, 1924.

3. Hialeah Race Track, 1924

. .2

4. Cuban Cultural Heritage Monument

5. Cuban Cultural Heritage Monument.

.3

6. Case Study Front Porch and Parking Area

.3

7. Case Study Side/Rear Aluminum Porch.

8. Case Study Rear Addition

.5

9. Case Study Additions

10. Patio in La Habana.

11. Floor Plans of Homes in La Habana..

...7

12. Milander Park Aerial

13. John F. Kennedy Library 


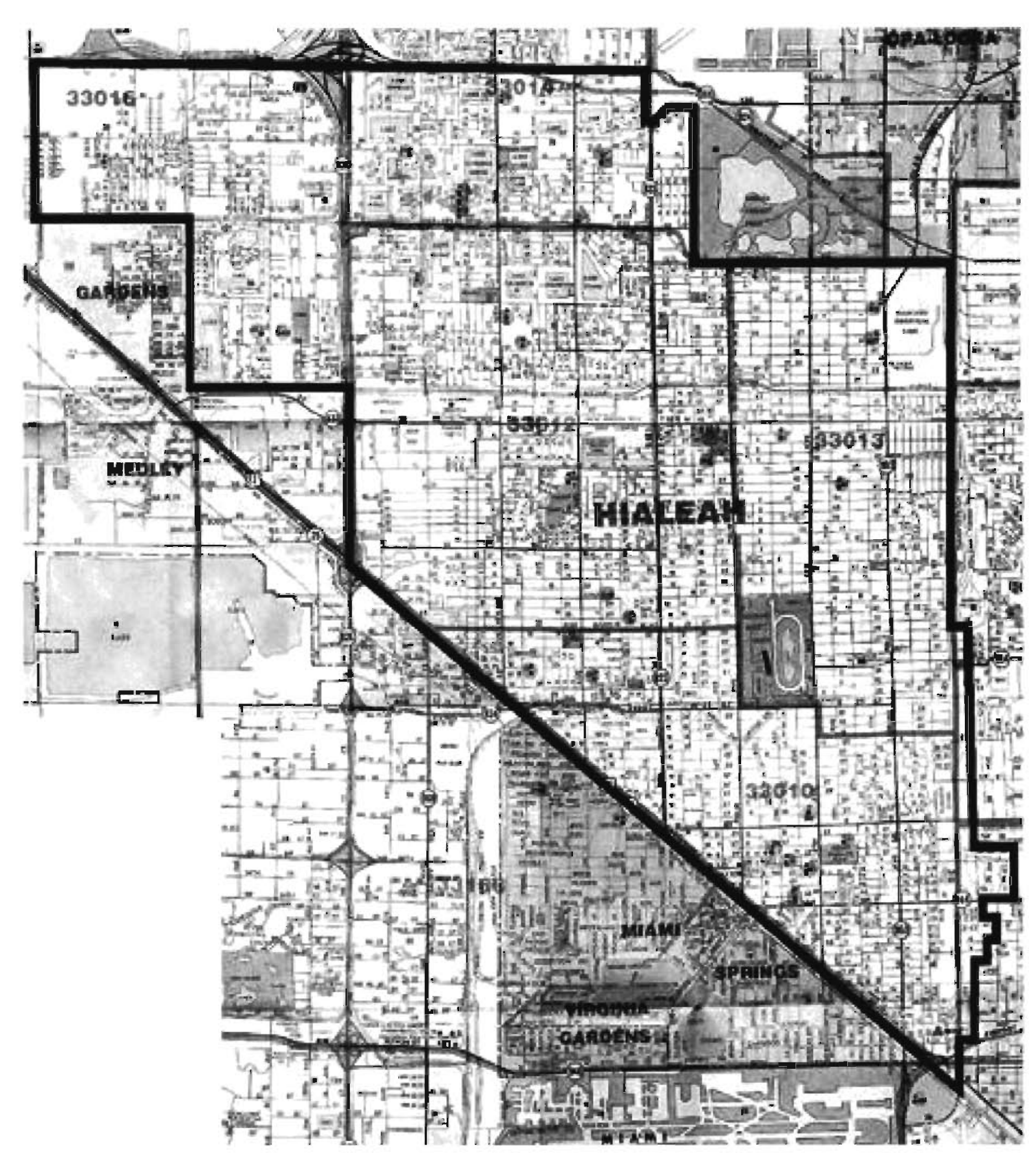

Fig. 1 City of Hialeah Map

\section{$\underline{\text { Introduction }}$}

The architecture of Hialeah has never been the focus of serious study. This project examines the physical, spatial and urban impact on the city of Hialeah resulting from the influx of Cuban immigrants since 1960. The initial phase involved an analysis of existing architectural conditions in Hialeah and a survey of members of the Cuban-American community in order to determine specific changes and modifications made to the architecture of Hialeah that relates to the construction of cultural identities. Oral histories from twelve (12) Cuban immigrant families now residing in Hialeah were gathered evaluating their physical responses to changes in their political, community and family experiences while residents of Hialeah. These ideas are explored through the design of a community center that enables and promotes an understanding of the community history and by the community itself.

Why Hialeah? Why Cuban-Americans? Many cities have high volumes of immigrant populations who create their own identity in terms of there new surroundings, but it was my own prejudice that led me towards trying to understand my people, my city and what leads us to do what we do and why? The Miami Herald Staff Writer Fabiola Santiago writes: "Forty years after the Cuban Revolution, Miami still gets the headlines and the hype: 'Havana, U.S.A.,' the capital of exile. But it is Miami-Dade's second largest city - Hialeah - that has become America's most Cuban city." I am a Cuban-American and I live in Hialeah, but what makes Hialeah a "Cuban city"? Are there any visual or architectural reactions common to Cuban immigrants within Hialeah? Does architecture communicate to everyone from Cubans residing in Hialeah to the public at large? What is "Cubanness" and how does it relate to architecture?

${ }^{1}$ Fabiola Santiago, Hialeah, The Miami Herald, 2000: Hialeah, 4L. 


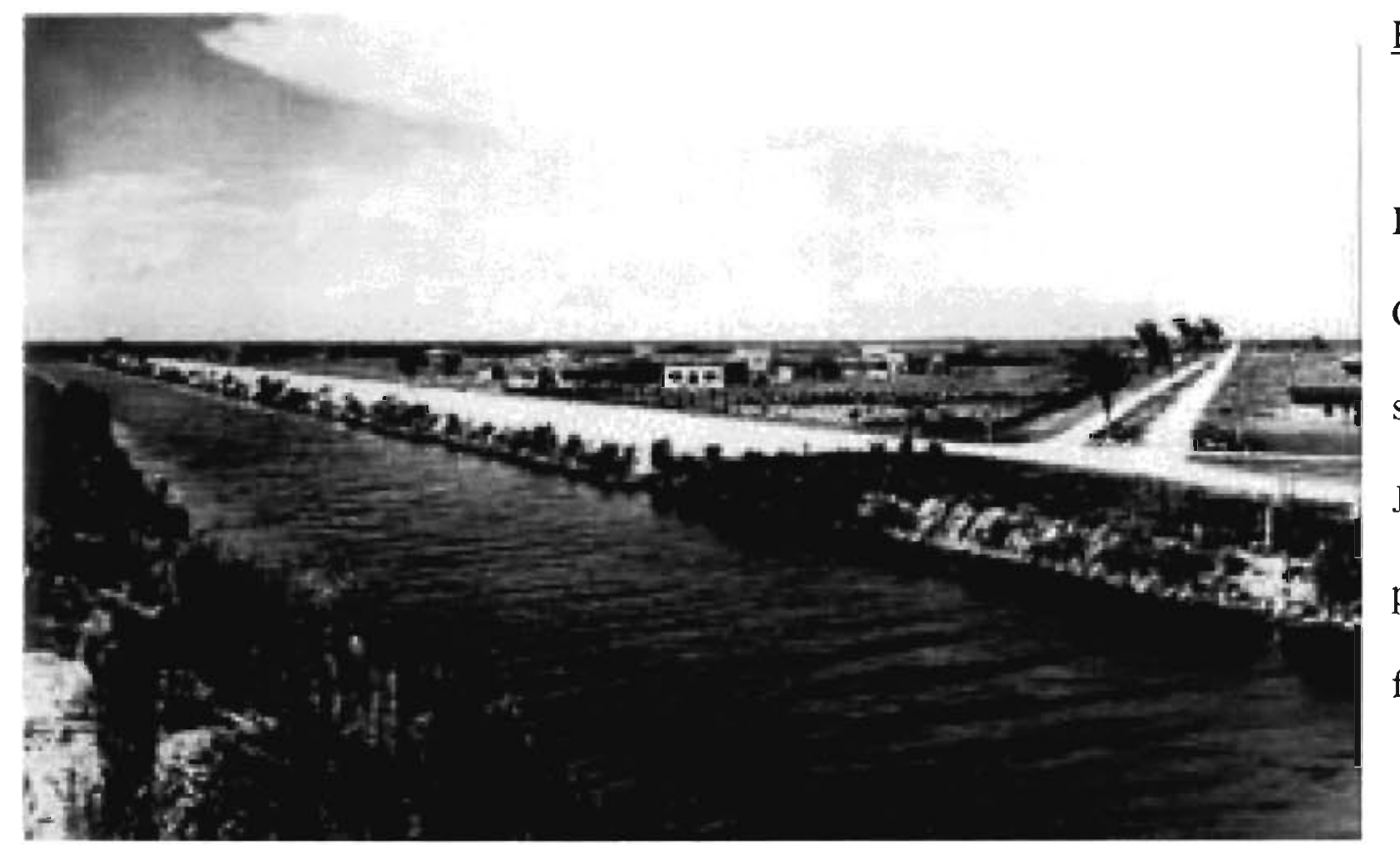

Fig. 2 Downtown Hialeah, 1924

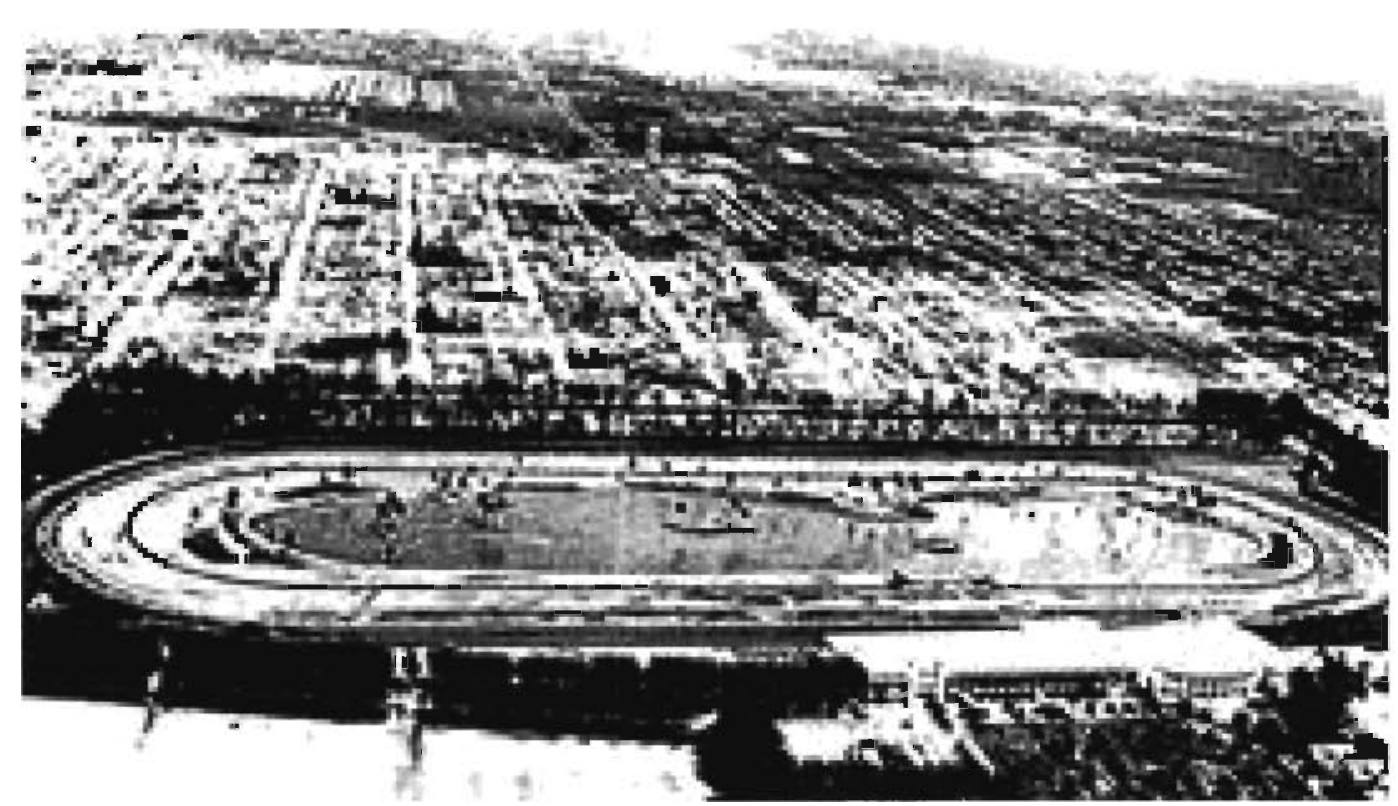

Fig. 3 Hialeah Race Track, 1924

"T. Boswell \& j. Curtis, The Cuban-American Experience, 1983:78.

III http://ci.hialeah.fl.us/general/history/

${ }^{\text {IV }}$ Fabiola Santiago, Hialeah, The Miami Herald, 2000: Hialeah, 5L. $\underline{\text { History }}$

Hialeah is an Indian name, meaning high prairie because of its historically grassy plains that were used by the native Indians that came from the everglades to display their products and trade with the residents of Miami. In 1921, pioneer aviator Glenn Curtiss and Missouri cattleman James H. Bright came to Hialeah with a greater vision. Incorporated in 1925, Hialeah slowly developed around Hialeah park horse track, at that time it was the city's "central attraction and landmark." "II From Spanish Jai-Alai to greyhound and horse track racing and to even silent movies, in the early 1920 's "Hialeah was the place to be." From a population of 1,500 in 1925, when one of the city's first slogan was "All ways lead to Hialeah," to now being ranked Florida's fifth-largest city with more than 210,000 residents. III

In 1960, the year the exodus that resulted from the Cuban Revolution, a large population boom occurred in Hialeah, the second largest city in Miami-Dade County. For many reasons, Hialeah was a particularly inviting location for Cuban immigrants to settle. There were many job openings in the racetrack and in the light manufacturing industry, essential for the blue-collar working class. There was also inexpensive land available for the development of new housing, as well as an increasing population of other Spanish speakers that enabled new arrivals to carry out their activities without the need of the English language. In 1960, the population of Hialeah was at 67,000 inhabitants. By 1970 , ten years after the first Cuban exodus, the population increased to 102,000 inhabitants. In 1990, the time of the last available census data, 87.6 percent of Hialeah's population was Hispanic, and 64.9 percent of these were Cubans. ${ }^{\text {IV }}$ 


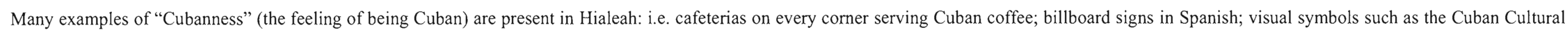

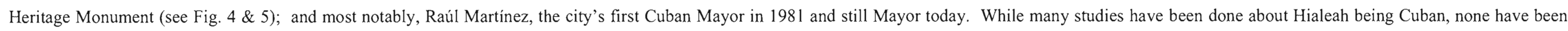

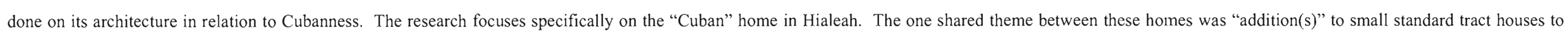

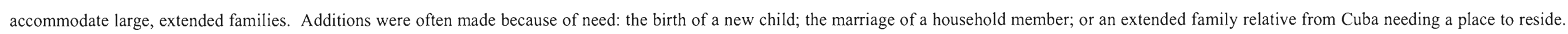

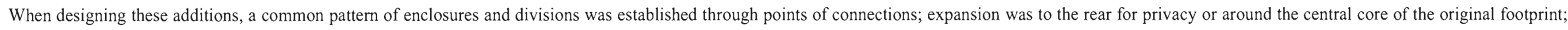
and changing uses as the need presented itself.

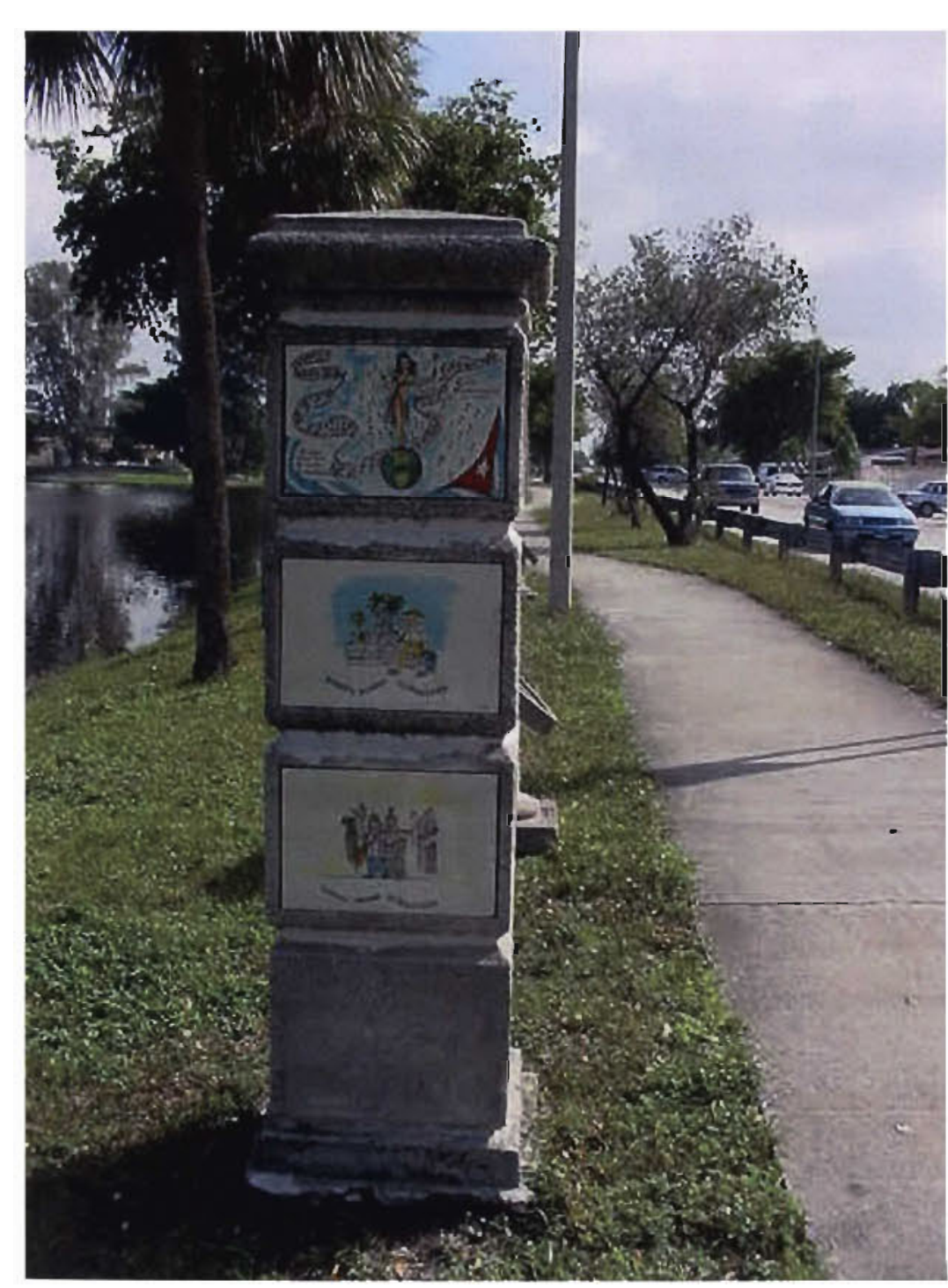

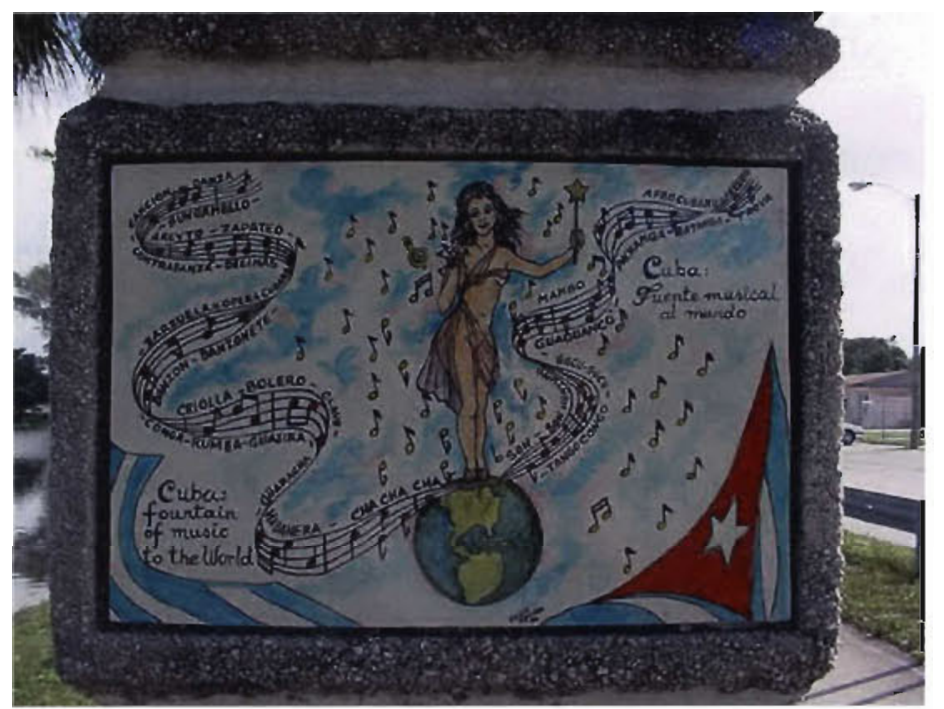

Fig. 5

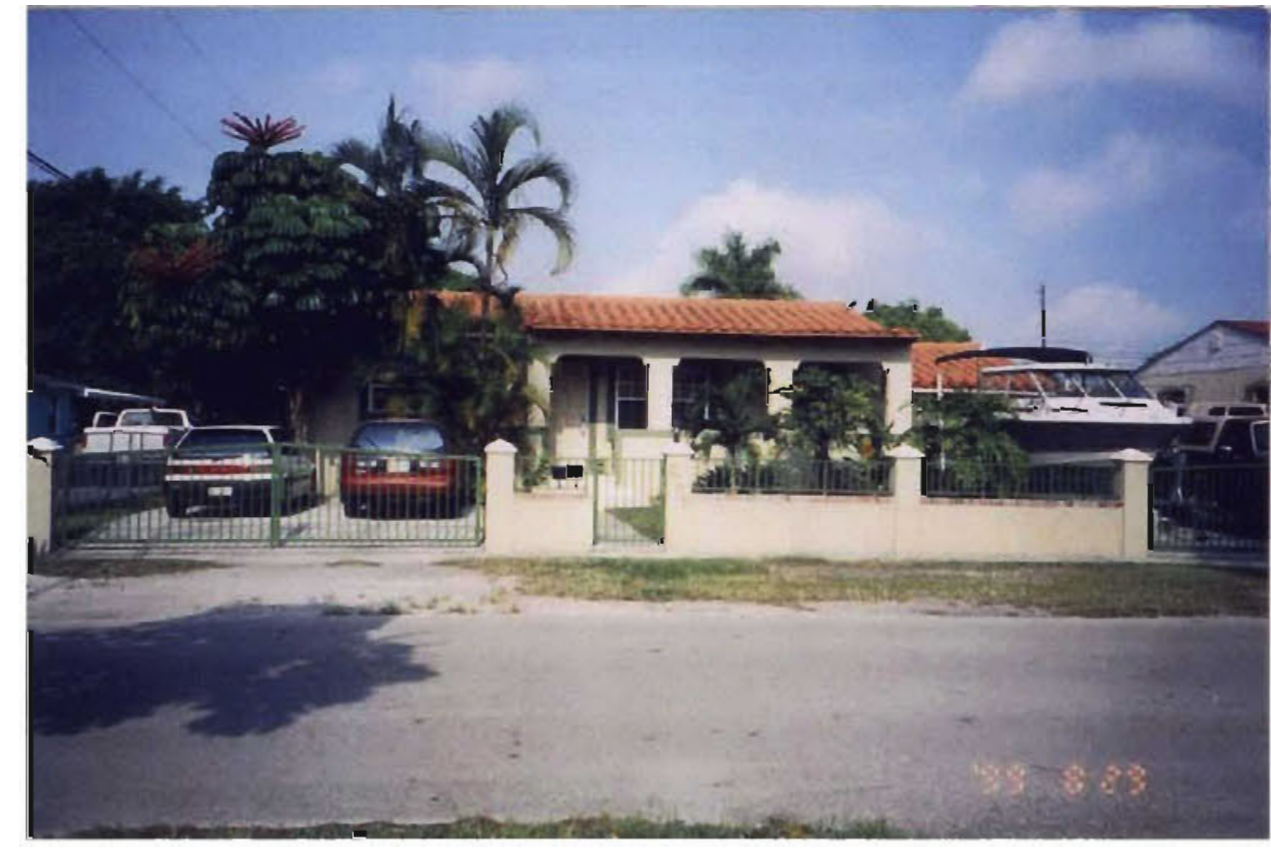

Although these additions are widely known among residents,

they are almost always hidden from the street for they are often not permitted and do not meet the zoning/building code. These are weekend jobs that satisfy their need, thus producing different shapes and finishes with no uniformity other than the paint finish. Due to zoning codes with restriction in setbacks and legality, the front is usually left intact. In certain cases, porches were added to the front of the house resembling the portales of Cuba, an outdoor seating area used predominantly in Cuba as gathering space for family and friends to converse (see Fig. 6). Commonly seen is the paving of the front yard to allow more parking area for many cars that a family has, because everyone of age drives to work or school. As the family grows, so 


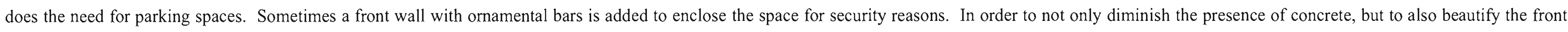

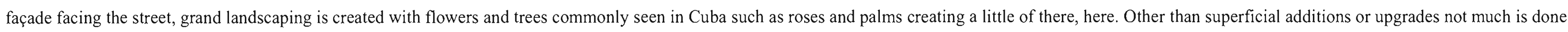
to the front façade because in order to have more done, permits are required and more money is needed to be spent; some do attain permits.

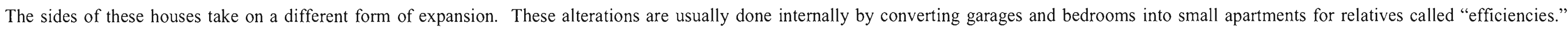

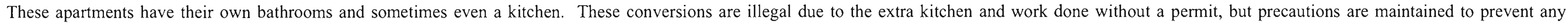

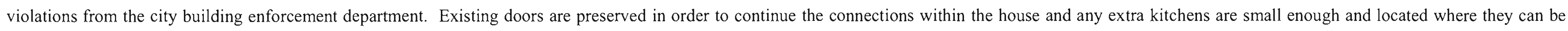

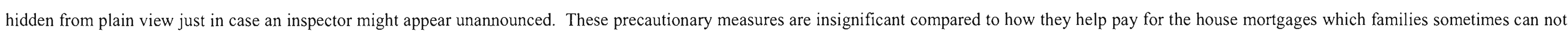

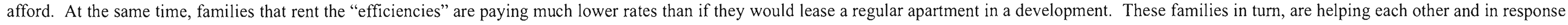

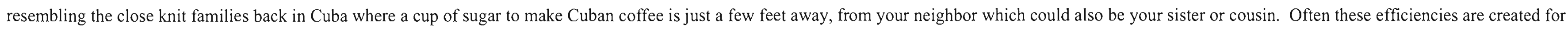

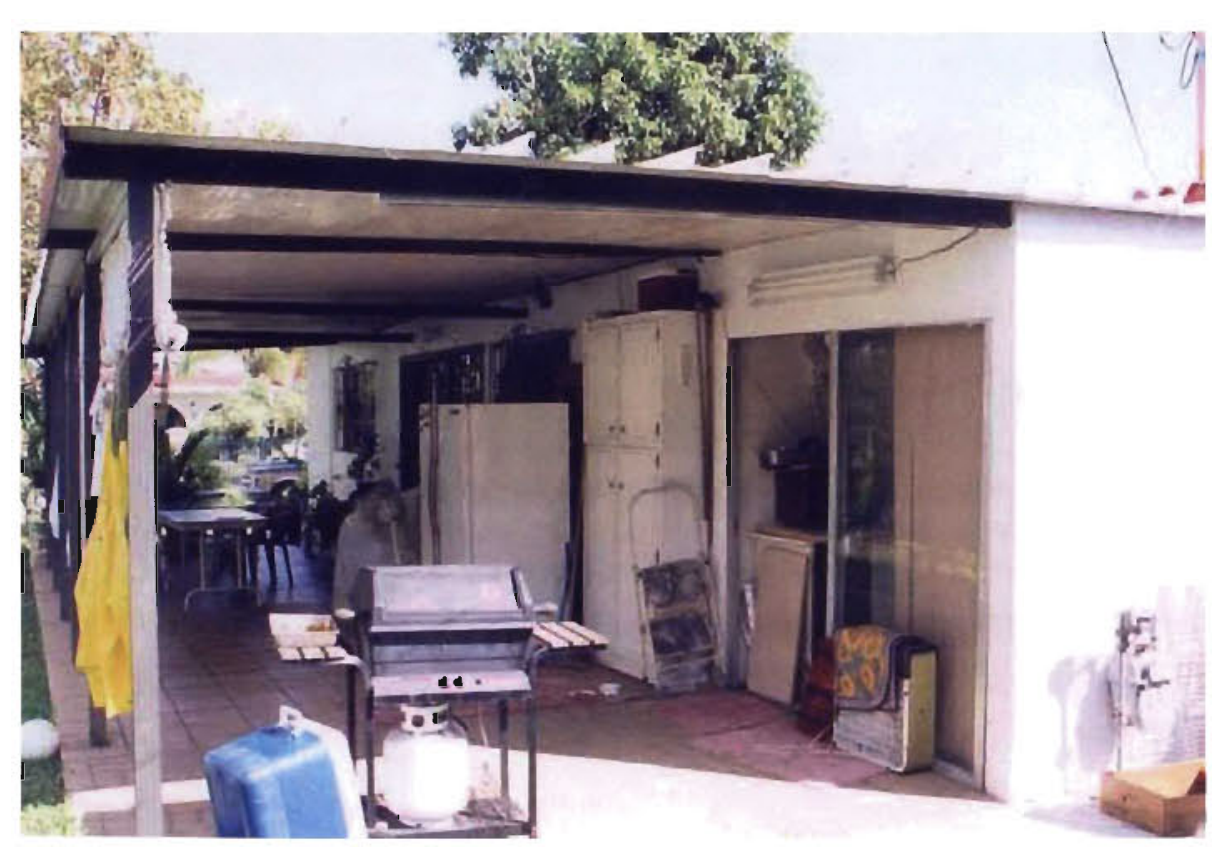

Fig. 7 Case Study Addition a member of the household that might need the privacy due to marriage or a new born child is added to the family circle. Cuban families tend to want to keep the family close and at times not want them to move out even after marriage. Mamá wants to keep their babies in her womb for life.

As seen on Figure 7, the sides as well as the rear of the house, an aluminum roof would be added for a carport that originally was sold and installed with permits. When some were removed, these aluminum roofs were sometimes sold or given away to be retrofitted in other houses with various usages such as covered seating areas or storage. Of course these were installed without a permit and at times they would also change use over time. A carport would be converted to a covered patio area and then in certain cases they would be converted to a room by enclosing the area with concrete block or wood stud with plywood and stucco and drywall finish on the walls and ceilings with insulation without a permit.

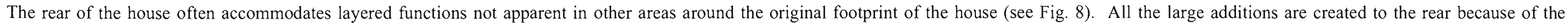

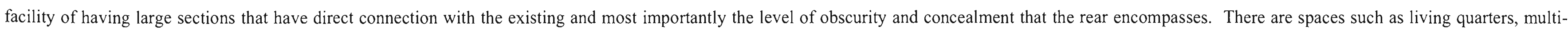




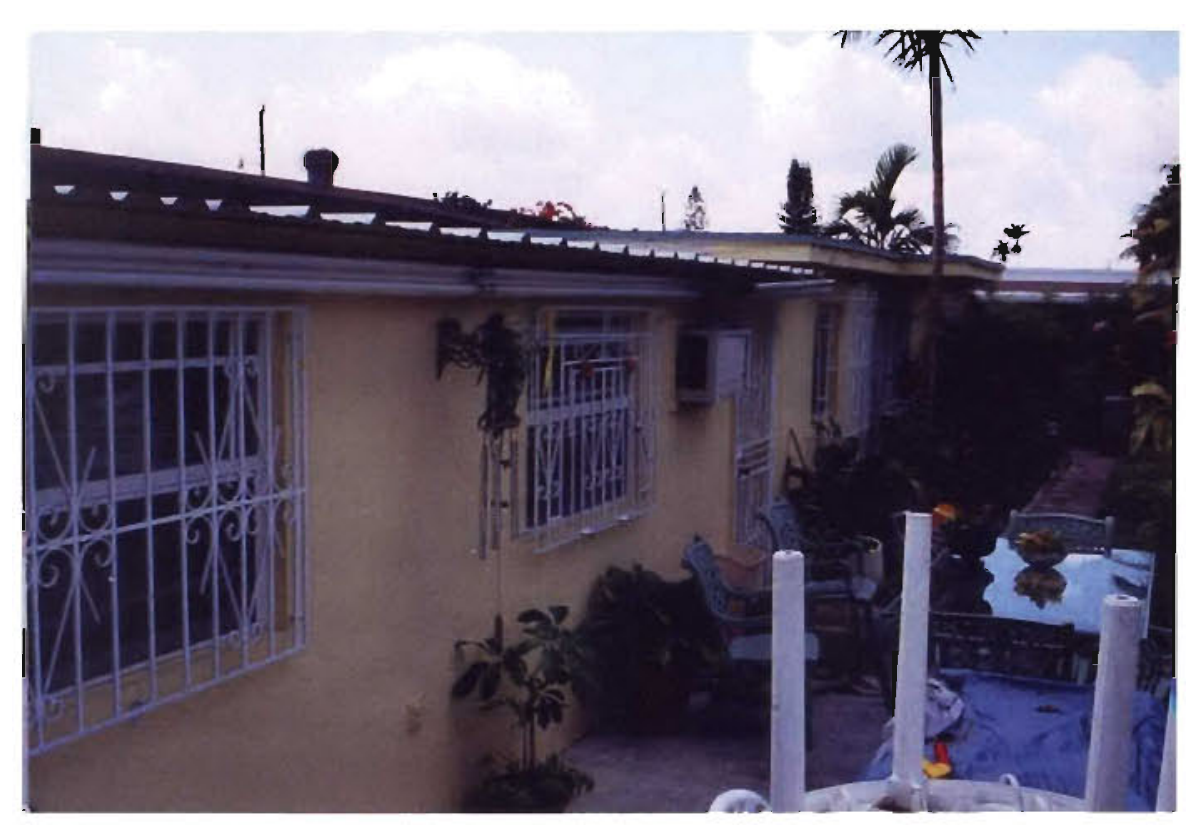

functional rooms like family room, covered and uncovered sitting areas, and even work or storage sections that are detached from the house. The backyard, small or large, also becomes a garden for tropical fruits and vegetables, as well as roosters and chickens that are reminiscent of

Cuba when everything they ate was grown at home.

Fig. 8 Case Study Addition

Television is often the main centerpiece for homes today. No longer is the front porch important for gathering. In Cuba, neighbors gathered on the front porch to drink Cuban coffee and watch the kids play. Moreover, there were usually only one or two televisions in the neighborhood, so everyone would gather in the front porch to watch the nightly novelas and gossip afterwards about everyday life or fulanito

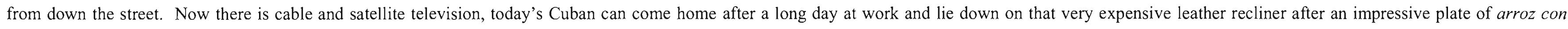

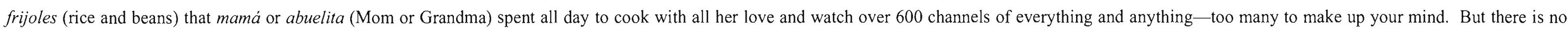

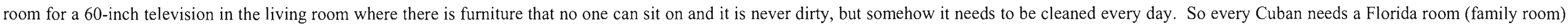

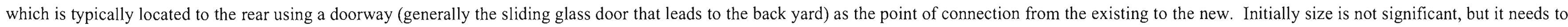

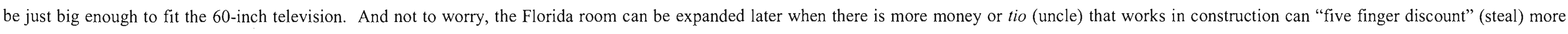
materials or like he says, "they were just throwing it away, so I picked them up" - unused!

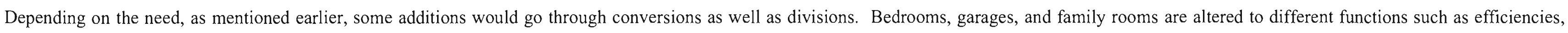

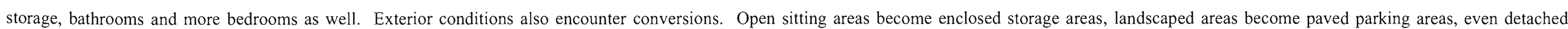

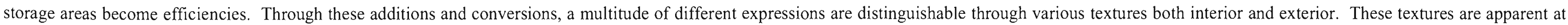

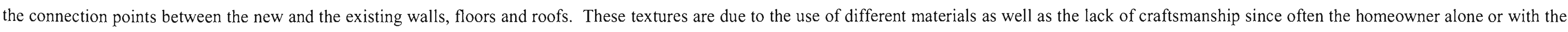

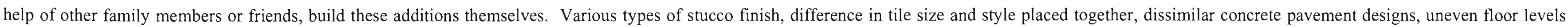
between additions (new and existing), and irregular drywall finishes are some examples of these textures. 


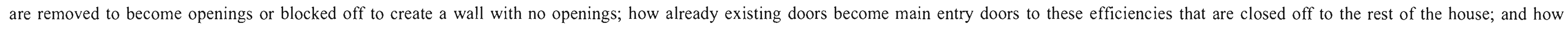

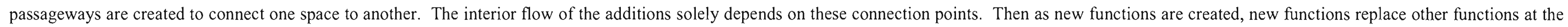
same lime some functions move or are removed altogether while the connection remains.
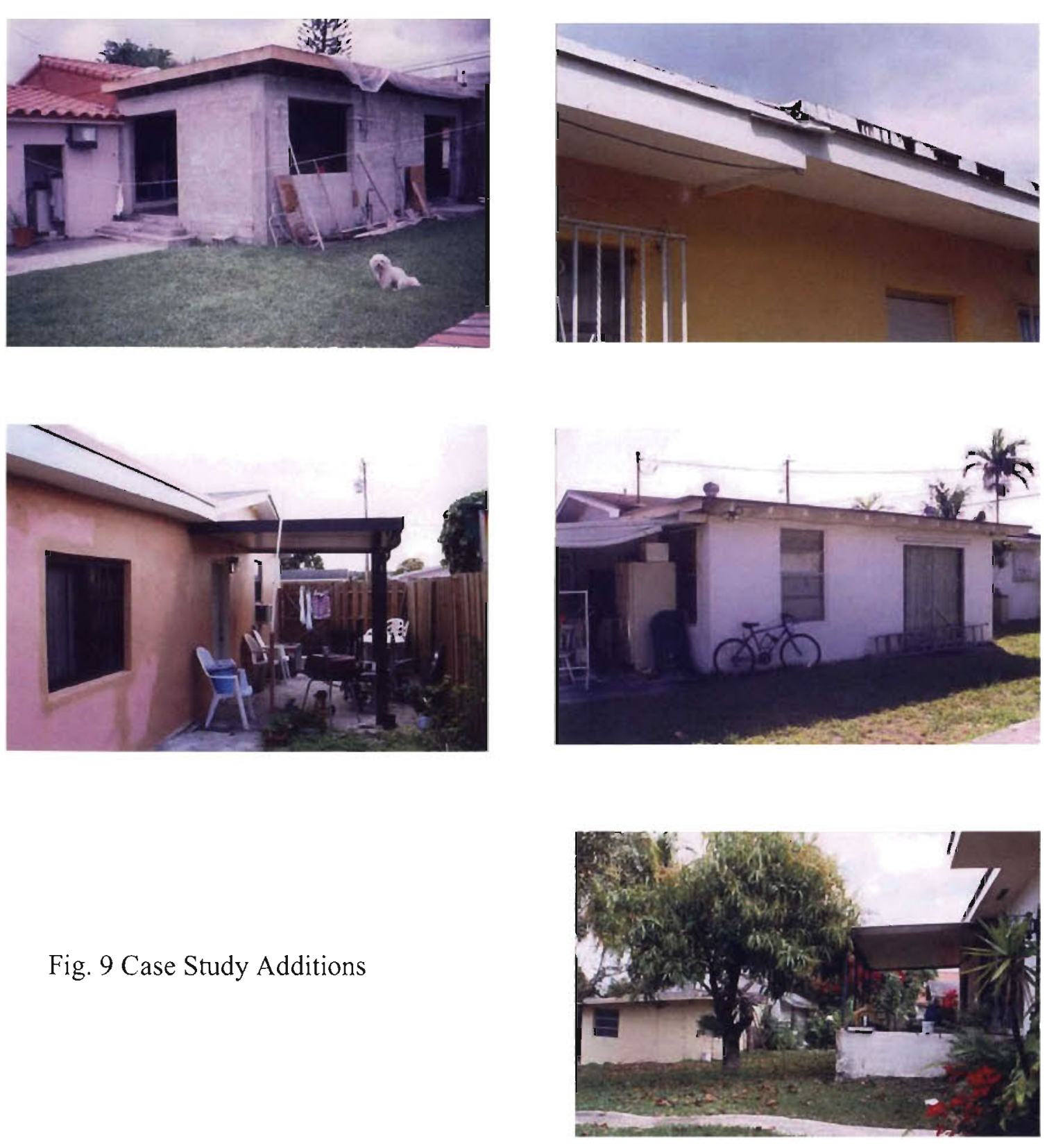

Fig. 9 Case Study Additions
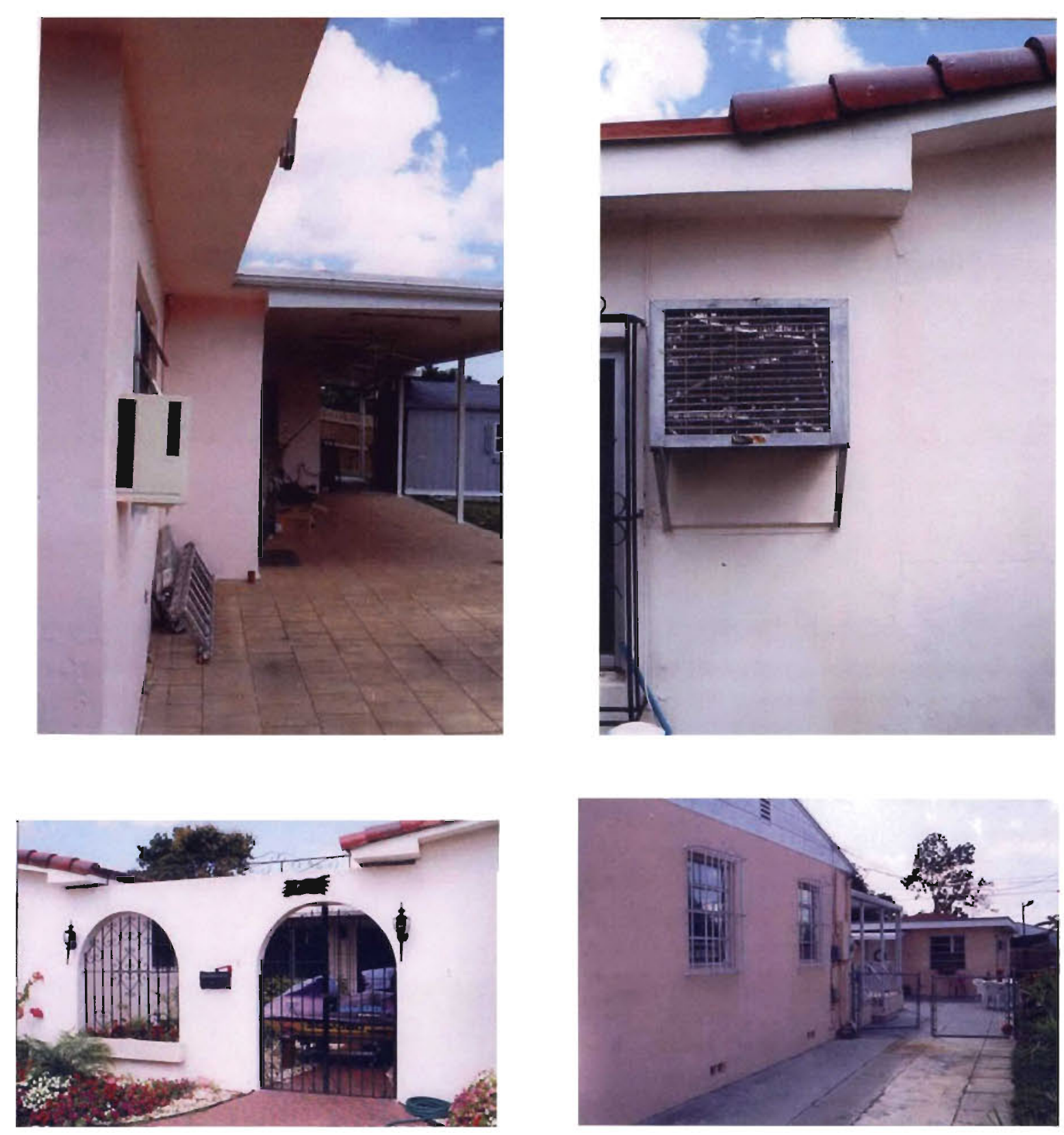


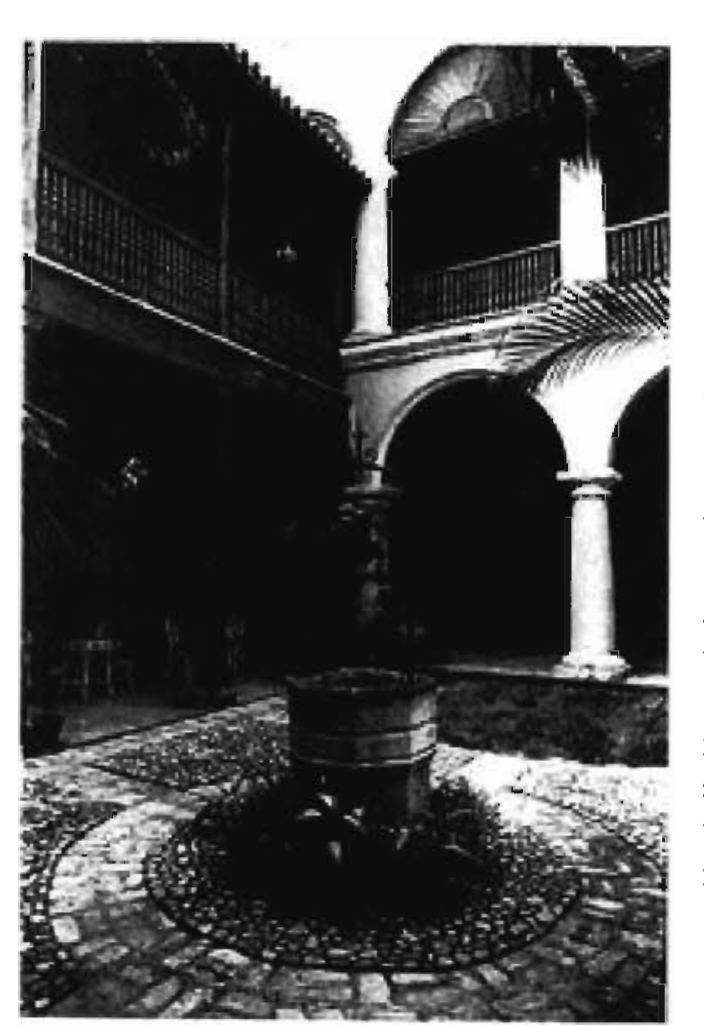

Fig. 10 La Habana Patio
Additions are the visual and architectural reactions that are common to the Cuban immigrant within Hialeah, but principally is how they are brought upon and then accomplished that makes it Cuban. The idea is that the addition is like an ajiaco. Fernando Ortiz in Los factores humanos de la cubanidad, (the human factors of Cubanness) published in 1940, uses the metaphor of ajiaco to illustrate how one word can resemble Cuban culture. Gustavo Pérez-Firmat explains in detail what ajiaco represents:

"He justifies the metaphor in a number of ways. First, since the ajiaco is made by combining a variety of meats and vegetables (whichever ones happen to be available), it conveys the ethnic diversity of Cuba. Second, the ajiaco is agglutinative but not synthetic; even if the diverse ingredients form part of a new culinary entity, they do not lose their original flavor and identity. So it is with Cuba, where the mixture of cultures has not led to a neoculturative synthesis, where each ethnic or cultural component has retained its identity. Third, an ajiaco is indefinitely replenishable, since new ingredients can be added to the stew as old ones are used up. In this respect, this dish symbolizes the continuing infusion of new elements into the Cuban cultural mix, those 'continuous transmigrations' that he had mentioned in the other essay. Lastly, ajiaco is itself an onomastic ajiaco, since it combines the African name of an Amerindian condiment, the aji or green pepper, with the Spanish suffix, -aco."

Perez-Firmat clearly shows how ajiaco symbolizes Cuban culture as a mixture of elements that while not losing its identity, continues to reinvent itself. These elements derived from many ancestry factors and are put together to become one, that constantly adds new consequent parts wherever its location or time. Cuban family additions, as described earlier, take on this element of being an ajiaco in that it is combination of functions

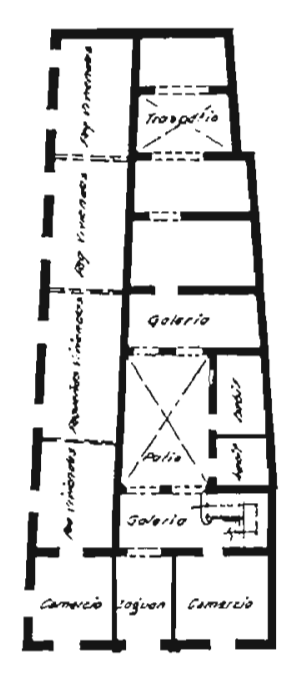

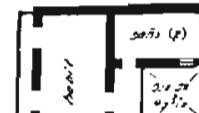

$4+2$

1

$+\frac{1}{2}+\frac{1}{2}$

$4-7=$ $1+-1 / 2$ $1+1$ sor
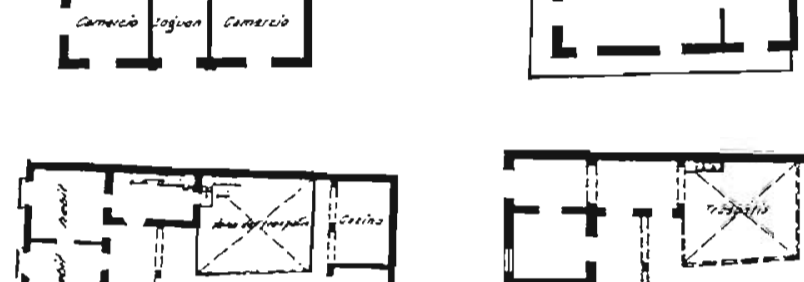

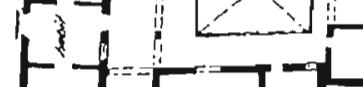

$F, 7=1$

$1+1+$

$\{3$

1

$1+1$

$-1$

$+1$

L

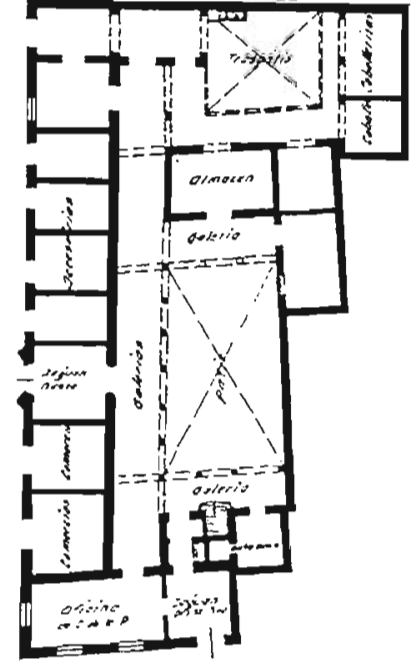

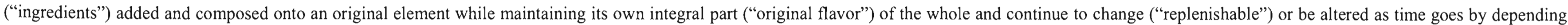
on what is available.

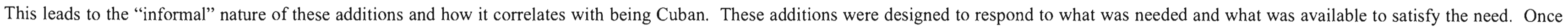

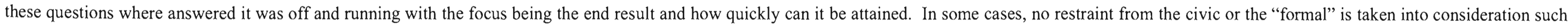

${ }^{v}$ Gustavo Pérez-Firmat, The Cuban Condition, 1989: 24. 


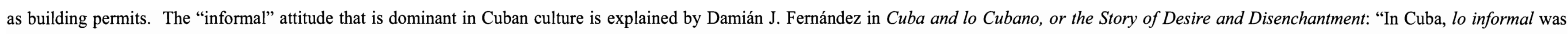

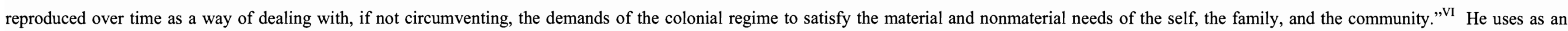

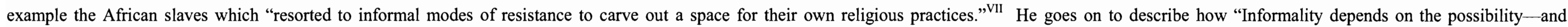

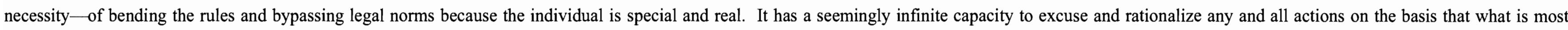

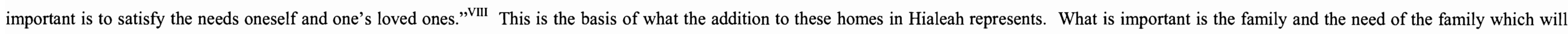
enhance the quality of life of the family.

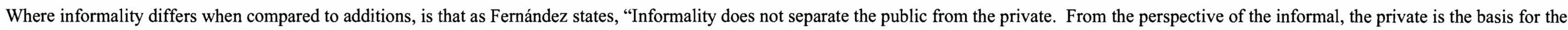

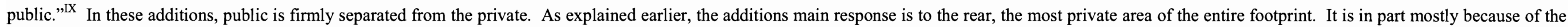

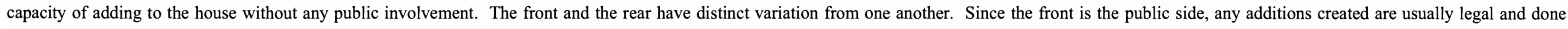

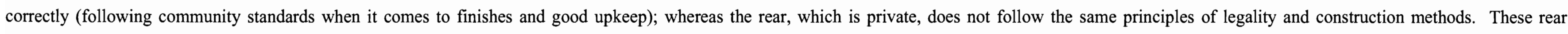

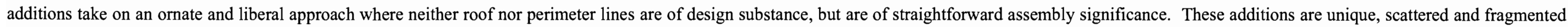
in regards to development and formation.

\footnotetext{
${ }^{\mathrm{VI}}$ Damián J. Fernández, Nation as Incomplete Desire: 166

VII Ibid, 166.

VIII Ibid, 167.

${ }^{\text {IX }}$ Ibid, 167.
} 


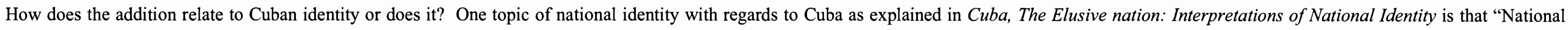

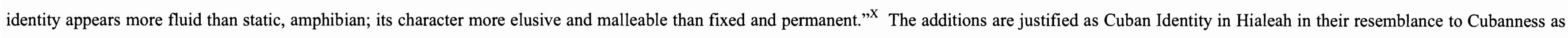

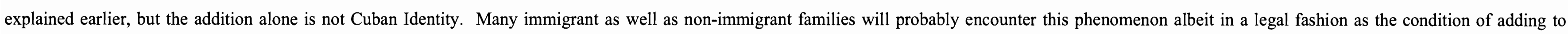

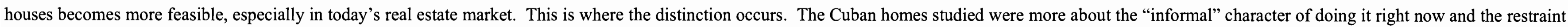
of doing it the right away. Today this process of the spontaneous has not changed, but many times it is halted due to building inspectors and stricter permitting procedures.

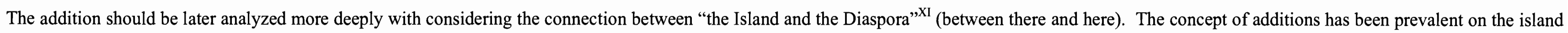

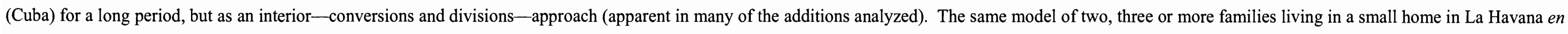
que piso (on what floor), so they can support one another is comparable to houses in Hialeah and this is where the connection is established.

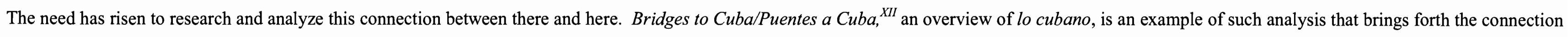

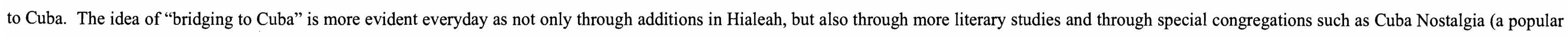
event that puts together several Cuban traditions that are cultural and social to the Cuba of yesterday in one place). What is more common today, is the longing to go back to one's roots- to the ajiaco!

\footnotetext{
${ }^{\mathrm{x}}$ Cámara, M. \& Fernández, D. J. Cuba, The Elusive nation: Interpretations of National Identity: 1.

${ }^{\mathrm{xl}}$ Jorge Duany, Reconstructing Cubanness: Changing Discourses of National Identity on the Island and in the Diaspora During the Twentieth Century: 21.

XII Ibid, 44.
} 


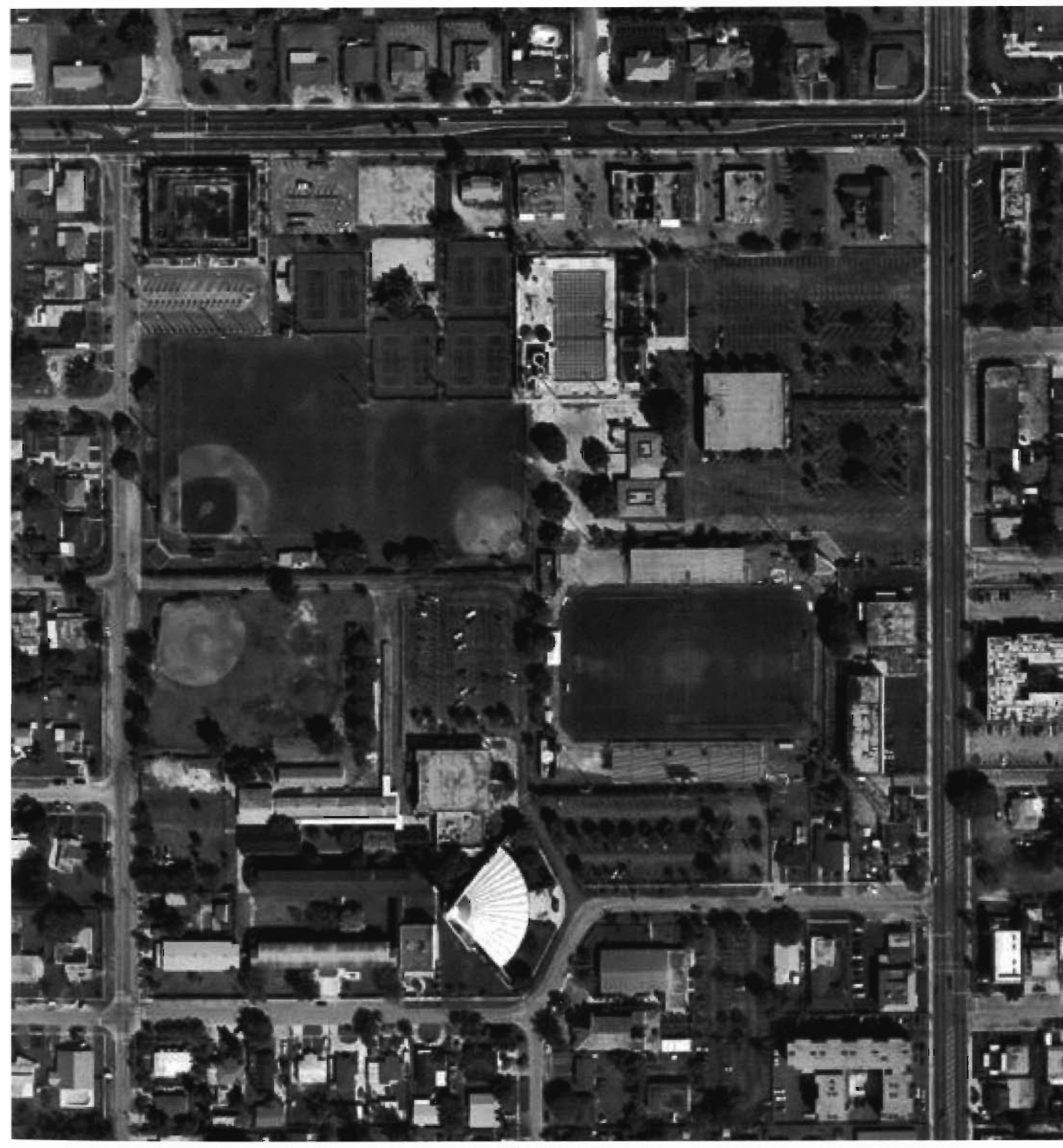

Fig. 12 Milander Park Aerial

How do we make the private, public? How do we bring the rear to the front? The idea is to bring light on this thesis by proposing an addition to a public (civic) property in Hialeah. Hialeah's abundance of parks and recreation areas (that are constantly utilized by the residents-young to old) made the decision on where to locate this addition a simple one. Henry L. Milander Park, located at 4700 Palm Avenue, is the city's largest and most important park consisting of a library, an auditorium, an olympic size pool, a recreation building, a football stadium, and baseball fields. Originally, the Milander Auditorium was an AMP Grocery (Food) Store and before 1959, it became Municipal Auditorium where it was mostly used as a recreation area for kids as well as an auditorium. In 1964, the park's name was changed from Municipal park to Henry L. Milander Park (Henry L. Milander was also the mayor at this time). Soon after (November 1964) the John F. Kennedy Library designed by Rueben Schneider, Hialeah's Architect, broke ground; then was completed and dedicated on July 10, $1965 .^{\text {XIII }}$

The concept is to propose an expansion to the John F. Kennedy Library using the same methods of connections as expressed in the additions to encompass a program that will illustrate and convey an understanding of not only the history of Hialeah, but the history of the residents; from the founding members (pioneer aviator Glenn Curtiss and Missouri cattleman James H. Bright) to the latest Cuban immigrants (los balseros-the rafters). The program consists of:

- Exterior and interior gallery space to highlight yesterday and today's accomplishments through art, music and the media

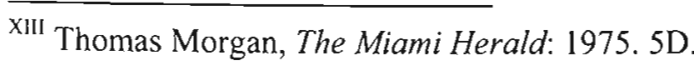


- Exterior seating area similar to porches and the ability to convert to more interior space

- Multiple computer stations for the development, research and connection with the "there and here"

- Multiple reading and study areas needed to update the capacity of the library to today's standard with respect to the city's population

The materials for this new addition will be comparative to the same materials used in the additions that were examined, but the one major difference is that the library addition will be all glass, instead of solid

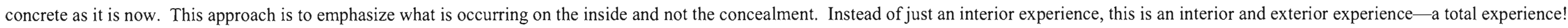

Architectural expression should not be perceived as a cohesive sum of all parts through the external physical, but as a series of fragments that come together in time articulating a sense of unity only through the interrelation of space. This interrelation of space becomes unique only through the actual experience and not through the just visual. The experience is more significant than the illustration.

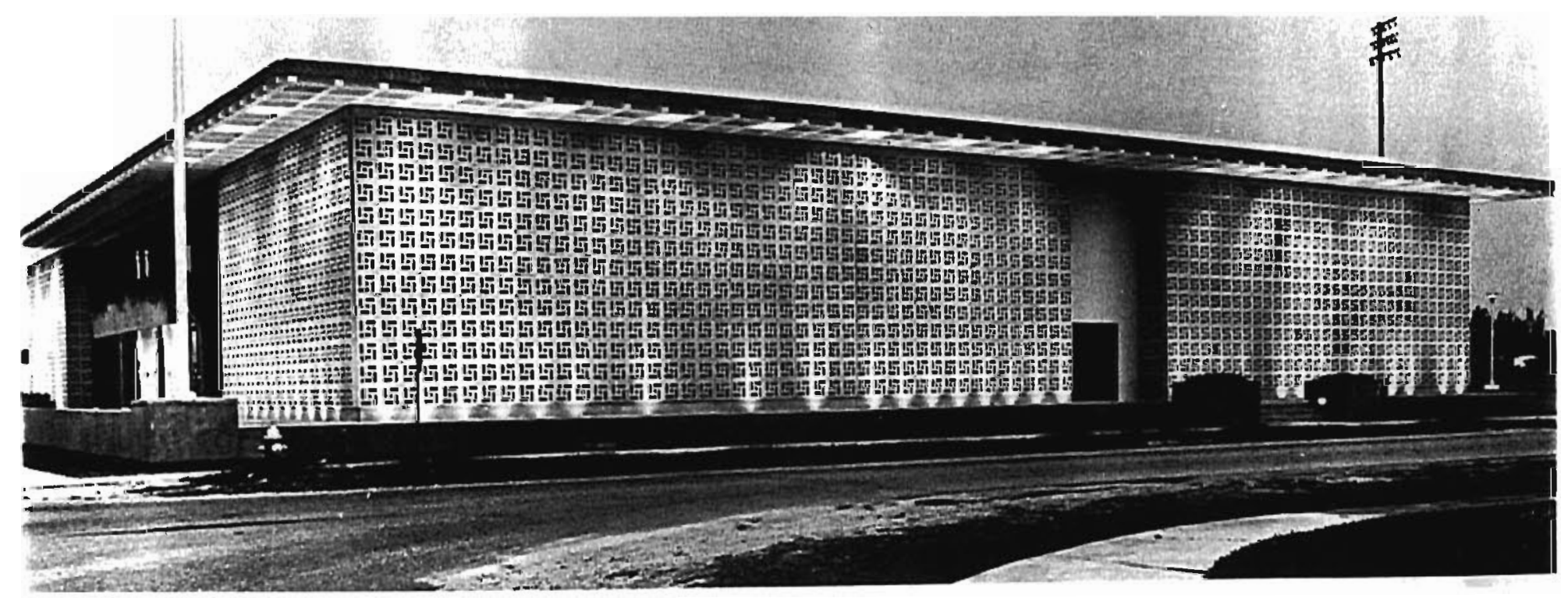

Fig. 13 John F. Kennedy Library, 1965 


\section{LIST OF REFERENCES}

Arboleya, Jesús. Havana-Miami: The U.S.-Cuba migration conflict. Australia: Ocean Press, 1996. Florida International University E 184 c97 a74 1996

Armbruster, Ann. The Life and Times of Miami Beach. New York: Alfred A Knopf, Inc., 1995. Florida International University F 319. M6 A76 1995

Boswell, T.D. and Curtis J.R. The Cuban-American Experience. Rowman \& Allanheld Publishers, 1983. Florida International University E 184 C97 B67 1984

Bryce-Laporte, R.S. and Mortimer, D.M., ed. Caribbean Immigration to the United States. Washington, D.C.: Research Institute on Immigration and Ethnic Studies, Smithsonian Institution, 1983 Bucuvalas, Tina, "Little Havana: the Cubanization of Miami’s cultural heritage," CRM, 1997, v.20, n.11, p.54-56, ISSN 1068-4999

Cámara, M. and Fernández, D. Cuba, The Elusive Nation: Interpretations of National Identity. Pre-release version furnished by author, 1999

Chamberlain, Mary, ed. Caribbean Migration: Globalised Identities. London: Routledge, 1998. Florida International University JV $7321 . C 37$ 1998

Croucher, Sheila L. Imagining Miami: Ethnic Politics in a Postmodern World. Charlottesville: University Press of Virginia, 1997. Florida International University F 319. M6 C76 1997

Duany, Jorge. Reconstructing Cubanness: Changing Discourses of National Identity on the Island and in the Diaspora During the Twentieth Century. Pre-release version furnished by author, 1999.

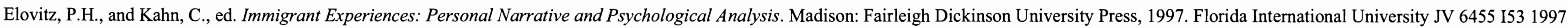

Fernández, Damián J., ed. Cuban Studies Since the Revolution. University Press of Florida, 1992. Florida International University F 1785.5.C83 1992

Fernández, Damián J., Nation as Incomplete Desire. Pre-release version furnished by author, 1999

García, María Cristina. Havana USA: Cuban Exiles and Cuban Americans in South Florida. Berkeley: University California Press, 1996. Florida International University F 320 C97 G37 1996 Greater Miami Convention \& Visitors Bureau. Multicultural Guide. Miami: Greater Miami Convention \& Visitors Bureau, 1998. Florida International University D401/6:M85 1998 Grenier, G.J. and Stepick, Alex, ed. Miami Now! Immigration, Ethnicity, and Social Change. Gainesville: University Press of Florida, 1992. Florida International University F 319 M6 M639 1992 Helgueras, A. and Salmoral, M. El Caribe. Madrid: Anaya, 1998. Florida International University F 2161 L68 1989

Henle, F. \& Knapp, P.E. The Caribbean. New York: The Viking Press, 1957. Florida International University F 2171 H43

Jorge, A.; Suchlicki, J. and Leyva de Varona, A. Cuban Exiles in Florida: Their Presence and Contributions. University of Miami, 1991. Florida International University E 184 C 97 C815 1991

Koulen, Ingrid. ed. What you should know about The Caribbean. Department of Caribbean Studies of the Royal Institute of Linguistics and Anthropology at Leiden, Netherlands, 1982.

Florida International University HN 192.5 W462 1982

Long, Robert Emmet, ed. Immigration to the United States. New York: The H.W. Wilson Company, 1992. Florida International University JV 645515591992

Maingot, Anthony, ed. Trends in U.S.-Caribbean Relations. Thousand Oaks: Sage Publications, 1994. Florida International University F 2178. U6 T74 1994 
Mintz, S. and Price, S., ed. Caribbean Contours. Baltimore: The John Hopkins University Press, 1985. Florida International University F 2169 C365 1985 c.2

Mohl, Raymond A. "Race, Ethnicity, and Urban Politics in the Miami Metropolitan Area," Florida Environmental and Urban Issues, (April 1982): 5

Morgan, Thomas. "Hialeah is 50 and Growing." The Miami Herald, (1975): 1.

Muller, Thomas. Immigrations and the American City. New York: New York University Press, 1993. Florida International University JV 6471 M85 1993

Palmer, Ransford W., ed. In Search of a Better Life: Perspectives on Migration from the Caribbean. New York: Praeger, 1990. Florida International University JV 7321 I5 1990

Palmer, Ransford W., ed. U.S.-Caribbean Relations: Their Impact on Peoples and Culture. Westport: Praeger, 1998. Florida International University F 2169. U6 1998

Pastor, Robert A., ed. Migration and Development in the Caribbean: The Unexplored Connection. Boulder: Westview Press, 1985. Florida International University JV 7321 Z7 E285 1985

Pérez-Firmat, Gustavo. The Cuban Condition. Cmabridge University Press, 1989. Florida International University PQ 7378.P47 1989

Richmond, Marie LaLiberte. Immigrant Adaptation and Family Structure among Cubans in Miami, Florida. New York: Arno Press, 1980. Florida International University F 319 M6 R52 1980 c.2

Santiago, Fabiola. "Hialeah." The Miami Herald, (2000): 4L - 5L.

Sunshine, Catherine A. The Caribbean. Boston. An Epica Publication, 1985. Florida International University F 2183 S94 1985 
APPENDICES 
1. What is your name?

2. What do you do for a living?

1. What was you lanilly bachgound in Cuba?

4. What did your parents do for a living?

5. What year did you come to Hialeah?

6. How long have you lived in Hialeah?

7. Who lives in the household with you?

8. When did they come to Hialeah?

9. Who were the neighbors when you moved in?

10. Have they changed over time?

11. Who are your neighbors now?

12. In which houses do these neighbors live?

13. Were there any events or times when neighbors got together?

14. What changes if any, did you make to the neighborhood or home?

15. What changes did the neighborhood go through?

16. Why did you come to Hialeah?

17. Why did you move?

18. What have you and your family done to Hialeah?

19. How is your house a Cuban home?

20. Were there any additions undertaken to the house?

21. When were they done?

22. What materials did you use?
23. Who helped you with the construction?

24. Who planned out what you needed?

25. Ale theie other tiansturmations to the house or the yard?

26. What would you do to your house if you could?

27. Is there anything that you are missing in Hialeah that you had in Cuba?

28. What do you have in Hialeah that was missing in Cuba?

29. How do use the city of Hialeah?

30. Do you shop in town or do you leave?

31. Do you go to school in Hialeah?

32. Did you go to school in Hialeah?

33. What are your hopes and aspirations for Hialeah?

34. What would you change about Hialeah if you could?

35 . What would you add or eliminate?

36. Is Hialeah beautiful or ugly? In what ways?

37. Do you want to stay in Hialeah or do you want to leave?

38. How do you know when someone else is Cuban? 


\begin{tabular}{|c|c|}
\hline 1. Anonymous & 20. Yes \\
\hline 2. Construction worker & 21. Since we moved, year after year and still making changes \\
\hline 3. Havana & 22. Concrete, wood, whatever we could get \\
\hline 4. Agriculture & 23. My son drew the plans and with the help of family and neighbors made changes with permits \\
\hline 5. 1980 , the Mariel Boatlift & 24. My son and I \\
\hline 6. 20 years & 25. That's it really, but I'm sure there will be more \\
\hline $\begin{array}{l}\text { 7. } 5 \text { young adults ( } 3 \text { are my kids and two others are my nephew and his wife- - they were married } \\
\text { before leaving Cuba in order to be able to come to the U.S.) }\end{array}$ & $\begin{array}{l}\text { 26. Remodel kitchen, new tile } \\
\text { 27. Places to meet, night activities }\end{array}$ \\
\hline $\begin{array}{l}\text { 8. } 2 \text { sons and } 1 \text { daughter (1980); nephew and wife (1999) } \\
\text { 9. Mostly Cubans and just one American that still lives across the street }\end{array}$ & $\begin{array}{l}\text { 28. A/C, more food, better cars } \\
\text { 29. We all have worked or gone to school in Hialeah }\end{array}$ \\
\hline $\begin{array}{l}\text { 10. Most have stayed, very few have moved out except for their sons, daughters } \\
\text { 11. Same ones (mostly Cubans-if not all) }\end{array}$ & 30. I shop for everything here in Hialeah \\
\hline 12. Same ones & $\begin{array}{l}\text { 31. Yes, all the kids grew up going to the parks especially in the summer time } \\
\text { 32. No, but all the kids went to school in Hialeah }\end{array}$ \\
\hline $\begin{array}{l}\text { 13. Sometimes to see the fireworks on the } 4^{\text {th }} \text { of July and also for quinceañeras (sweet fifteens), } \\
\text { birthdays, New Years, when someone needs help...I'm a construction worker, the neighbor two } \\
\text { houses down is an electrician, so we help each other out whenever needed }\end{array}$ & $\begin{array}{l}\text { 33. We wish they would open up the sidewalks (make them wider) for walking at night and more } \\
\text { night activities. In Cuba the portal was used at night to watch TV because very few people in the } \\
\text { neighborhood had TVs. Everyone would sit on the portal and look inside where the TV was }\end{array}$ \\
\hline $\begin{array}{l}\text { 14. There has been many changes, alterations and additions done just to this house as well as other } \\
\text { houses around this neighborhood - all for the better of course! }\end{array}$ & $\begin{array}{l}\text { located. Also no crimes were committed because everyone was always outside looking and } \\
\text { watching if any strange people was lingering around the neighborhood }\end{array}$ \\
\hline 15. Just the ones to the houses like new windows, paint, pools...the neighborhood is more clean & 34. The delinquency, robberies, security \\
\hline $\begin{array}{l}\text { 16. Opportunity to work and mejorar better ourselves since we realized that we were not going back } \\
\text { to Cuba, closer to jobs, and the language (Spanish) }\end{array}$ & 35. Night Activities, wider sidewalks \\
\hline 17. To leave the Castro Regime & 36. It's beautiful and very clean \\
\hline $\begin{array}{l}\text { 18. Helped make Hialeah what it is today } \\
\text { 19. What we eat, cook, music, what we build portales }\end{array}$ & $\begin{array}{l}\text { 38. By their gestures, features (physical), their cars have the saints and the Cuban flag on the } \\
\text { dashboard or hanging from the rear view mirror. }\end{array}$ \\
\hline
\end{tabular}




\section{Case Study \#2}

\begin{tabular}{|c|c|}
\hline 1. Anonymous & 22. Concrete, wood, whatever we found \\
\hline 2. Contractor & 23. The family \\
\hline 3. Miramar & 24. I did, with no permits \\
\hline 4. Contractor & 25. Made rooms into "efficiencies" \\
\hline 5. 1980 & 26. Remodel everything, new kitchen, new tile \\
\hline 6. 20 years & 27. The neighbor interaction \\
\hline 7. Himself, 5 other adults & 28. Everything (money) \\
\hline 8. At different times (Mariel and balseros) & 29. I live here \\
\hline 9. Mostly Cubans and the same ones still today & 30. I shop for everything here in Hialeah \\
\hline 10. Most have stayed, very few have moved out except for their sons, daughters & 31. Not really \\
\hline 11. Same ones & 32. Yes, high school \\
\hline 12. Same ones & 33. Less Traffic \\
\hline 13. Not really, everyone stays to themselves & 34. The delinquency, robberies \\
\hline 14. Painted and additions & 35. Same as 34 \\
\hline 15. Nicer homes since Cubans moved in & 36. It's beautiful and very clean \\
\hline 16. Work & 37. Stay, but if I had the money I would like to move to Miramar or Pembroke Pines \\
\hline 17. Same as 16 & 38. Cubans are chusma (loud, bad words) \\
\hline \multicolumn{2}{|l|}{ 18. Nothing but work } \\
\hline \multicolumn{2}{|l|}{ 19. What we eat, cook, music, everything is Spanish (the TV, news, speak) } \\
\hline 20. Yes & \\
\hline 21. As soon as we moved in & \\
\hline
\end{tabular}




\begin{tabular}{|c|c|}
\hline 1. Anonymous & 22. Concrete, wood, whatever we found \\
\hline 2. Contractor & 23. The Family \\
\hline 3. Miramar & 24. I did, with no permits \\
\hline 4. Agricultural & 25. Made rooms into two "efficiencies" \\
\hline 5. 1980 & 26. Remodel everything, new kitchen, new tile, it never ends \\
\hline 6. 20 years & 27. Too much traffic \\
\hline 7. Himself, wife and 3 other elderly adults & 28. Money and food \\
\hline 8. At different times (Mariel and visa) & 29. I live here and have worked here \\
\hline 9. Mostly Cubans and the same ones still today & 30. I shop for everything here \\
\hline 10. Most have stayed, very few have moved out & 31. Not really \\
\hline 11. Same ones & 32. No, but my kids did \\
\hline 12. Same ones & 33. Less traffic \\
\hline 13. Not really, everyone stays to themselves except for my next door neighbor & 34. The delinquency, robberies, THE MAYOR! \\
\hline 14. Painted and remodel interior and utility in the back & 35. Same as 34 \\
\hline 15. Nicer homes since Cubans moved in & 36. It's beautiful and very clean and nice houses \\
\hline 16. Cheap houses with big backyard & 37. Stay, I don't want to go anywhere \\
\hline 17. Same as 16 & 38. The way they dress and speak..it's easy! \\
\hline \multicolumn{2}{|l|}{ 18. Nothing, maybe made some houses that I worked on nicer } \\
\hline \multicolumn{2}{|l|}{ 19. What we eat, cook, it's who we are } \\
\hline \multicolumn{2}{|l|}{ 20. Yes } \\
\hline 21. As soon as we moved in & \\
\hline
\end{tabular}




\section{Case Study \#4}

\begin{tabular}{|c|c|}
\hline 1. Anonymous & 22. Regular construction materials \\
\hline 2. Lunch Truck Driver & 23. Friends \\
\hline 3. Guantánamo & 24. Me and my friends \\
\hline 4. Businessman & 25. No, just keep upgrading every few years \\
\hline 5. 1972 & 26. No \\
\hline 6. 28 years & 27. I had nothing in Cuba \\
\hline 7. Himself, wife and son, wife and their 2 kids & 28. Money, money, money \\
\hline 8. Left to Puerto Rico after Fidel took over and then came to Hialeah in 1972 & 29. I live here \\
\hline 9. All Americans & 30. I shop for everything here \\
\hline 10. Definitely, most have moved out & 31. My son used to... he played baseball. \\
\hline 11. All kinds, Cubans, Chinese, Central Americans, one maybe two Americans & 32. No, but my kids did \\
\hline 12. All around & 33. Less traffic, better drivers \\
\hline 13. Never, not even with the lake in the back, I do with my family (roast a pig) & 34. The delinquency, robberies \\
\hline 14. Painted and remodel everything, and still remodeling & 35. Same as 34 \\
\hline 15. Different people, different paint jobs, same house & 36. It's beautiful and very clean and nice houses \\
\hline 16. Cheap houses with big backyard and a lake, close to school for my kids also & 37. Stay, I don't want to go anywhere \\
\hline 17. Same as 16 & 38. The way they speak, they have a specific tone and language seen nowhere else. \\
\hline \multicolumn{2}{|l|}{ 18. Nothing } \\
\hline \multicolumn{2}{|l|}{ 19. What we eat, cook, it's who we are } \\
\hline 20. Yes a few, a "Florida room", utility, several things & \\
\hline 21. A little after we moved in & \\
\hline
\end{tabular}


Case Study \#5

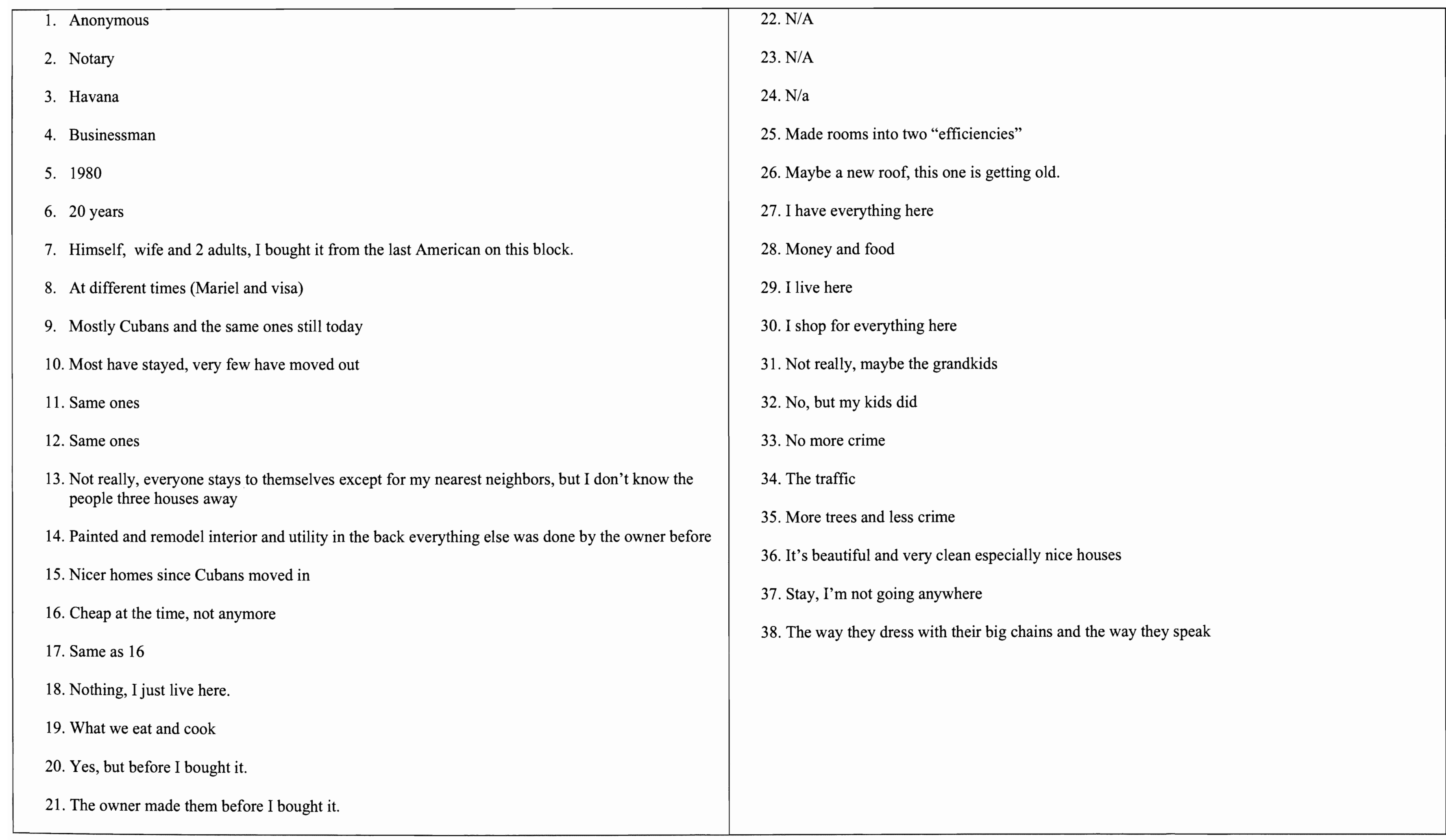


Case Study \#6

\begin{tabular}{|c|c|}
\hline 1. Anonymous & 22. N/A \\
\hline 2. House painter & 23. N/A \\
\hline 3. Guantanamo & 24. N/A \\
\hline 4. Businessman & 25. Made rooms into "efficiencies" \\
\hline 5. 1990 & 26. Remodel everything, new kitchen, new tile, new paint (soon) \\
\hline 6. 10 years & 27. The neighbor interaction \\
\hline 7. Himself, wife and two adults & 28. Everything, I had nothing in Cuba \\
\hline 8. At different times (visa and balseros) & 29. I live here and work sometimes painting Hialeah houses \\
\hline 9. Mostly Cubans and the same ones still today & 30. I shop for everything here \\
\hline 10. Most have stayed, very few have moved out & 31. No \\
\hline 11. Same ones & 32. No \\
\hline 12. Same ones & 33. For more Cubans to come to Hialeah \\
\hline 13. Not really, except with my brother and lives across the street & 34. The delinquency, robberies \\
\hline 14. Painted and made two rooms into "efficiencies" & 35. Same as 34 \\
\hline 15. None really, it looks the same to me & 36. It's beautiful, I love it here \\
\hline 16. To be close to my family, they are all here & 37. Stay, I'm not going anywhere \\
\hline 17. I never moved, ever since I arrived from Cuba, I live in Hialeah & 38. The chusmerías (loud, bad words)...I love it! \\
\hline \multicolumn{2}{|l|}{ 18. Nothing but work, work, work } \\
\hline \multicolumn{2}{|c|}{ 19. What we eat, cook, music, everything is in Spanish, we don't speak English } \\
\hline \multicolumn{2}{|l|}{ 20. Yes, but before I bought it } \\
\hline 21. Before I bought it & \\
\hline
\end{tabular}


Case Study \#7

\begin{tabular}{|c|c|}
\hline 1. Anonymous & 22. Concrete, wood, what looked good at that time \\
\hline 2. Handyman & 23. A contractor \\
\hline 3. Marianao & 24. The contractor, everything was done with a permit \\
\hline 4. Viandero (sold grocery items like vegetables, fruits, beans, etc.) & 25. Just additions and transformations \\
\hline 5. 1980 & 26. Clean up the backyard, it's full of junk \\
\hline 6. 20 years & 27. Family. I miss my family. \\
\hline 7. Himself, wife and one couple with a child & 28. Everything (I didn't have anything in Cuba) \\
\hline 8. Visa & 29. I work mostly in Hialeah \\
\hline 9. Mostly Cubans and the same ones still today & 30. I shop for everything here \\
\hline 10. Most have stayed, very few have moved out except for their sons, daughters & 31. Sometimes \\
\hline 11. Same ones (mostly Cubans-if not all) & 32. No, all the kids that have moved out, did though \\
\hline 12. Same ones & 33. I don't like the mayor, but I he's done a lot. \\
\hline 13. Not really, everyone stayed to themselves except when I go to church & 34. The delinquency, robberies \\
\hline 14. Painted, enclosed areas, two addition and storage & 35. Same as 34 \\
\hline 15. None really everyone just makes their houses more beautiful & 36. It's beautiful and very clean and the city government is always making it better \\
\hline 16. Some of my family lives here & 37. Stay, but if I had the money I would like to move to Pembroke Pines \\
\hline 17. Same as 16 & 38. Their mannerisms, the way they express themselves and the way they talk \\
\hline \multicolumn{2}{|l|}{ 18. Nothing, I do a lot with the church group though } \\
\hline \multicolumn{2}{|l|}{ 19. What we eat, cook, music, everything about us is Cuban } \\
\hline \multicolumn{2}{|l|}{ 20. Yes } \\
\hline 21. 1-2 years after moving in & \\
\hline
\end{tabular}




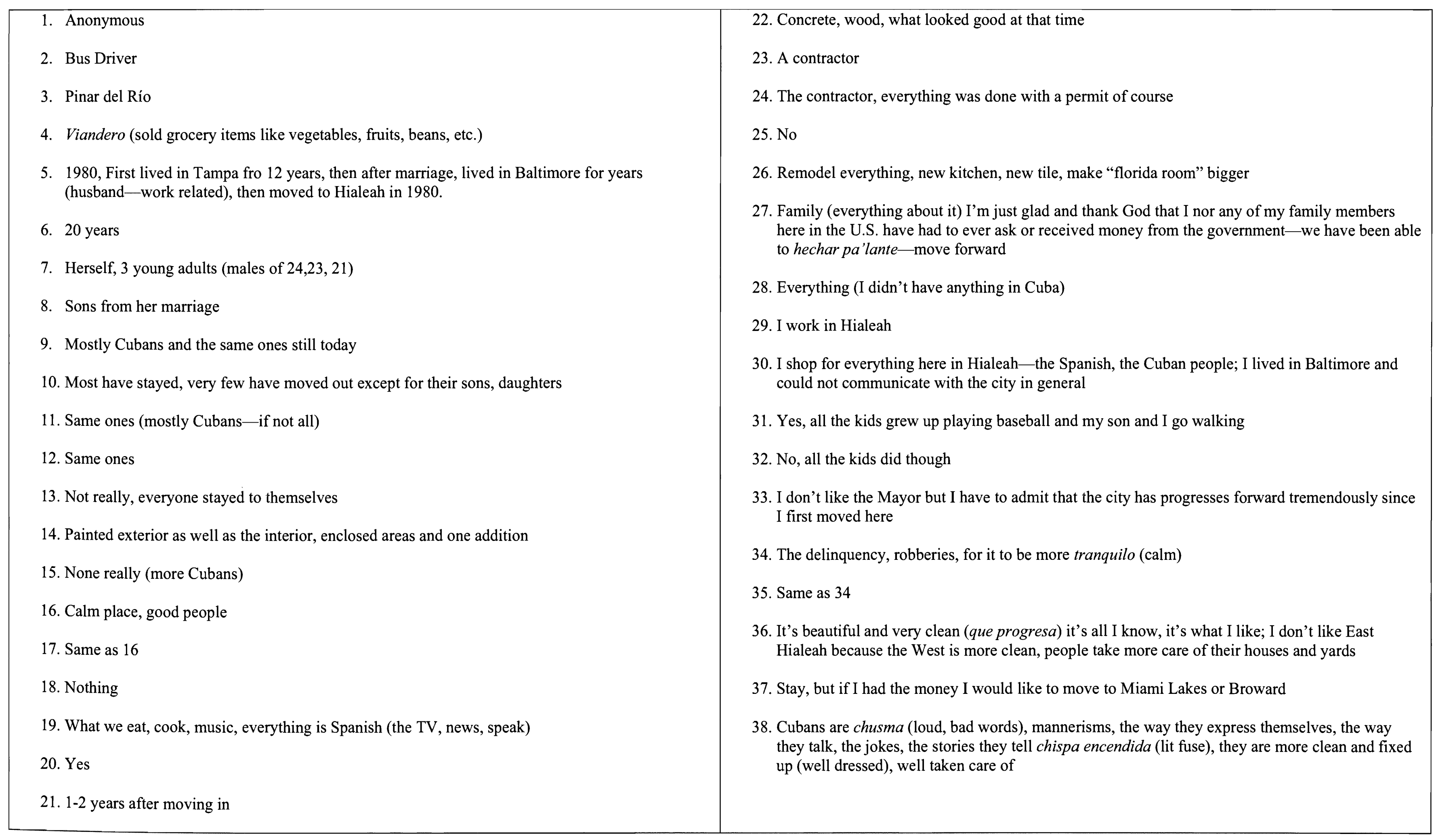




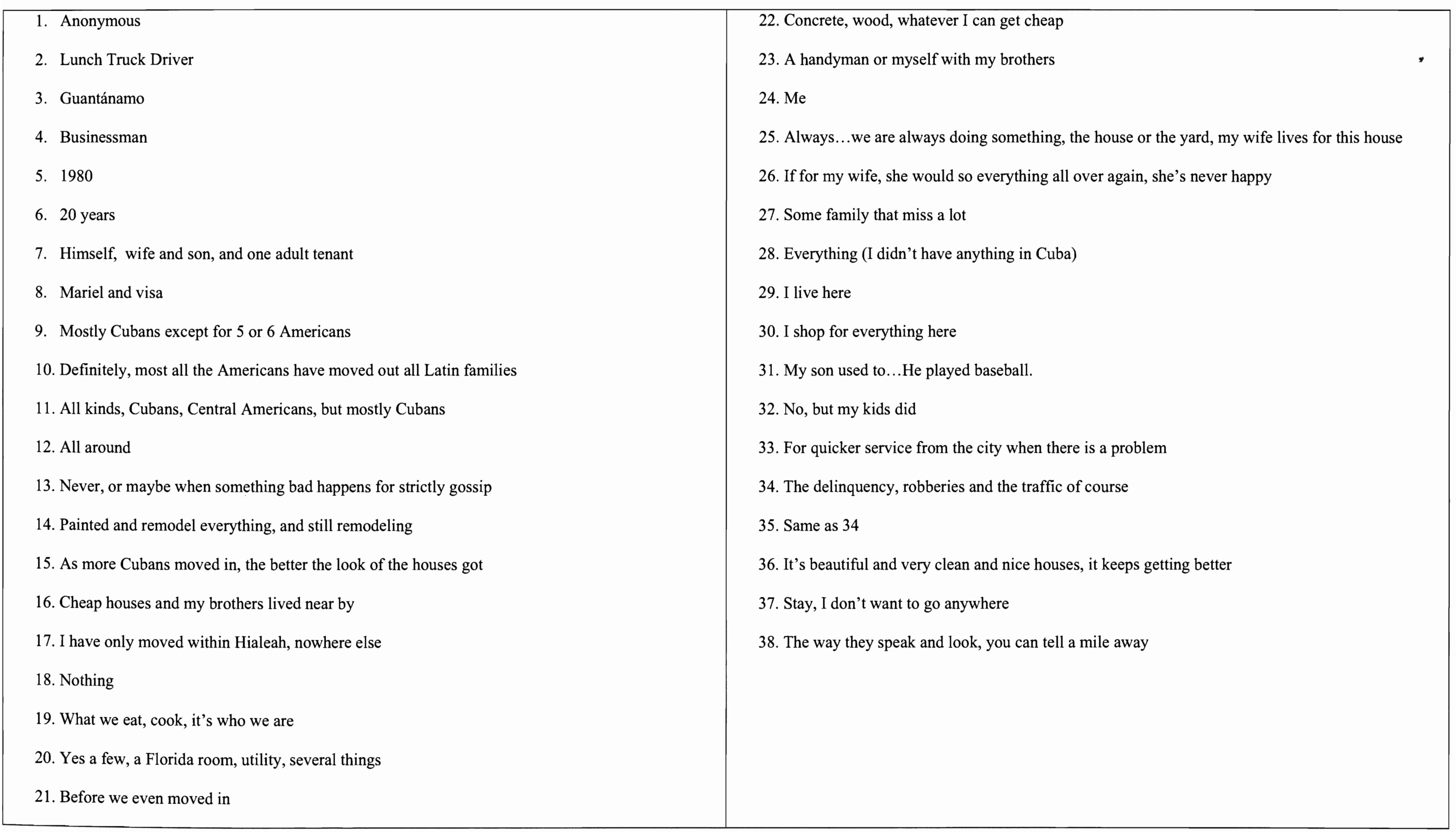




\begin{tabular}{|c|c|}
\hline 1. Anonymous & 22. Whatever was available \\
\hline 2. Handyman & 23. Friends \\
\hline 3. Pinar del Río & 24. Me and my friends \\
\hline 4. Mechanic & 25. No, it's been like this for awhile \\
\hline 5. 1980 & 26. Maybe move out \\
\hline 6. 20 years & 27. I had nothing in Cuba and I have everything here \\
\hline 7. Himself, wife and son, mother and father, couple and their 2 kids & 28. Money, money, money \\
\hline 8. I first lived in New Jersey and then came to Hialeah in 1980 & 29. I live here and I work in Miami \\
\hline 9. All Cubans & 30. I shop for everything here \\
\hline 10. Nothing except more traffic & 31. No not even my sons \\
\hline 11. Mostly the same ones & 32. No, but my kids did \\
\hline 12. Same ones & 33. For less traffic, better drivers, and less crime \\
\hline 13. Never, this street is too busy for anything & 34. The delinquency, robberies \\
\hline 14. Painted and remodel everything, and a big driveway (too may cars) & 35. Same as 34 \\
\hline 15. The traffic mostly & 36. It's beautiful with nice houses here and there \\
\hline 16. Cheap houses, I hated the cold weather & 37. Stay, I can't go anywhere; I can't afford it \\
\hline 17. Same as 16 & 38. The way they dress and speak (their gesture) \\
\hline \multicolumn{2}{|l|}{ 18. Nothing } \\
\hline \multicolumn{2}{|c|}{ 19. What we eat, cook, my parents don't speak English, so it's still like the old days } \\
\hline 20. Yes a few big ones a Florida room, an apartment for my parents whi & \\
\hline 21. Some time after we moved in & \\
\hline
\end{tabular}


Case Study \#11

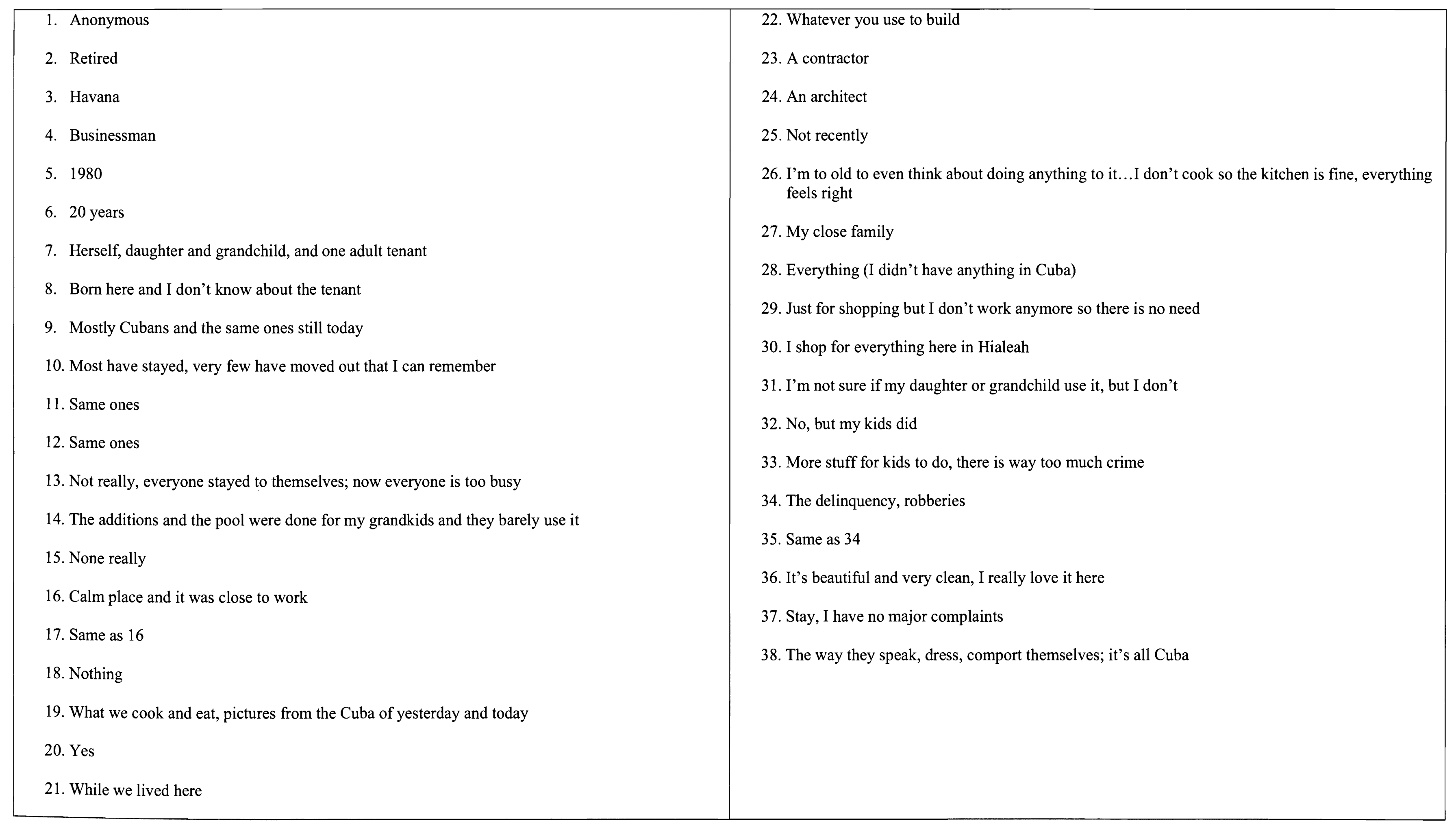


Case Study \#12

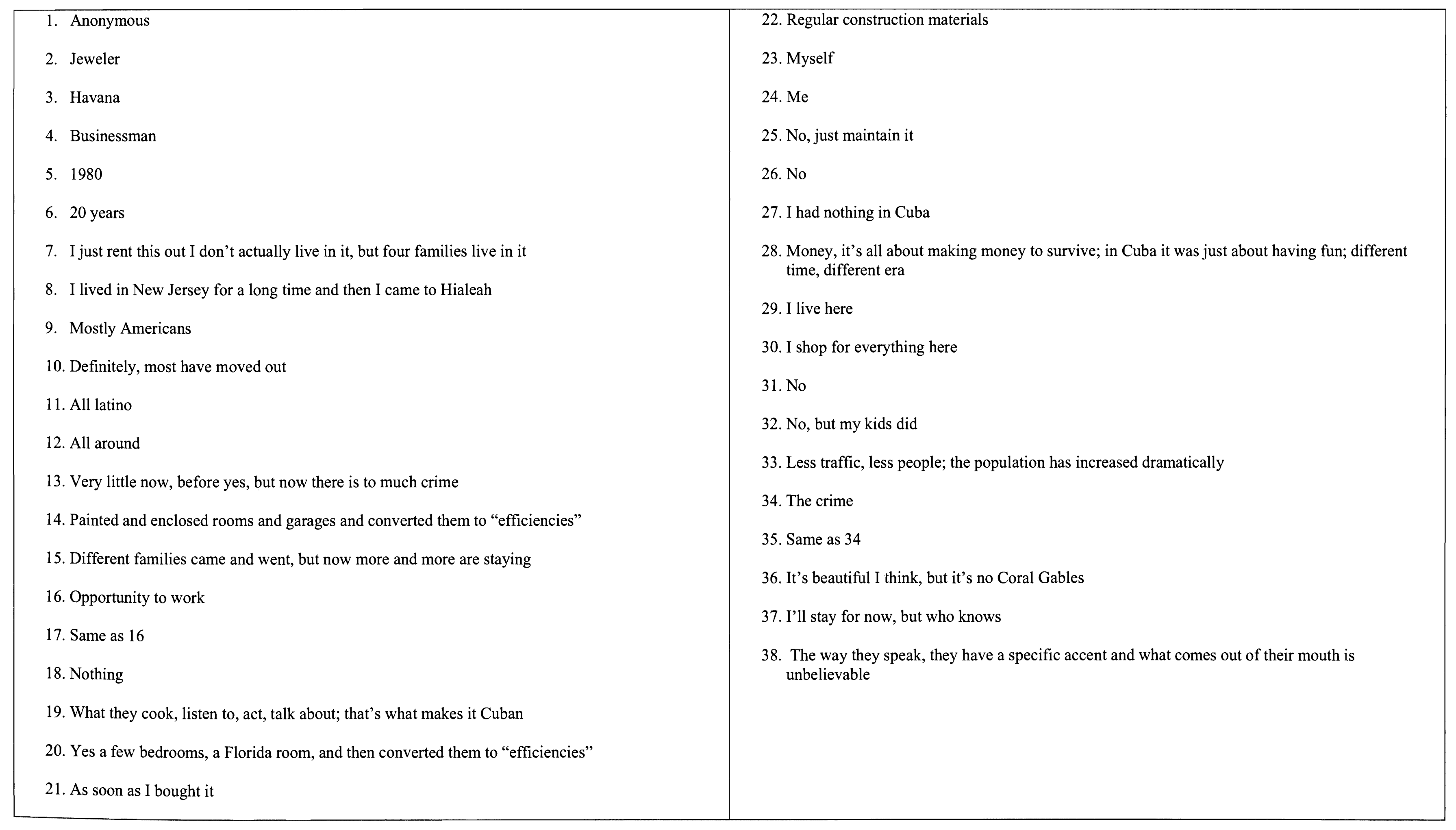



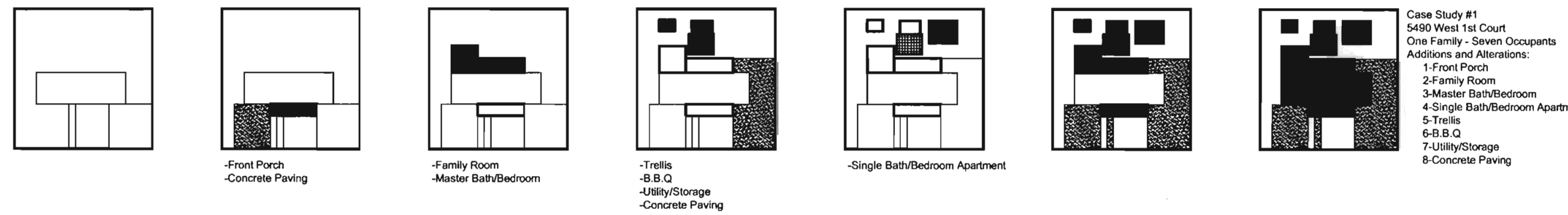

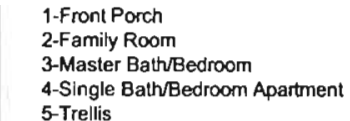

6-B.B.QQ
7-Unitity/Storage
B-Concrete Paving
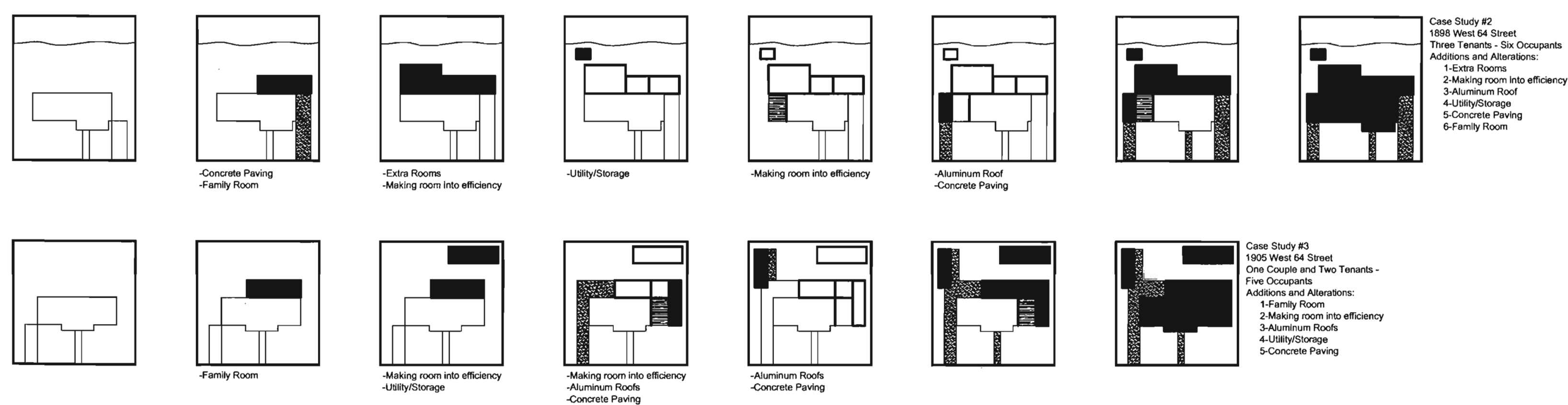

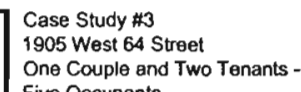
Five Occupants
Addhions and Alteratons:
1 1Fandy

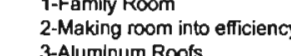
3.-Aumlinum Rools
4-utillystorages
5-concrele Paving
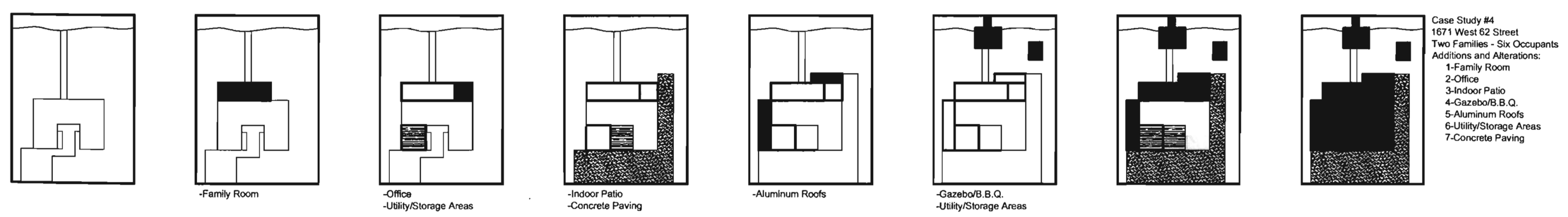

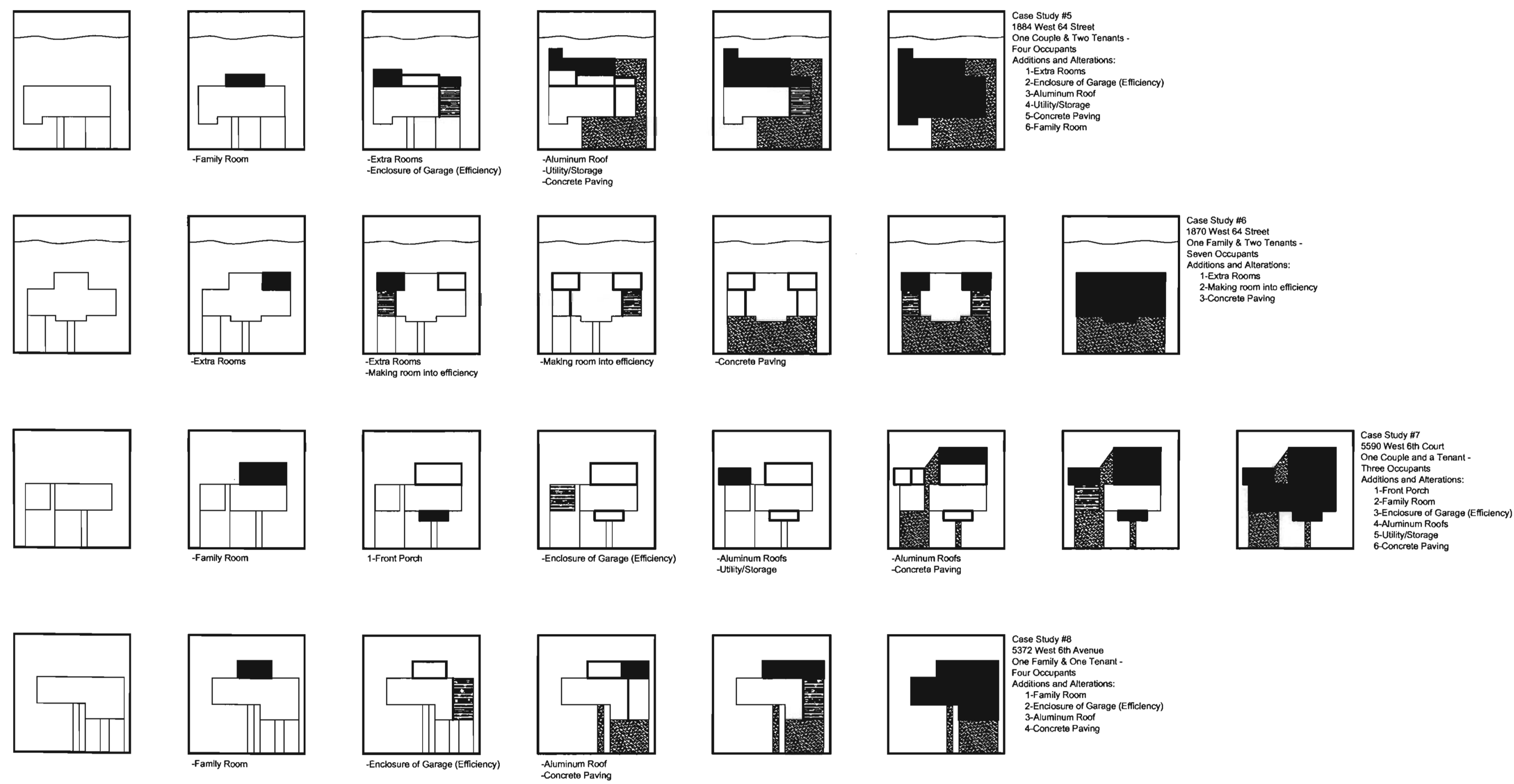

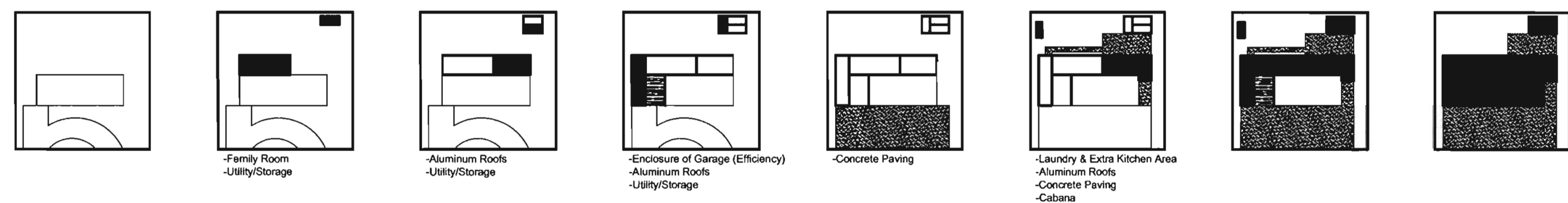

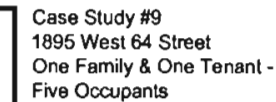

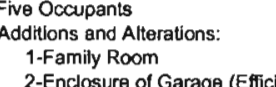

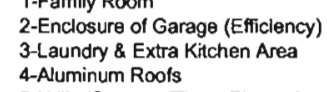

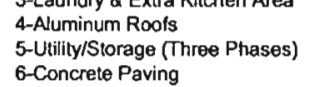
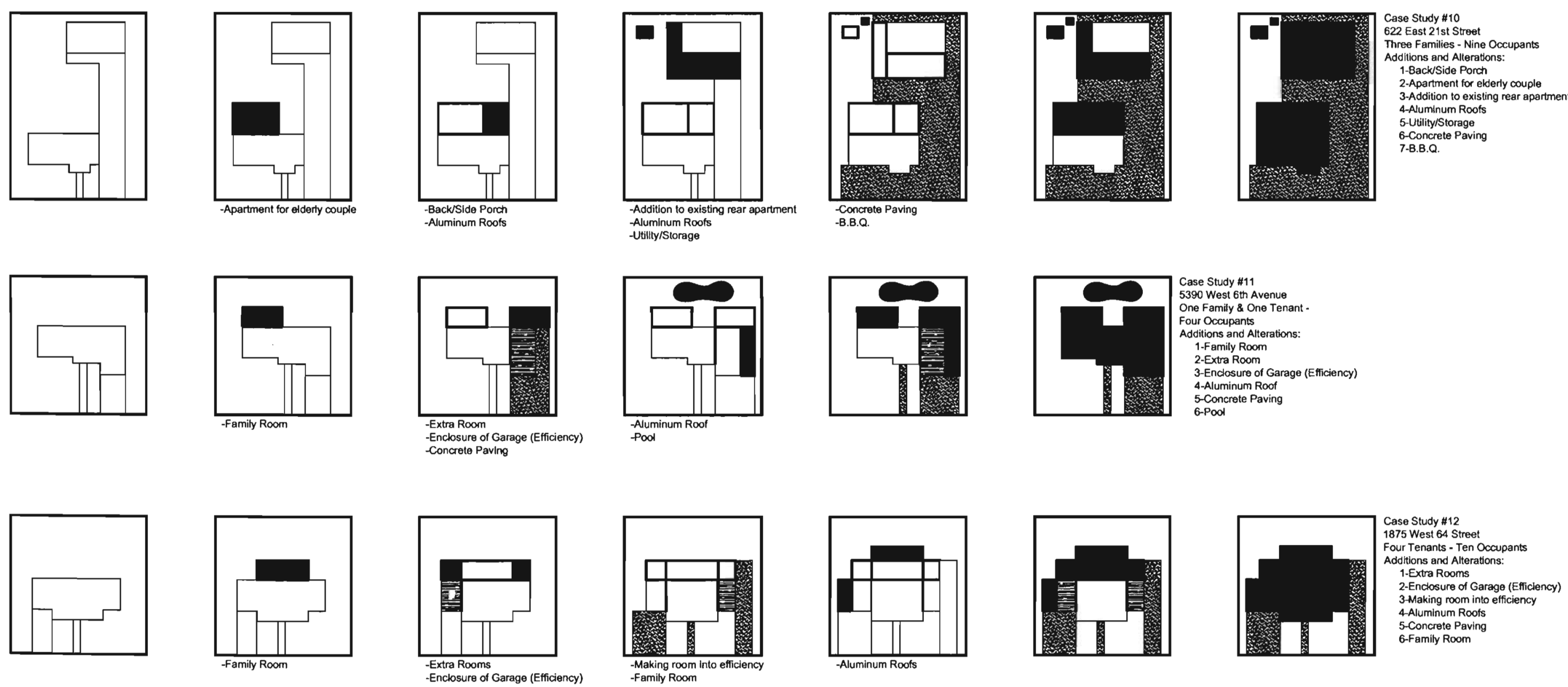


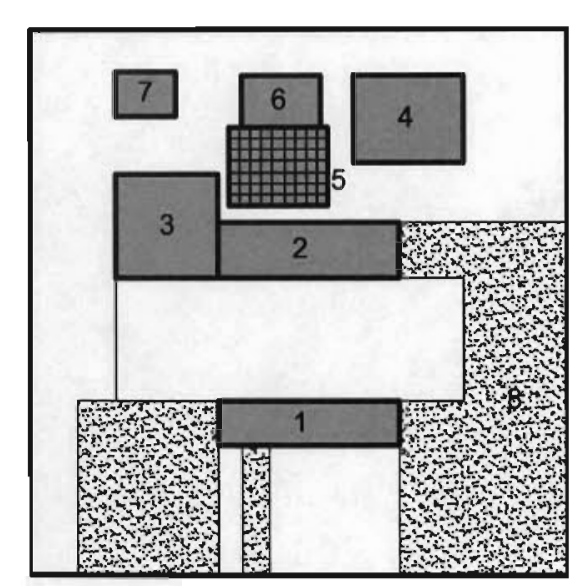

Case Study \#1
5490 West 11 Court
1980 - Hialeah Resident One Family - Seven Occupants

Additions and Alterations:

2-Family Room

2-Mamily Room

4-Single Bath/Bedroom Apartmen

5-Trellis

7-Utility/Storage

8-Concrete Paving
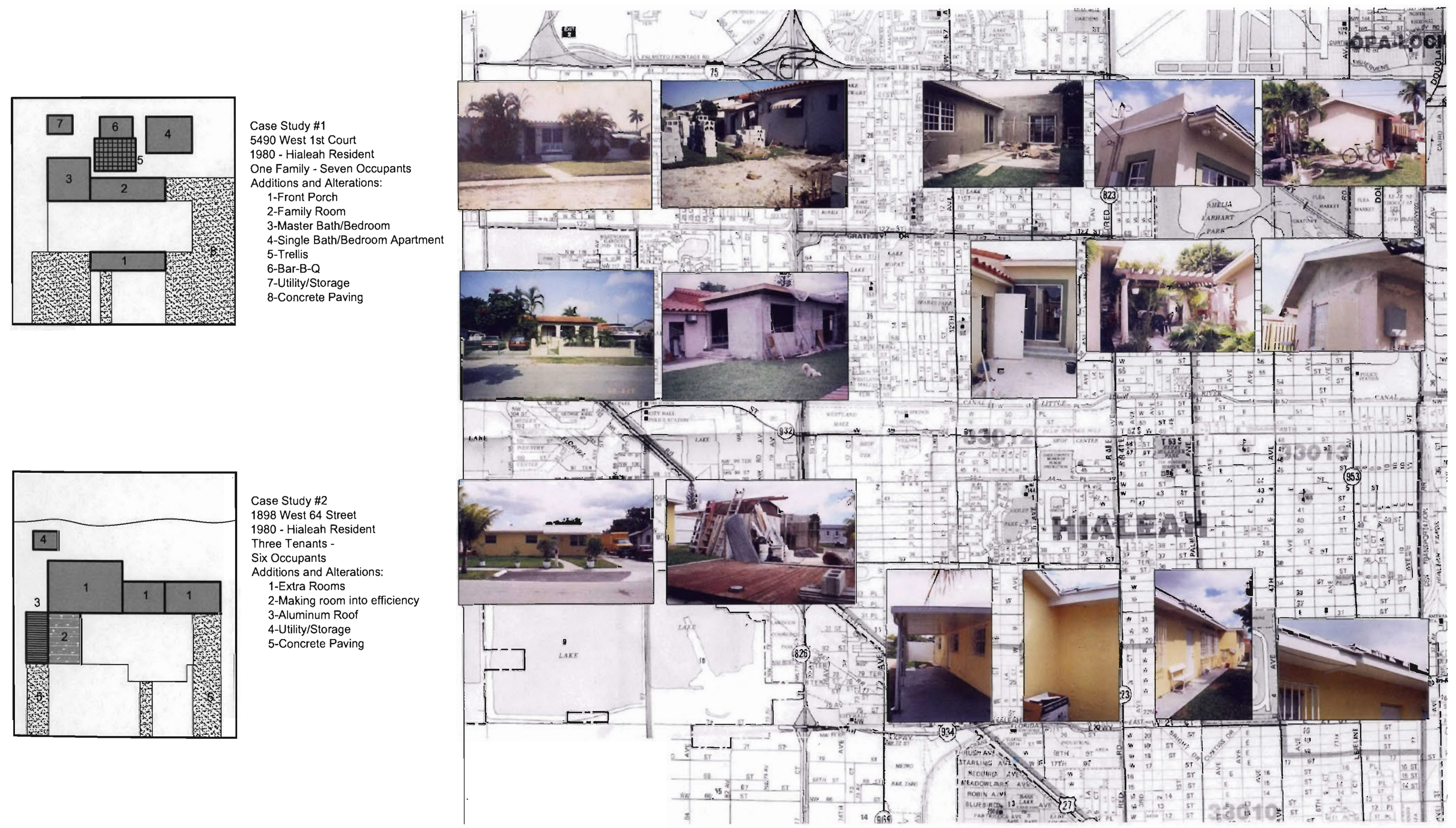


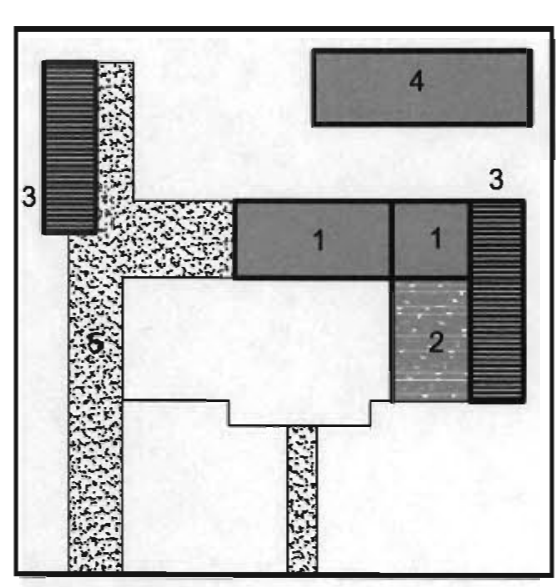

Case Study \#3

1980 - Hialeah Resident

One Couple and Two Tenants

Additions and Alterations

1-Extra Rooms

2-Making room into efficiency

3-Aluminum Roofs

4-Utility/Storage

5-Concrete Paving

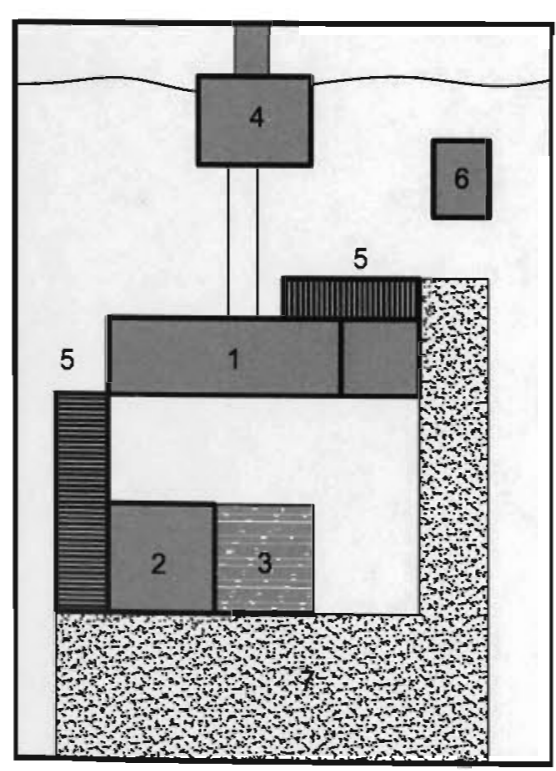

Case Study \#4

1671 West 62 Street
1974 - Hialeah Reside

1974 - Hialeah Resic
Two Families -

Six Occupants

1-Family Room

2-Office

3-Indoor Patio

5-Gazebo

6-Utumilityum Roofs

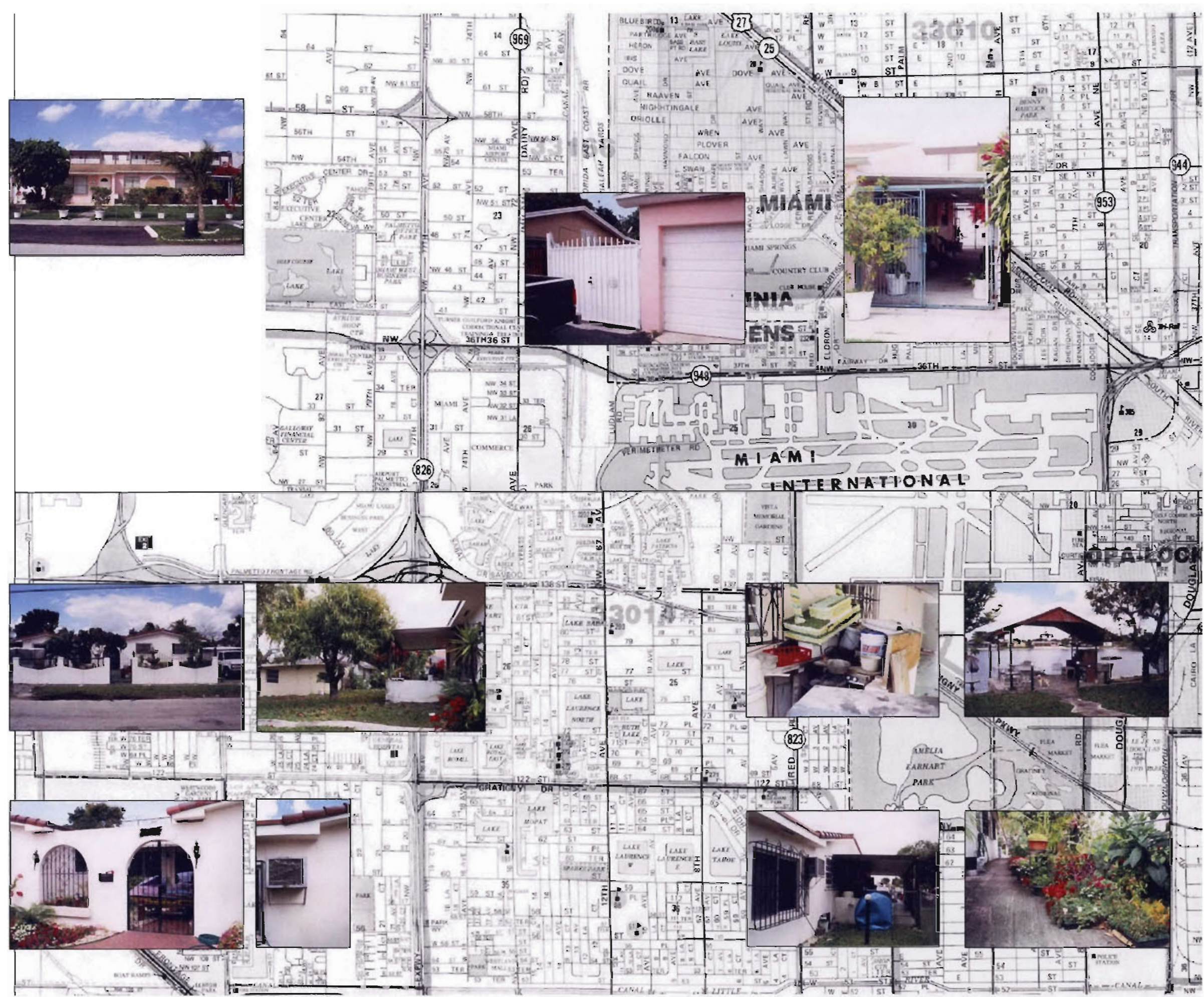




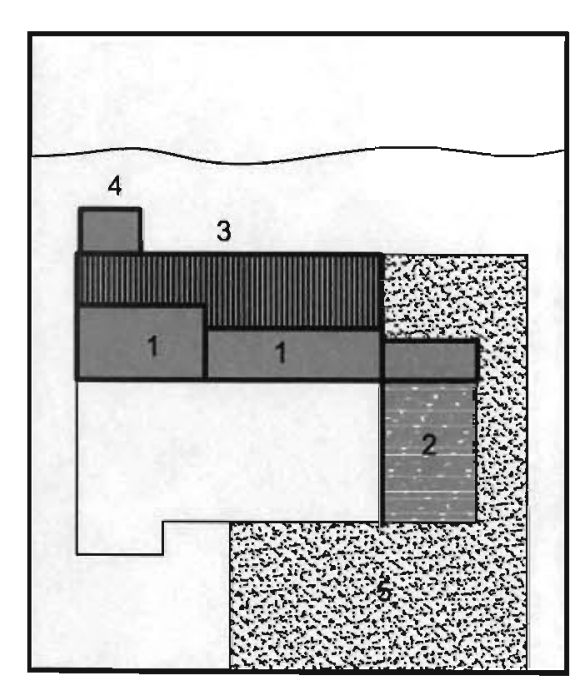

Case Study \#5
1884 West 64 Stree

1980 - Hialeah Resident

One Couple \& Two Tenants -

Four Occupants

Ad-Extra Rooms
Aditions and Alterations:

2-Enclosure of Garage (Efficiency)

3-Aluminum Roof

4-Utility/Storage

5-Concrete Paving
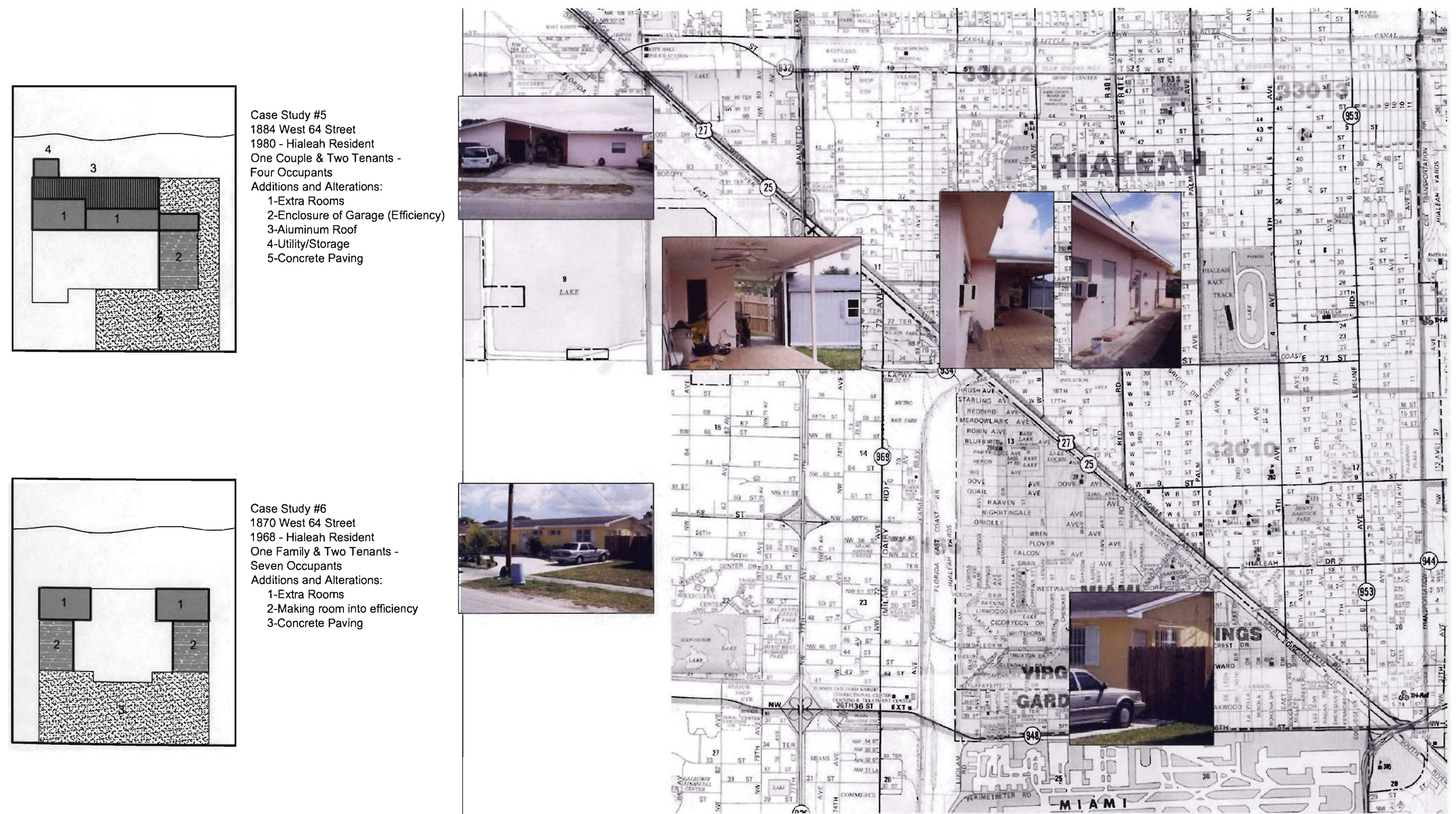


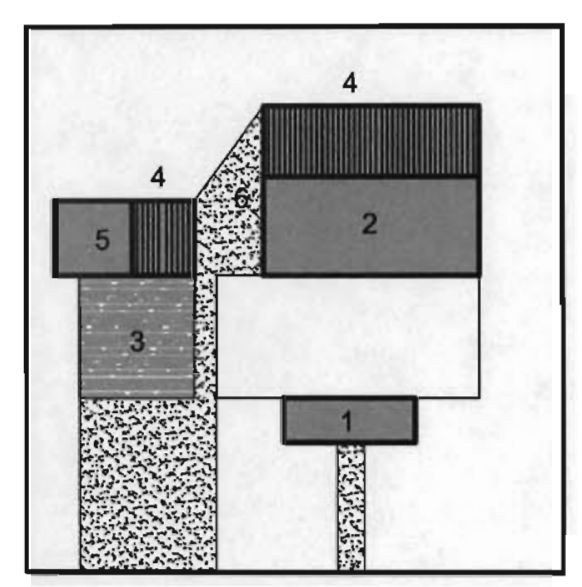

Case Study \#7

5590 West 6th Court

1971 - Hialeah Resident
One Couple and a Tenant -

Three Occupants

Additions and Alterations:

2-Family Room

3-Enclosure of Garage (Efficiency)

4-Aluminum Roofs

6-Concrete Paving
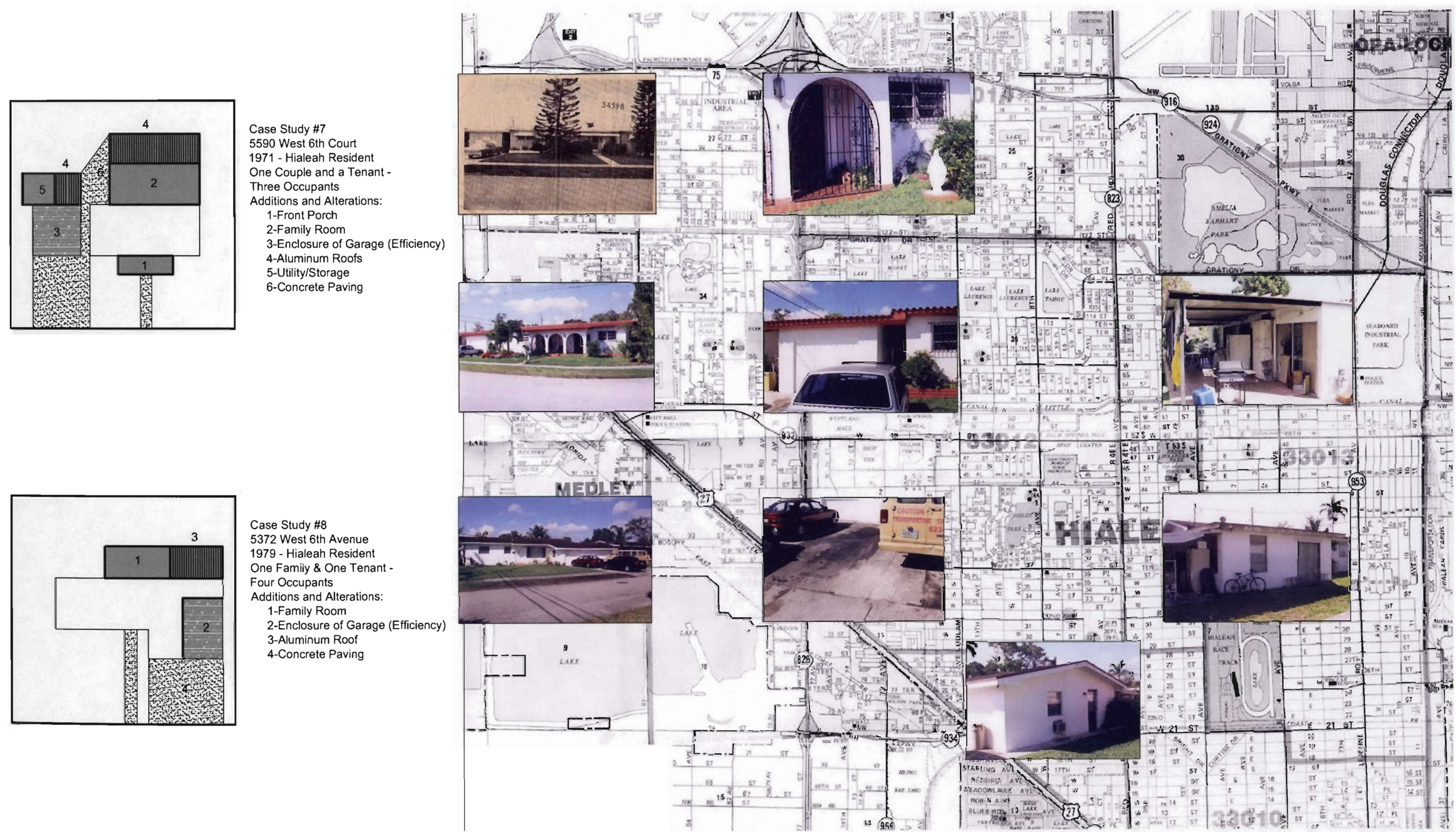


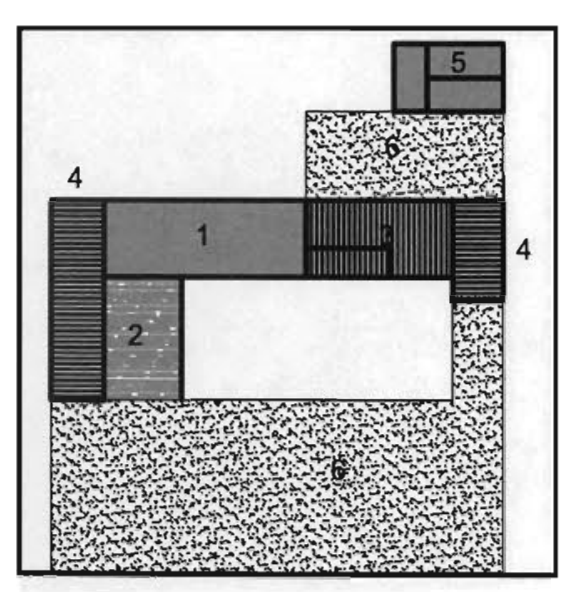

Case Study \#9
1895 West 64 Street
$1980-$ Hialeah Residet

1980 - Hialeah Resident

One Family \& One Tena

Additions and Alterations:

1-Family Room

2-Enclosure of Garage (Efficiency)

3-Laundry \& Extra Kitchen Area

4-Aluminum Roofs

6-Concrete Paving

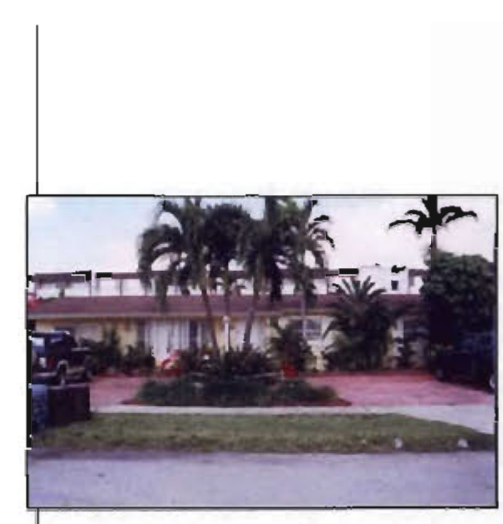

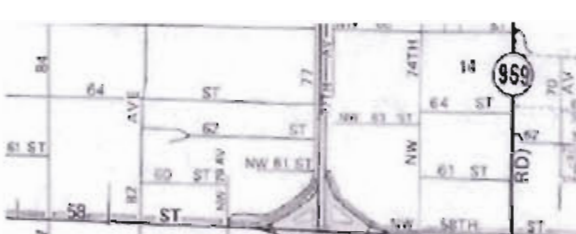

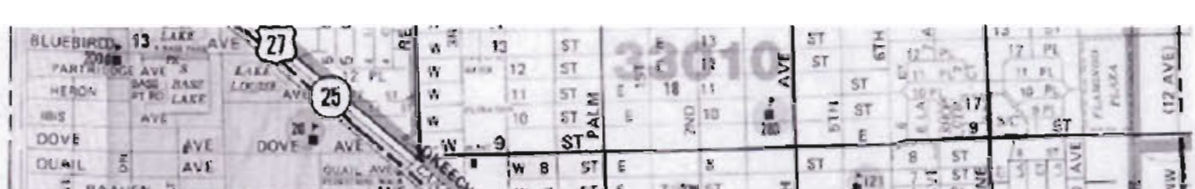

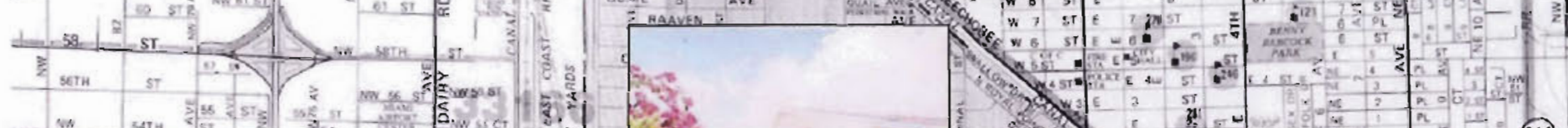

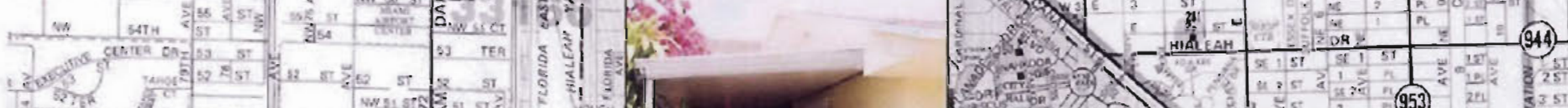
13.

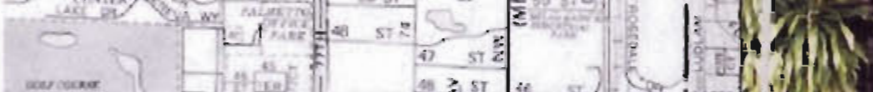
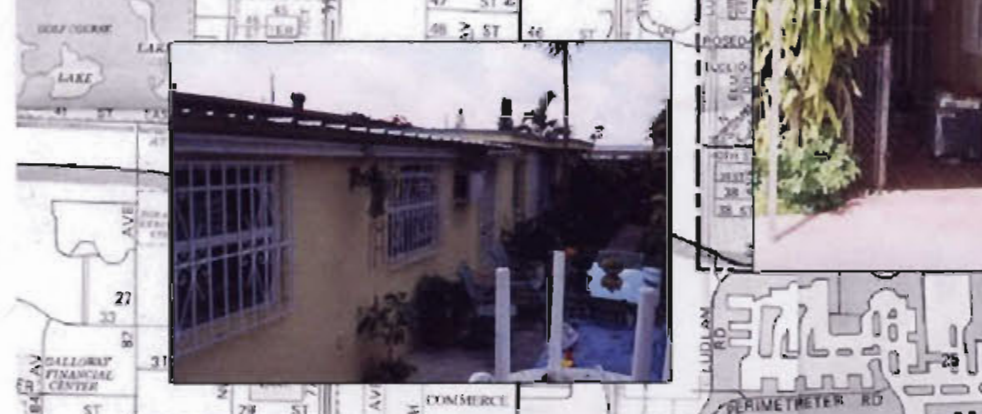

bis.

(5)

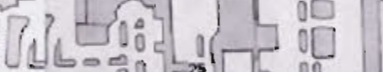

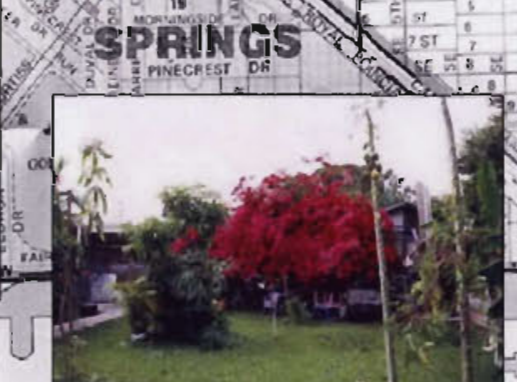

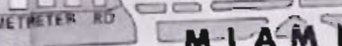
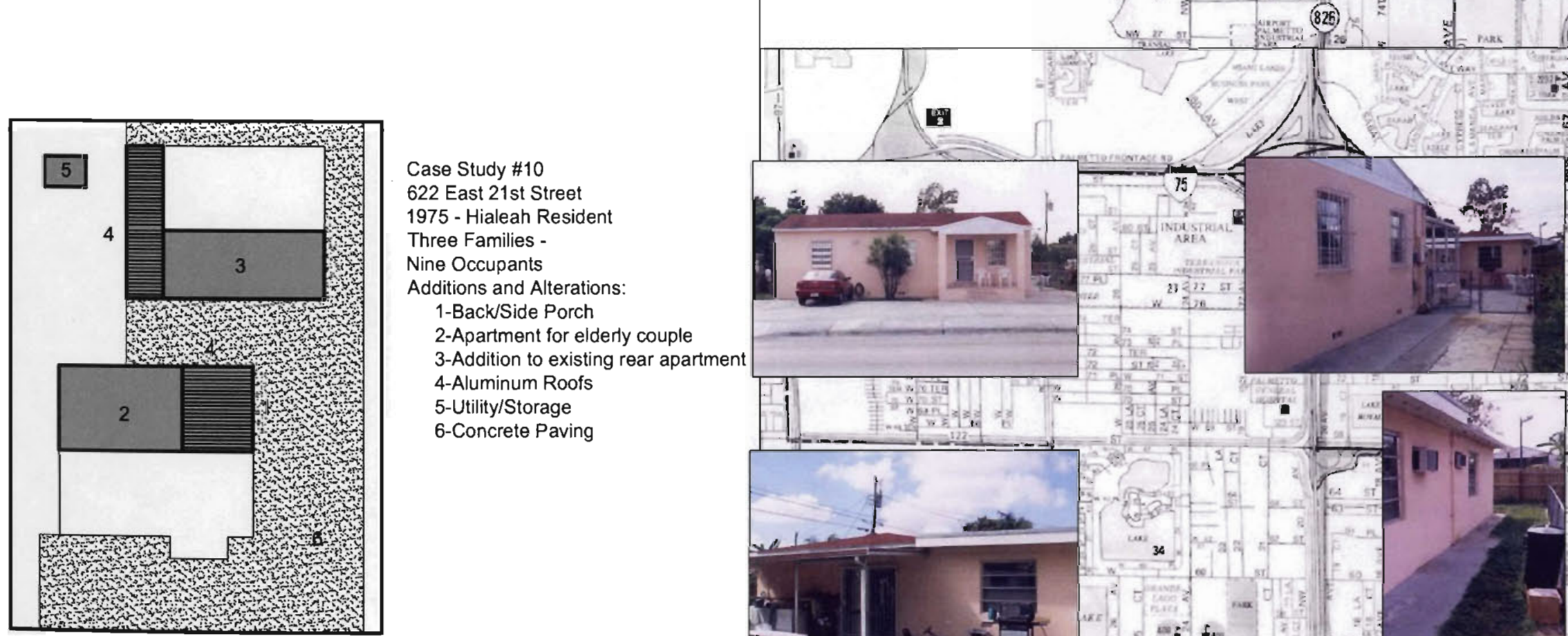

Case Study \#10

622 East 21st Street

Three Families -

Additions and Alterations:

1-Back/Side Porch

2-Apartment for elderly couple

3-Addition to existing rear apartme

4-Aluminum Roofs

6-Concrete Paving
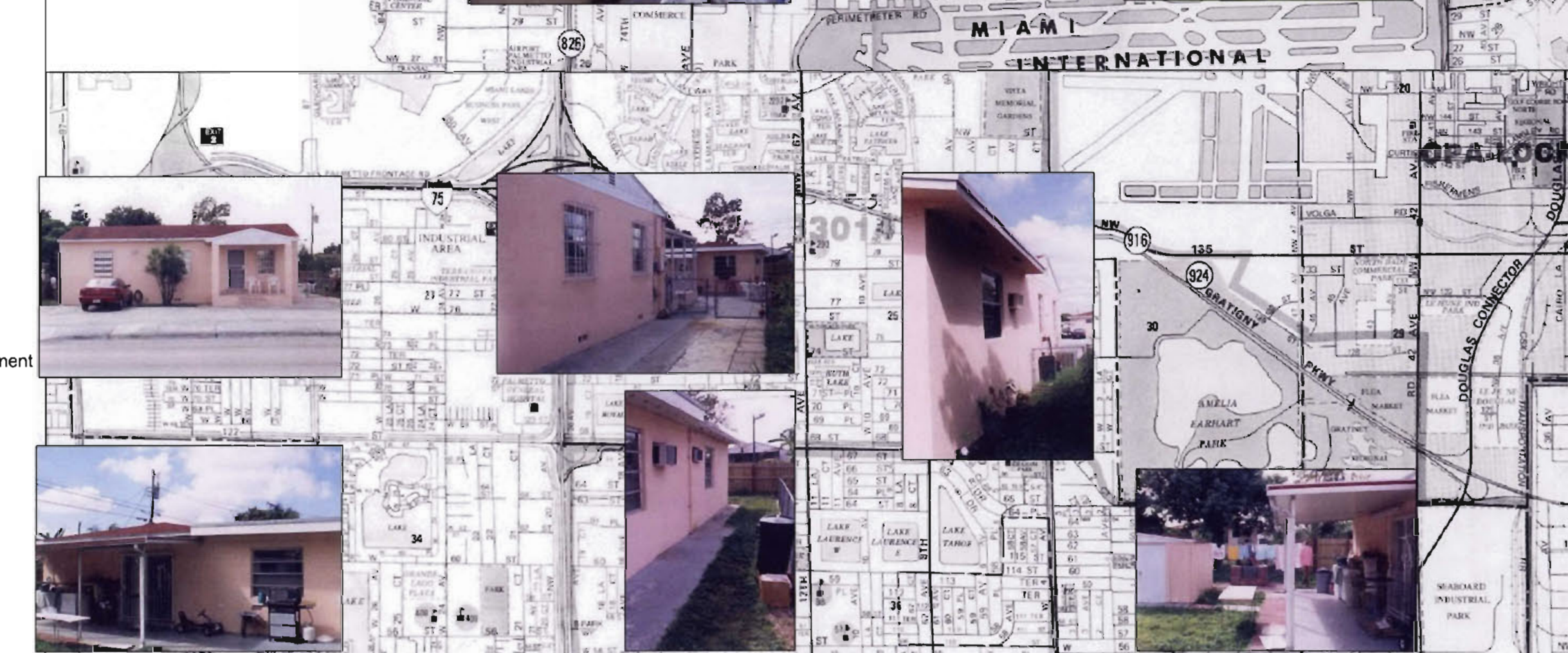

E.t.
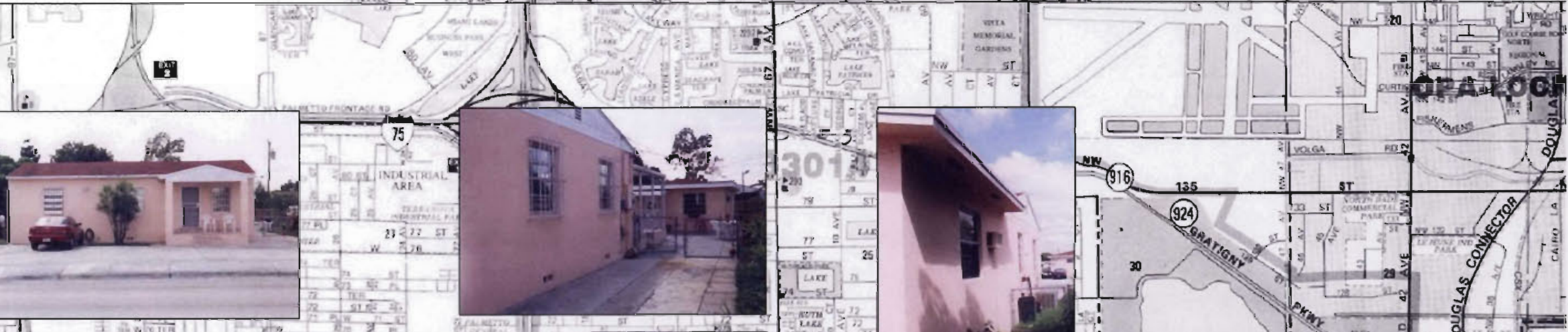

$\mathrm{H}^{2} \rightarrow \mathrm{L}$
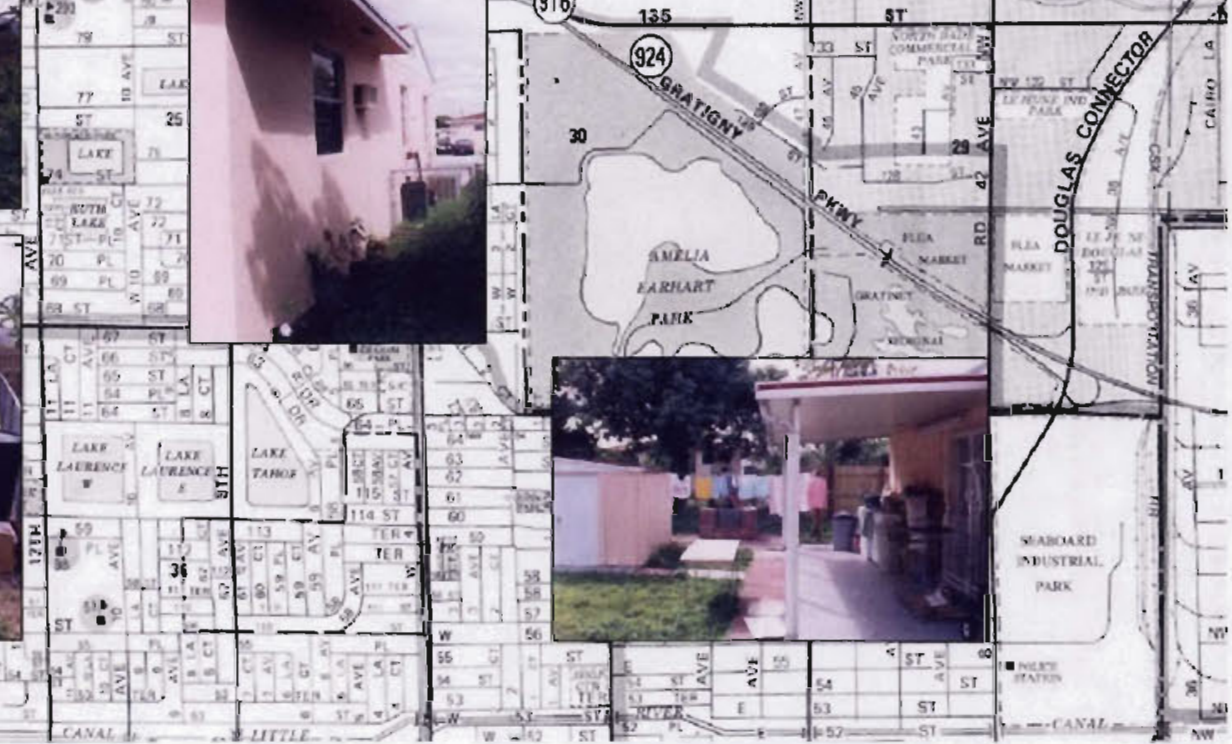


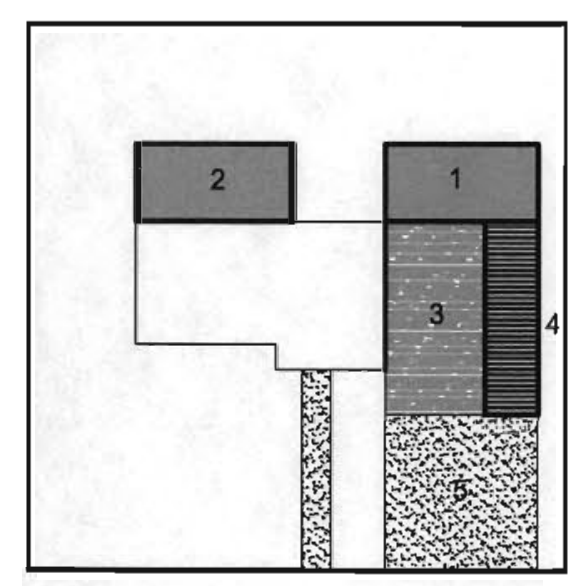

Case Study \#11

5390 West 6th Avenue

One Family \& One Tenant -

Four Occupants

Ad-Family Room
Aditions and Altration:

2-Extra Room

3-Enclosure of Garage (Efficiency)

5-Concrete Paving

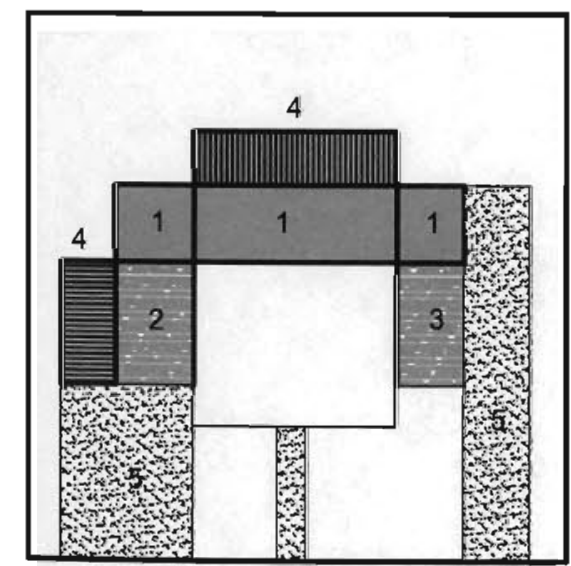

Case Study \#12

1875 West 64 Street
1968 - Hialeah Residen

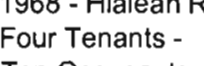

Additions and Alterations:

1-Extra Rooms

2-Enclosure of Garage (Efficiency)

3-Making room into efficiency

5-Concrete Paving

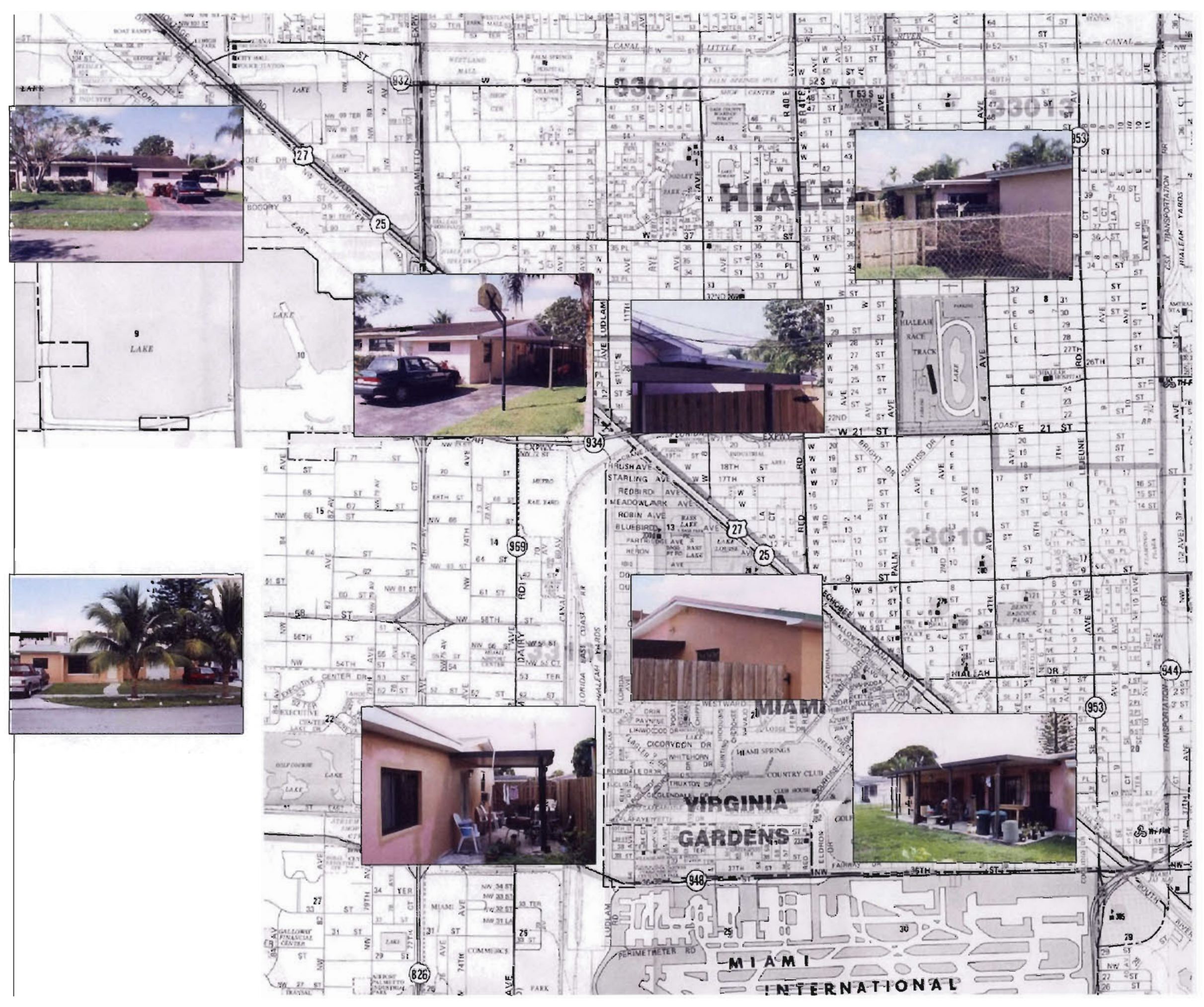




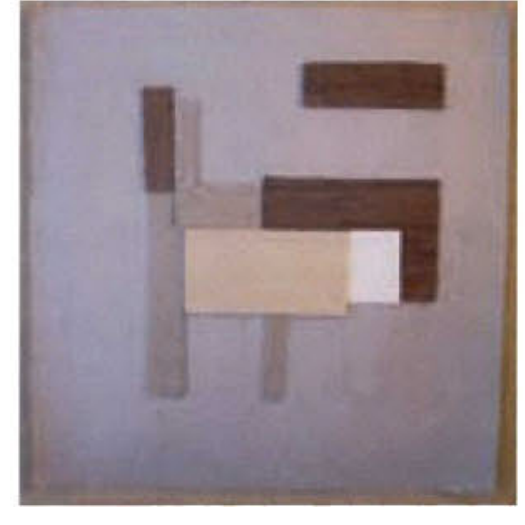

\#3

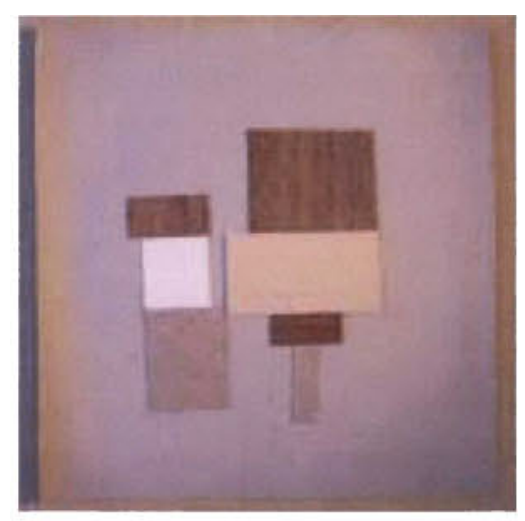

\#7

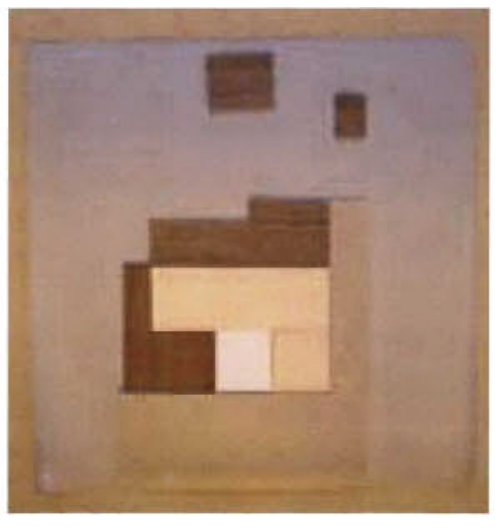

\#4

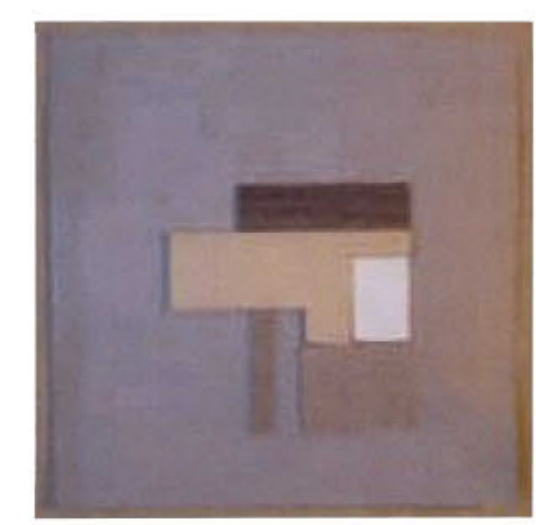

\#8

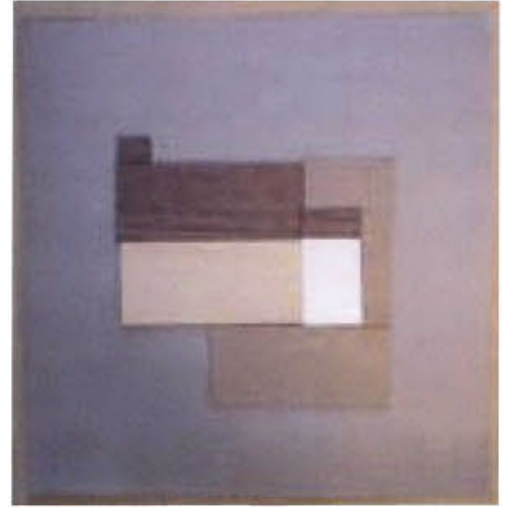

\#5

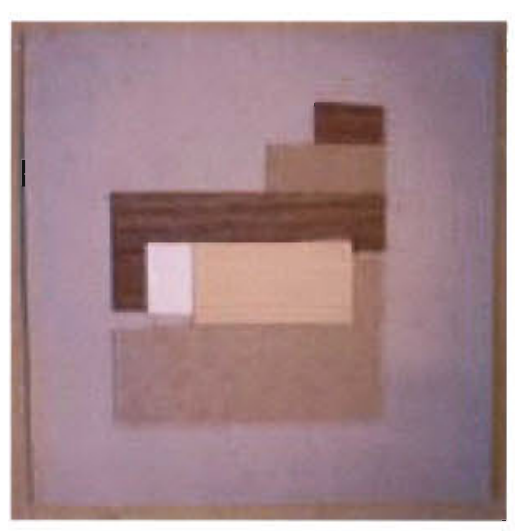

\#9

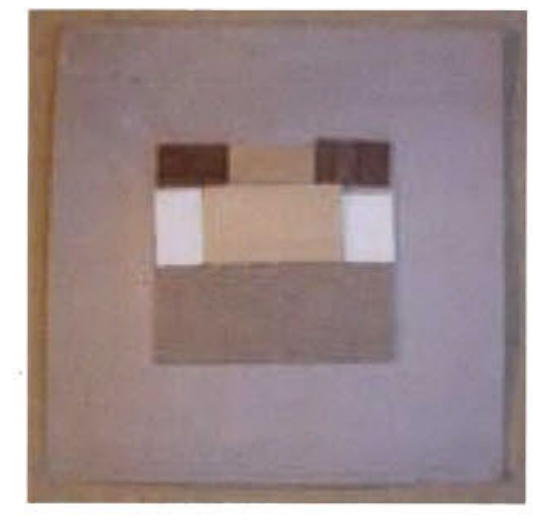

\#6

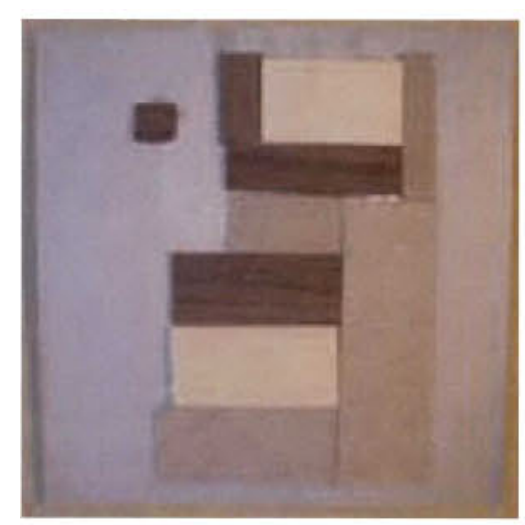

\#10 

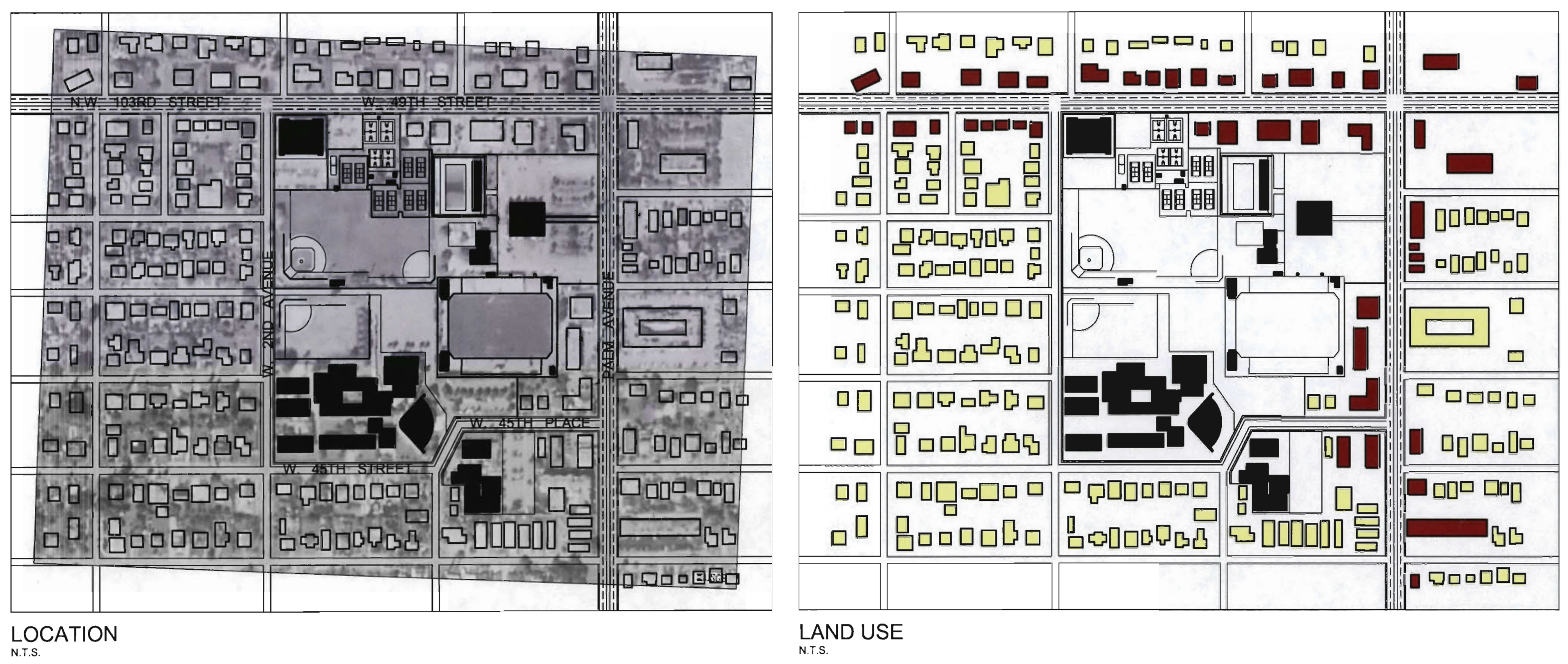

LAND USE 


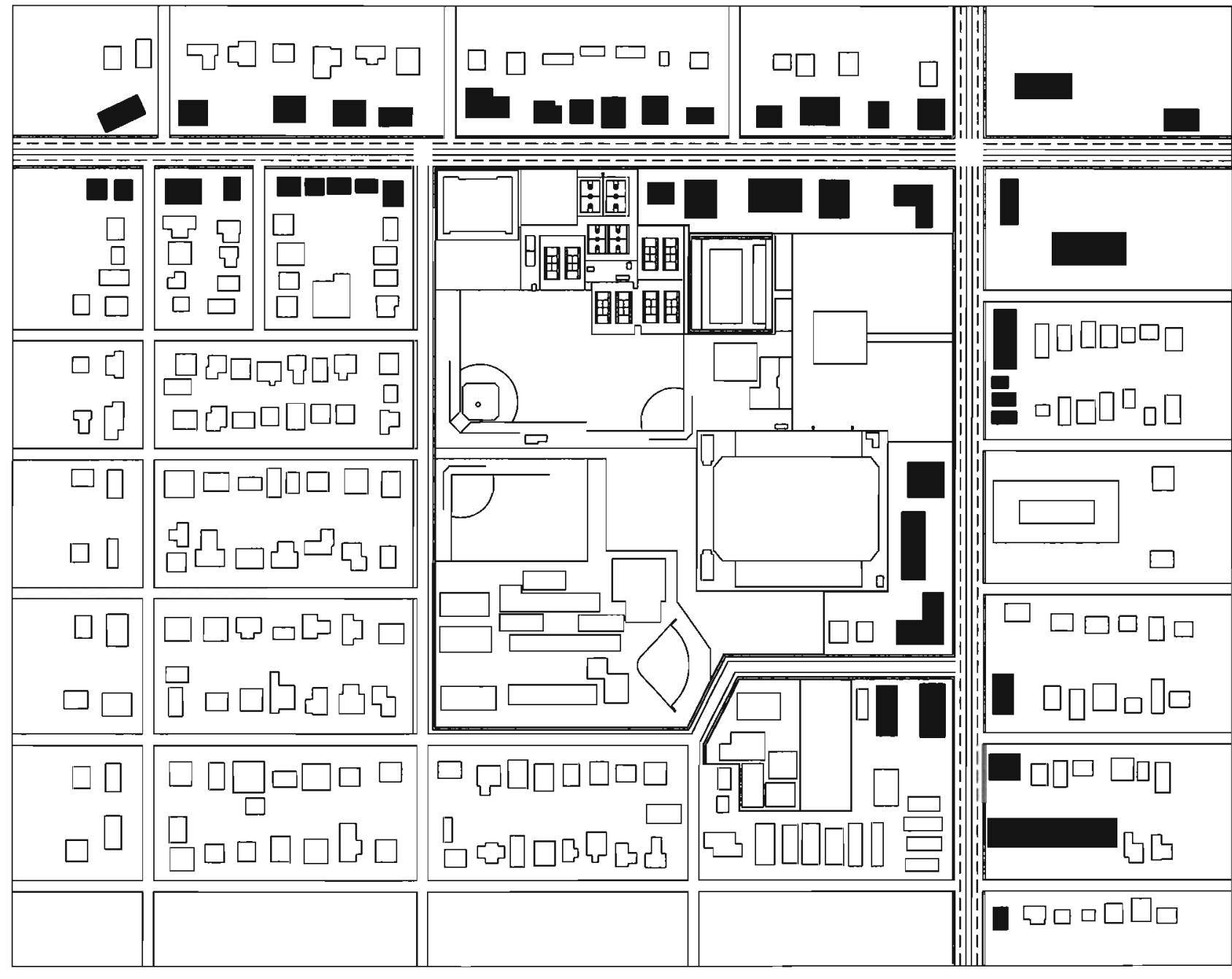

COMMERCIAL

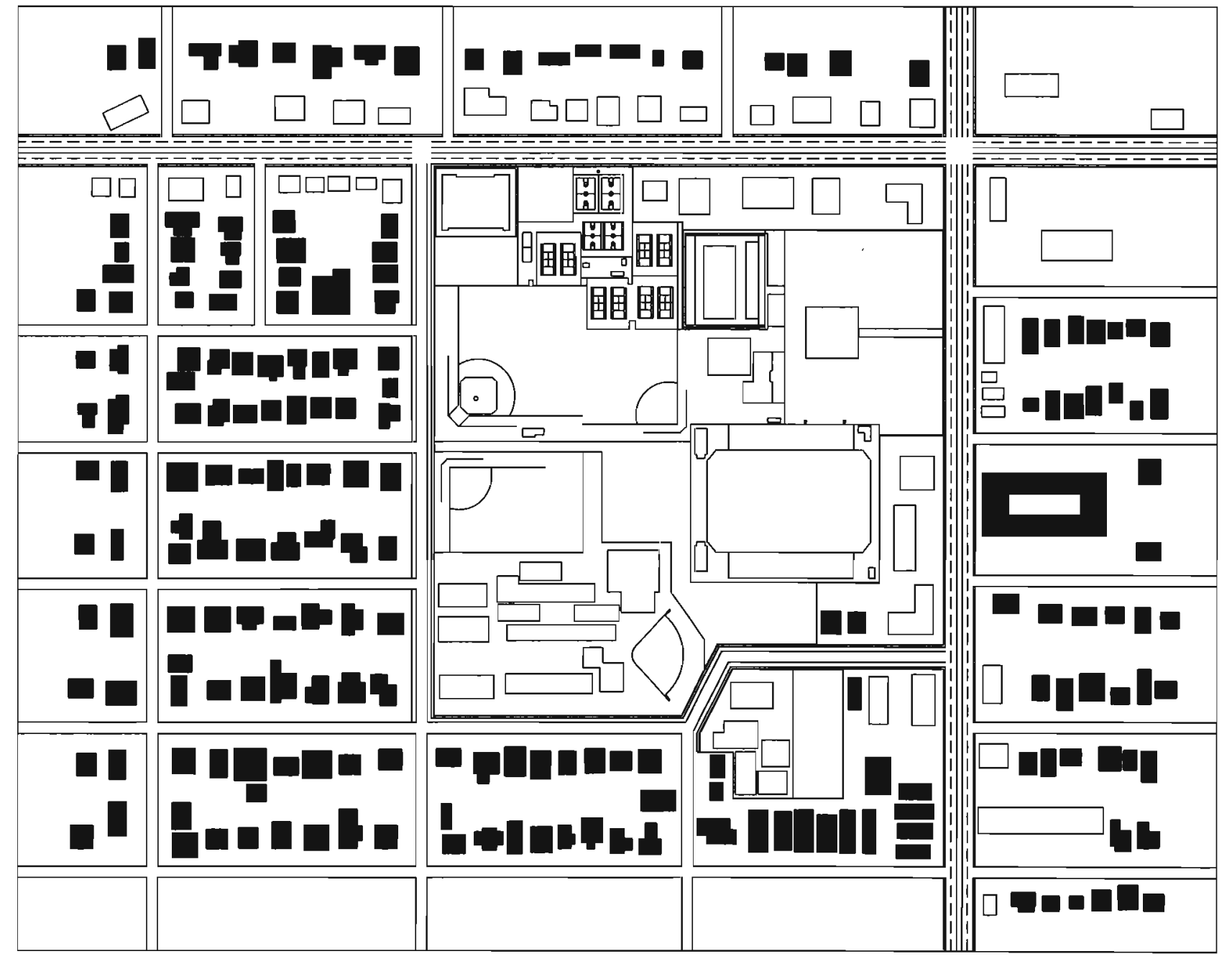

RESIDENTIAL 


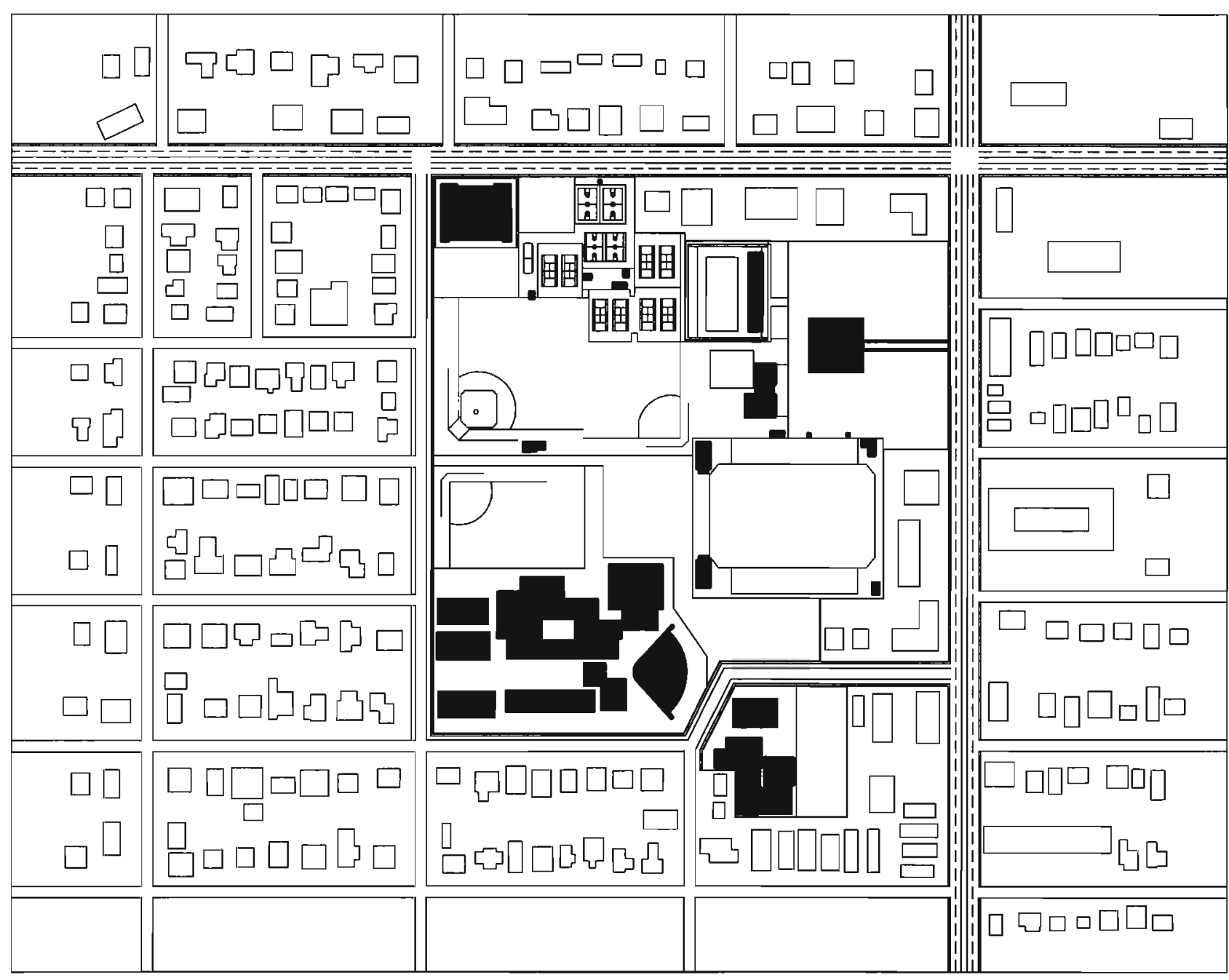

INSTITUTIONAL

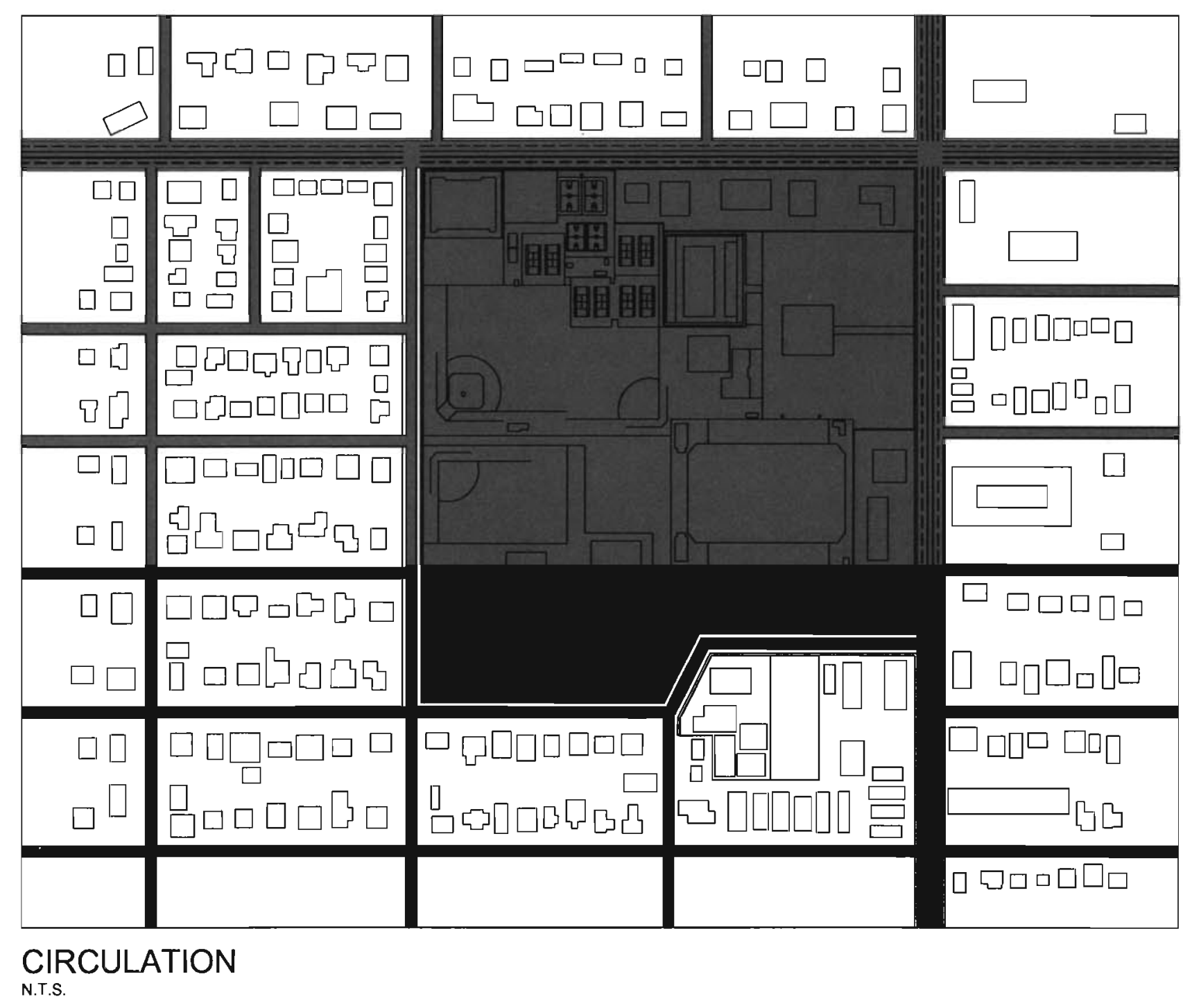




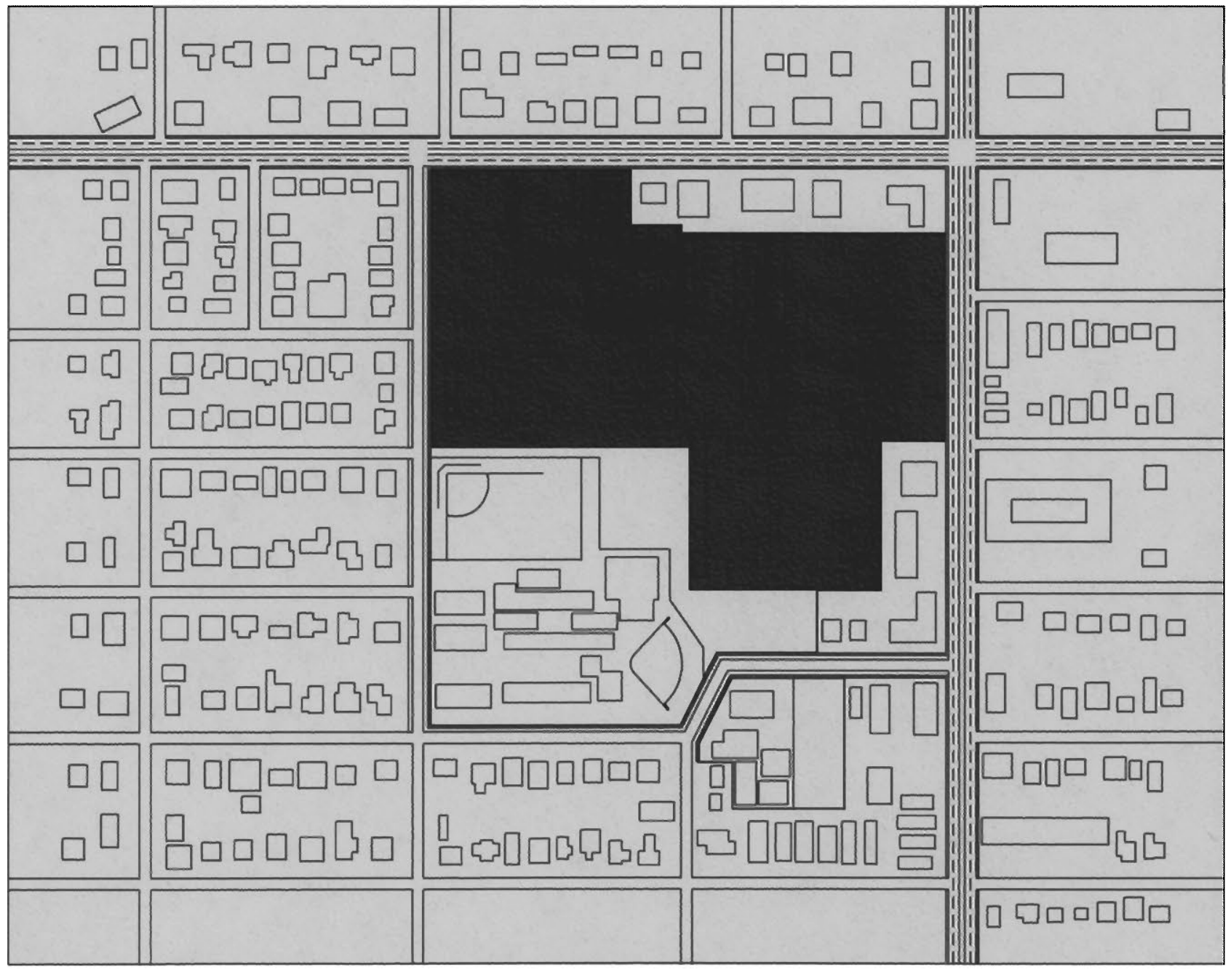

PUBLIC

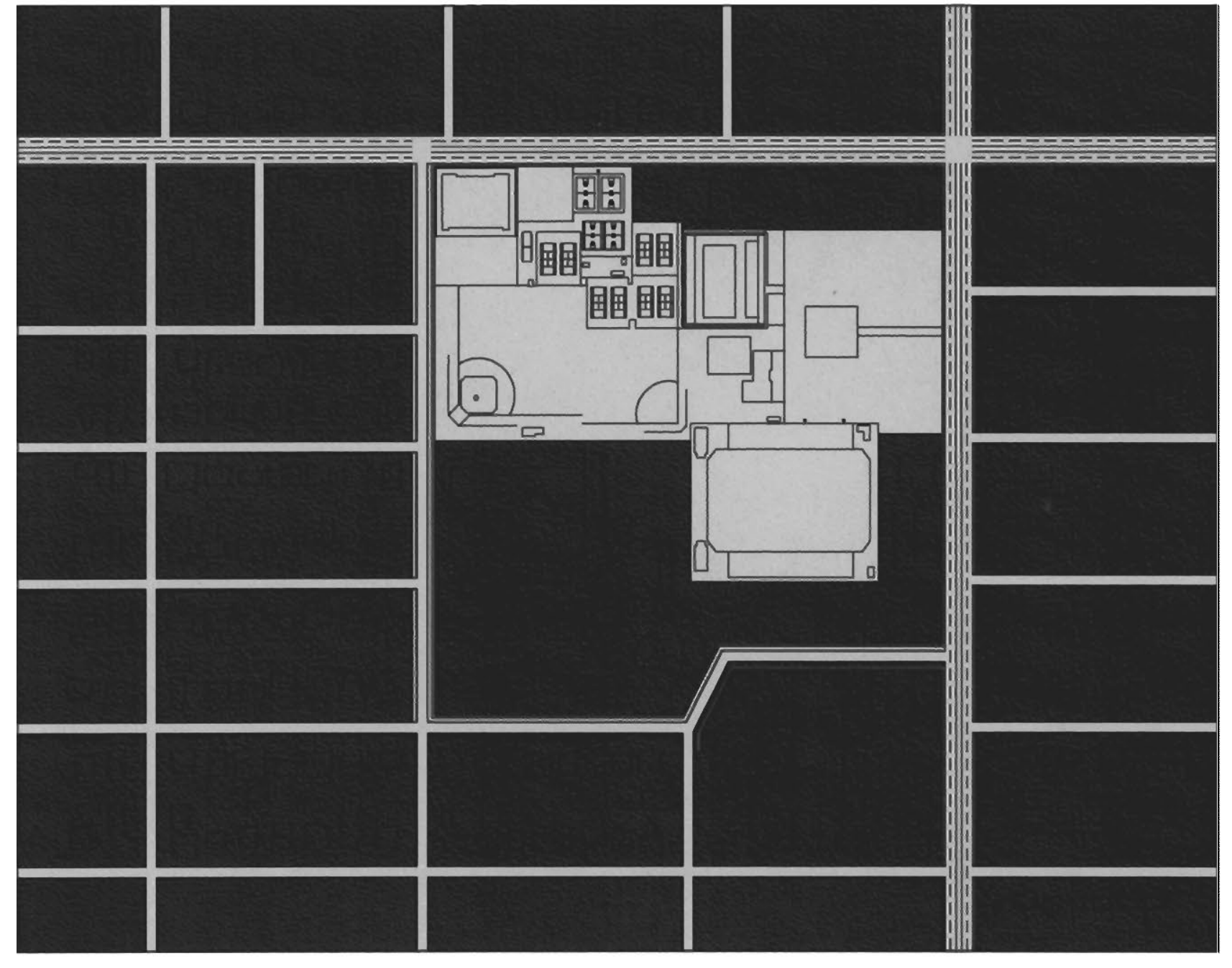

PRIVATE 


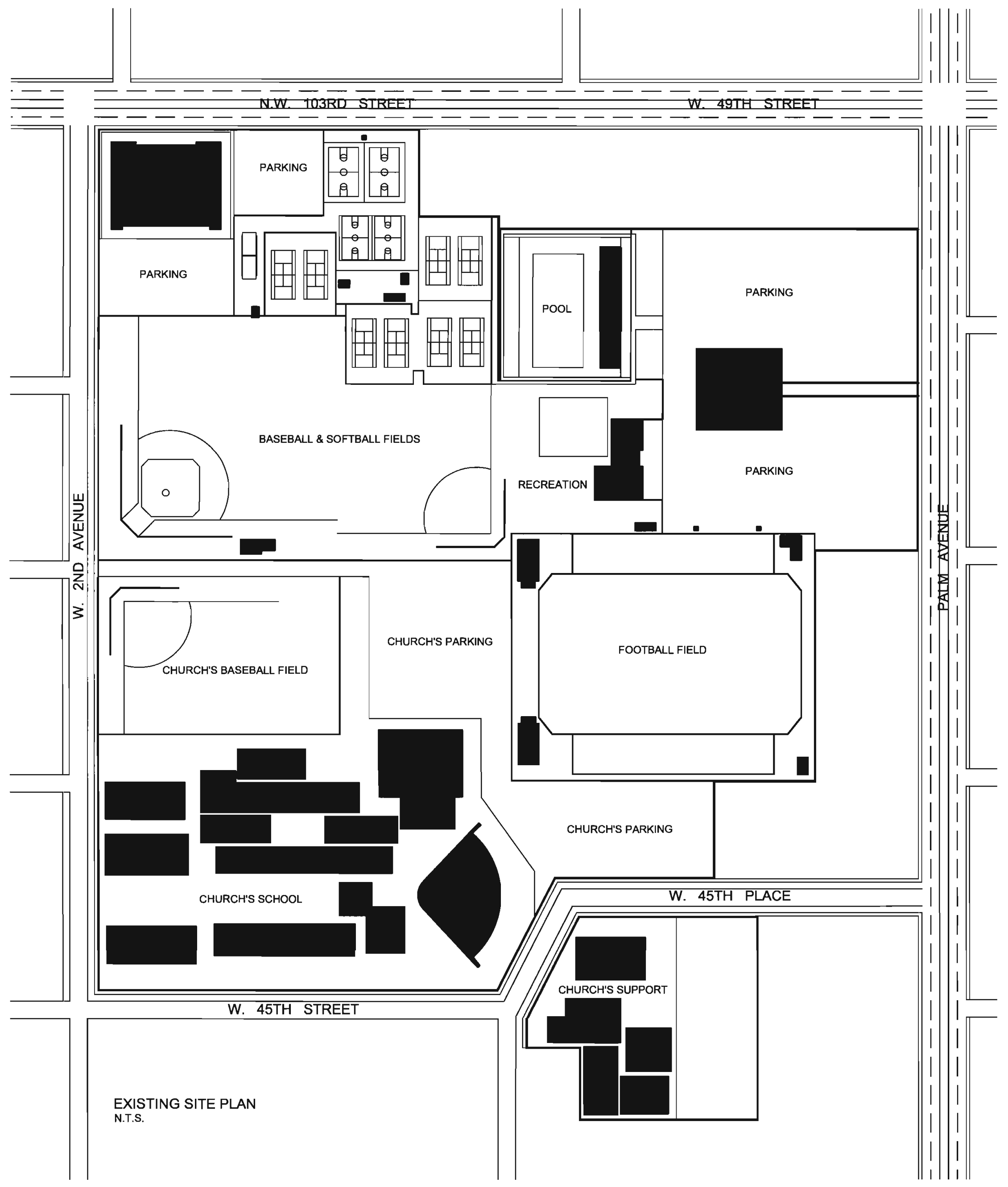




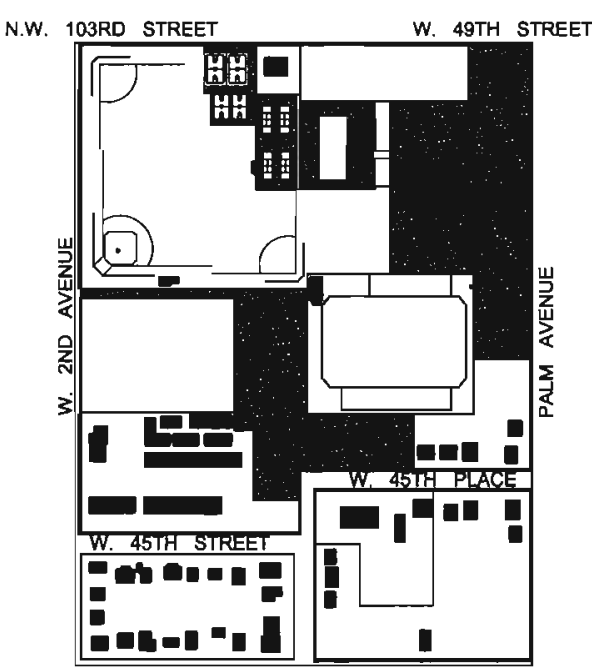

$\underset{\text { STS }}{\text { STUY AREA }}$

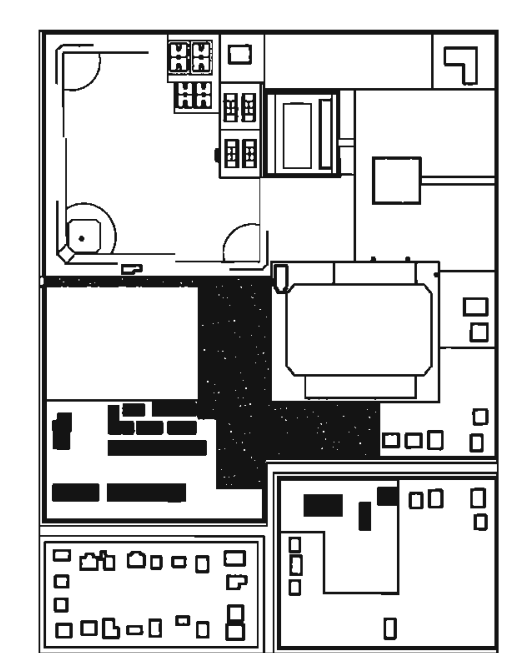

CHURCHISCHOOL

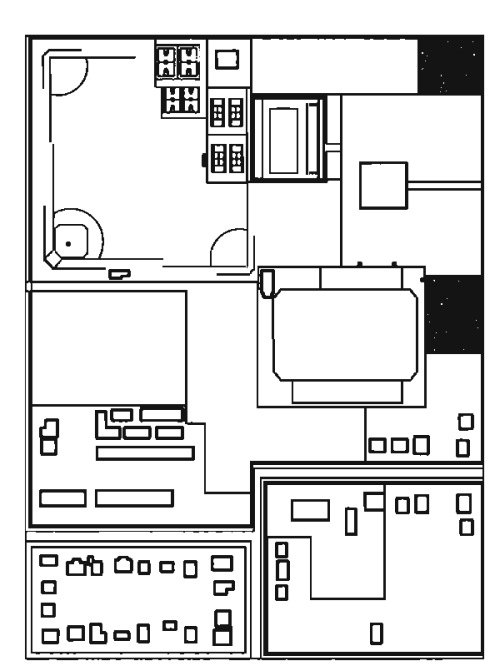

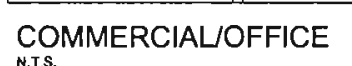

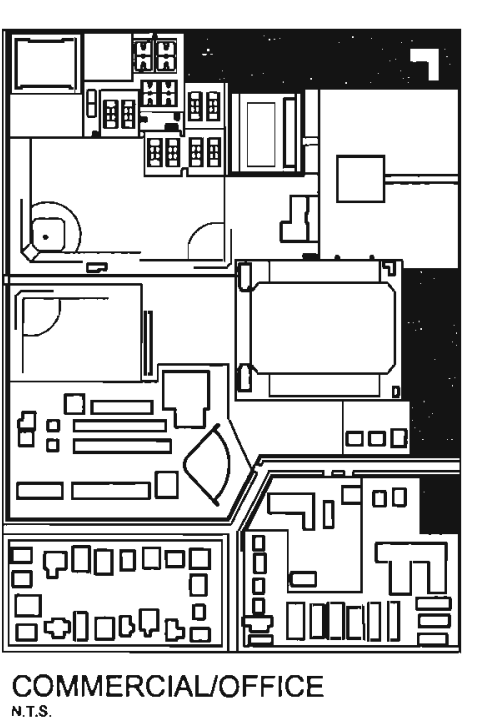

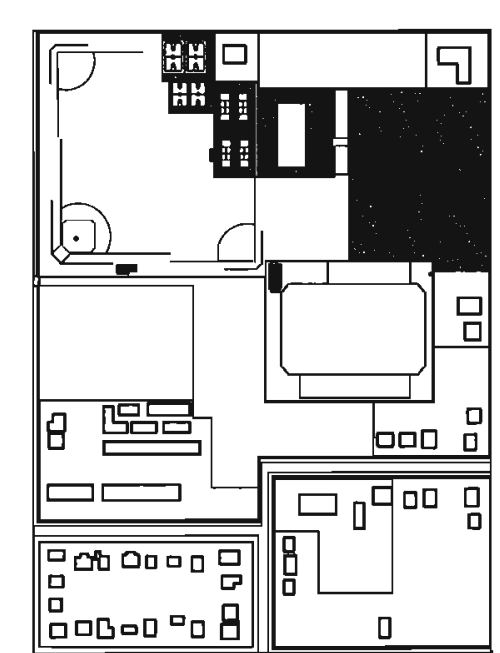

PARKRECREATION

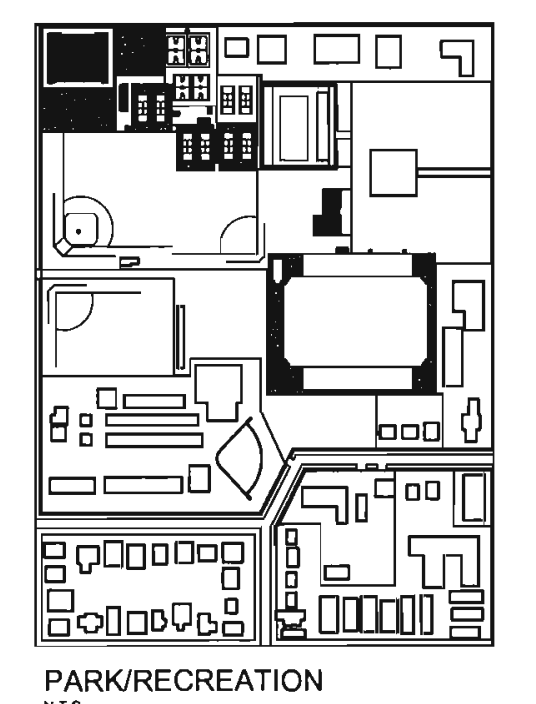

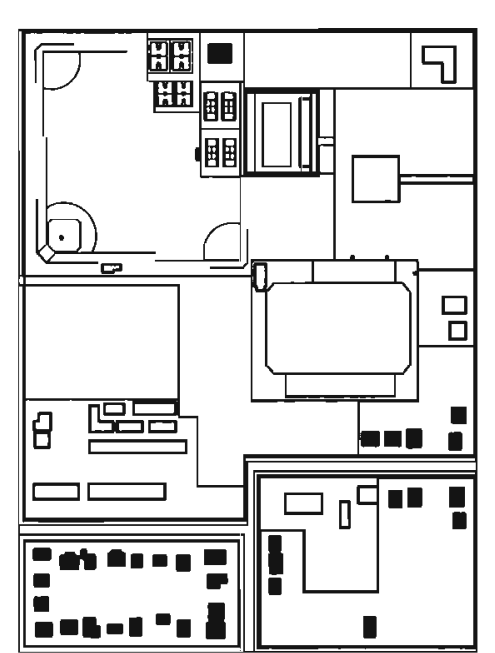

$\underset{r=s}{R E S I D E N T I A L}$

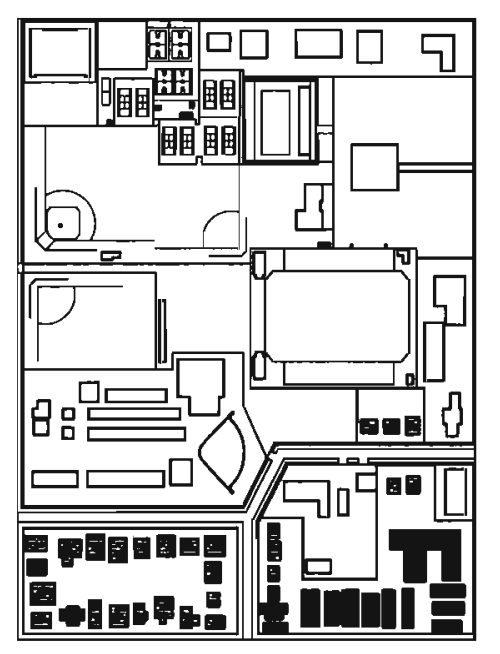

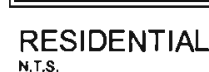

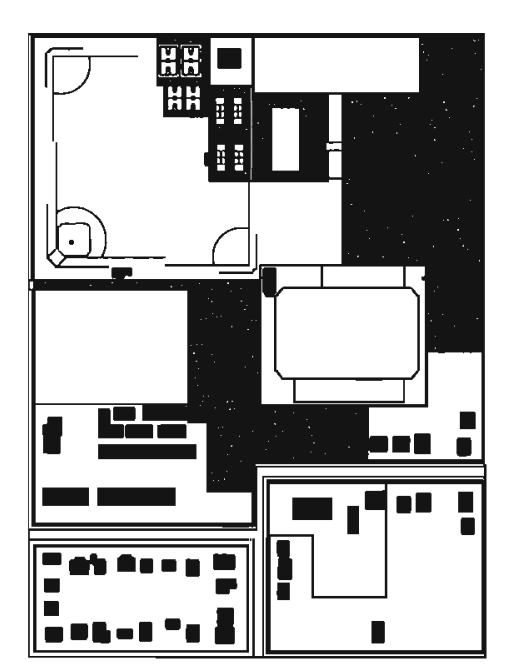

$\underset{1.52}{1962}$

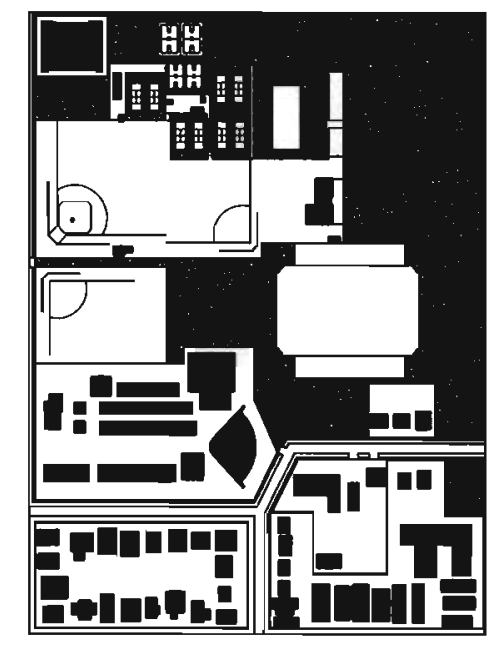

1980 


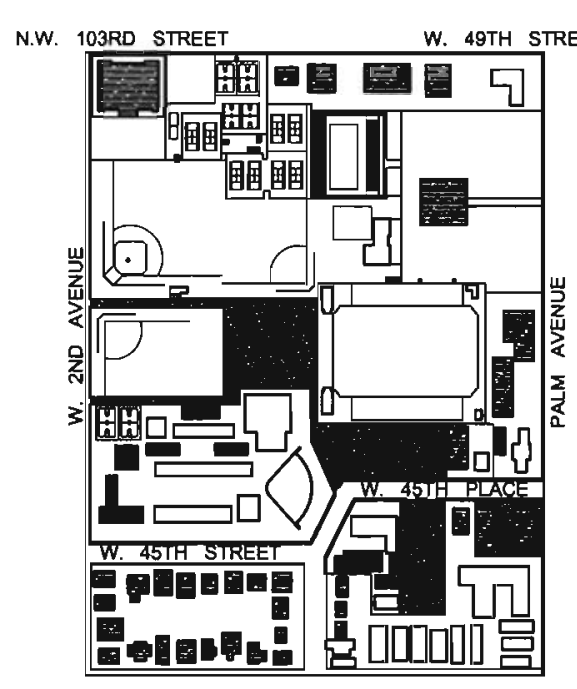

STTUDY AREA
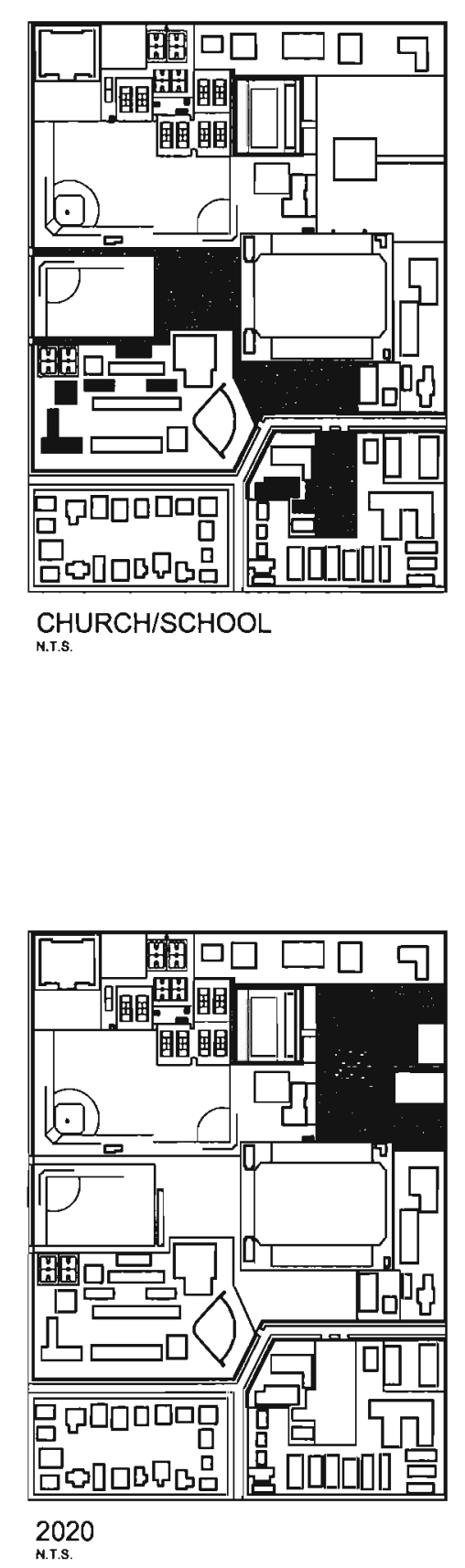
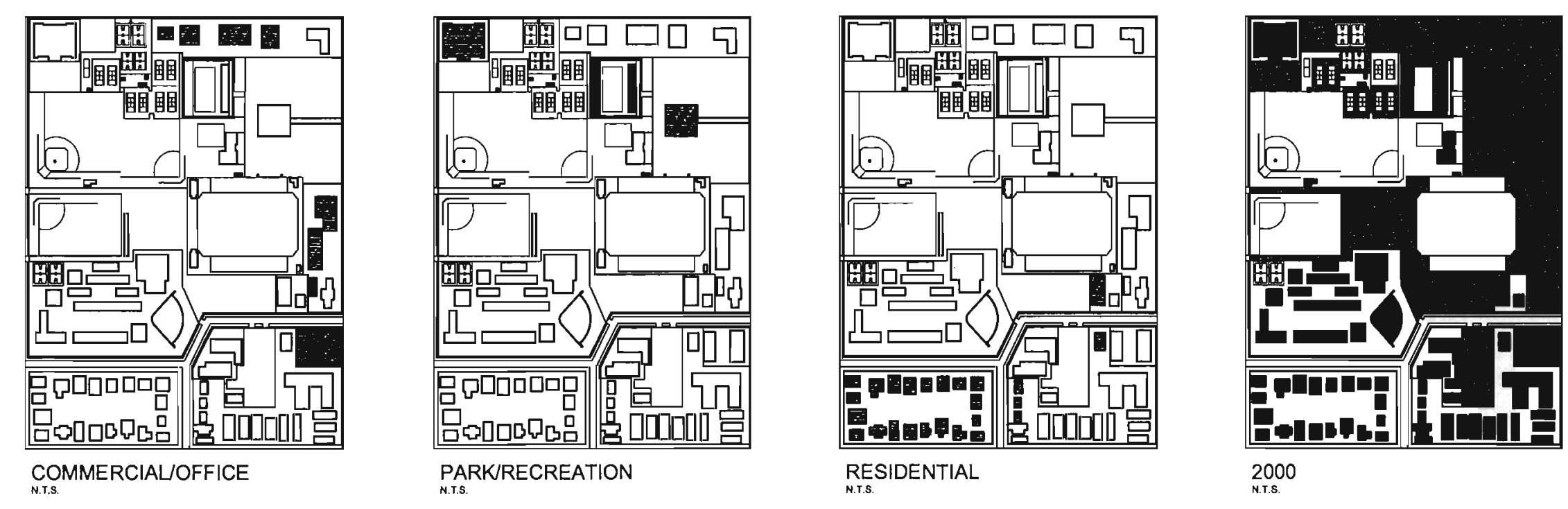

2000
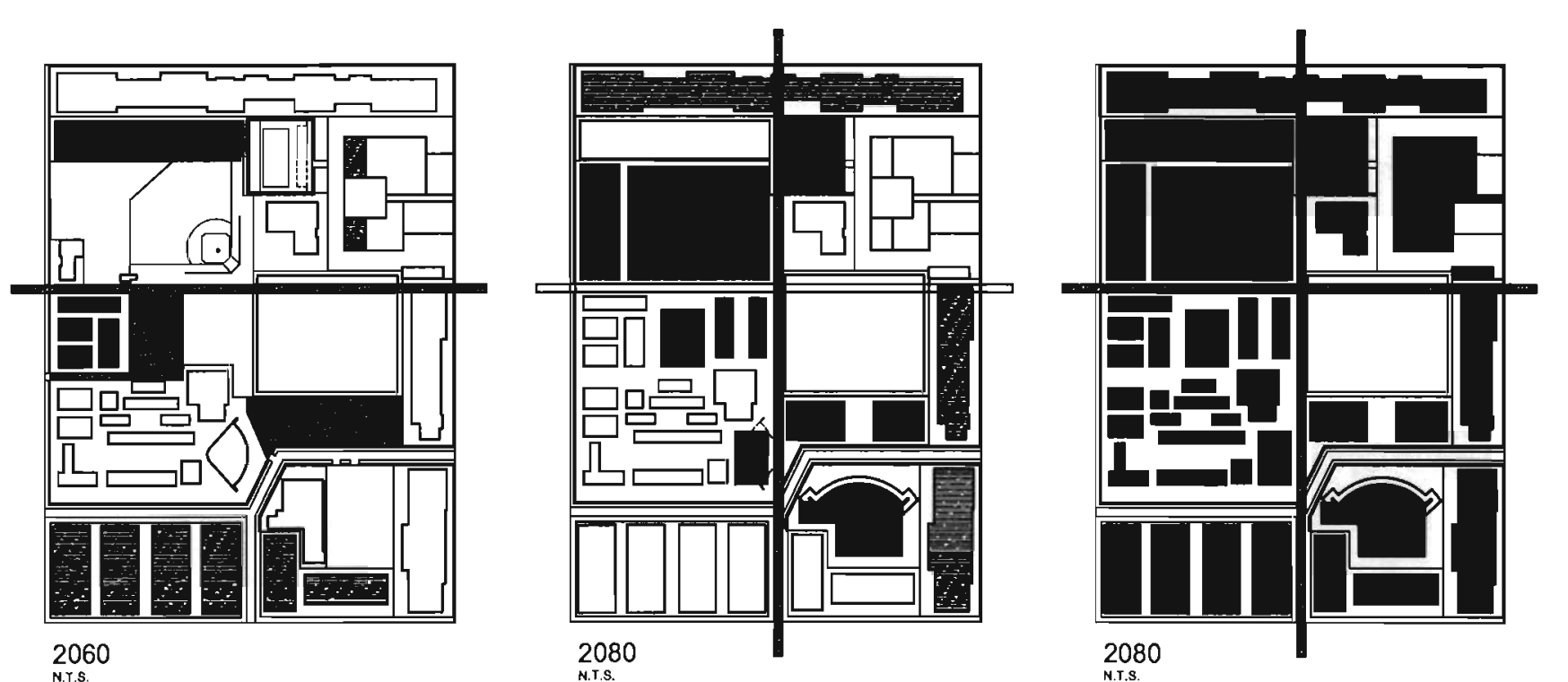

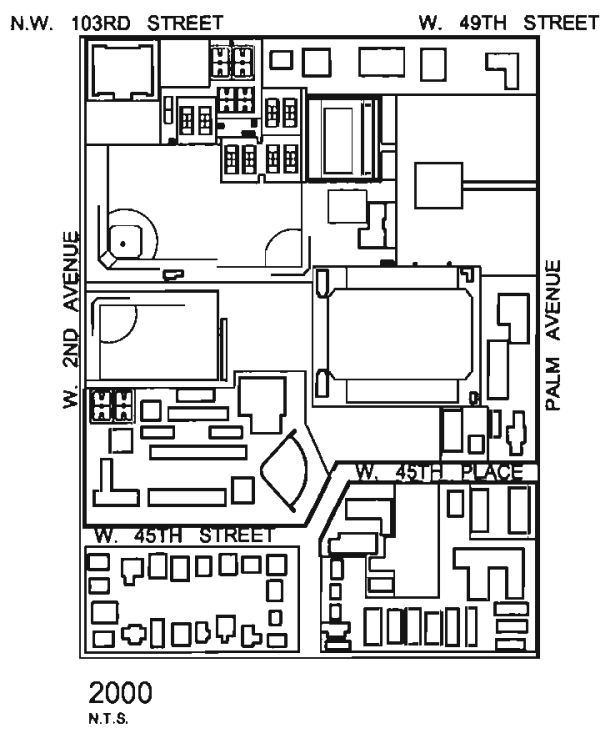



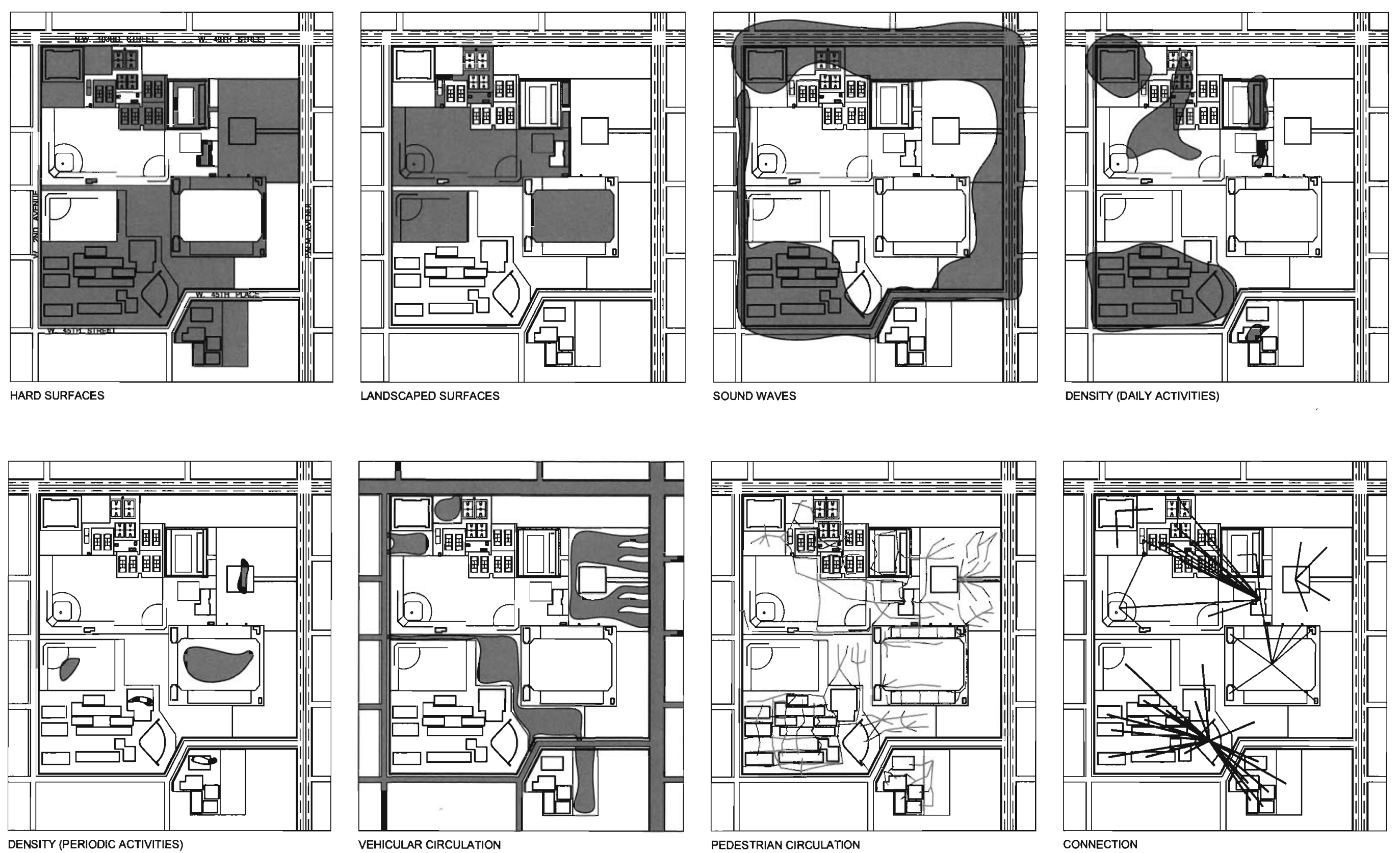

PROPOSED PROGRAM

A-MUSEUM

B-CAFE

-OPEN GALLERY
-MURALS

-SCULPTURES

D-OUTDOOR THEATRE
E-OPEN PATIOS F-INTERIOR PATIOS G-BAR-B-Q AREAS H-AGRICULTURAL \& GARDEN AREA
I-WATER ELEMENTS

\section{J-PUBLIC TRANSPORTATION DROP-OFF AREA} K-PARKING AREA
CONCEPTS

INTERACTIVE

FLUIDITY

DIVERSITY

MIRROR

REFLECTION
MOVEMENT INFORMAL FRAGMENTED SCATTERED
SPONTANUITY AMORPHOUS
UNIFORMITY FLEXIBILITY ATTACHED DETACHED ENCLOSED
CONNECTION

LINKING

BRIDGING

N 


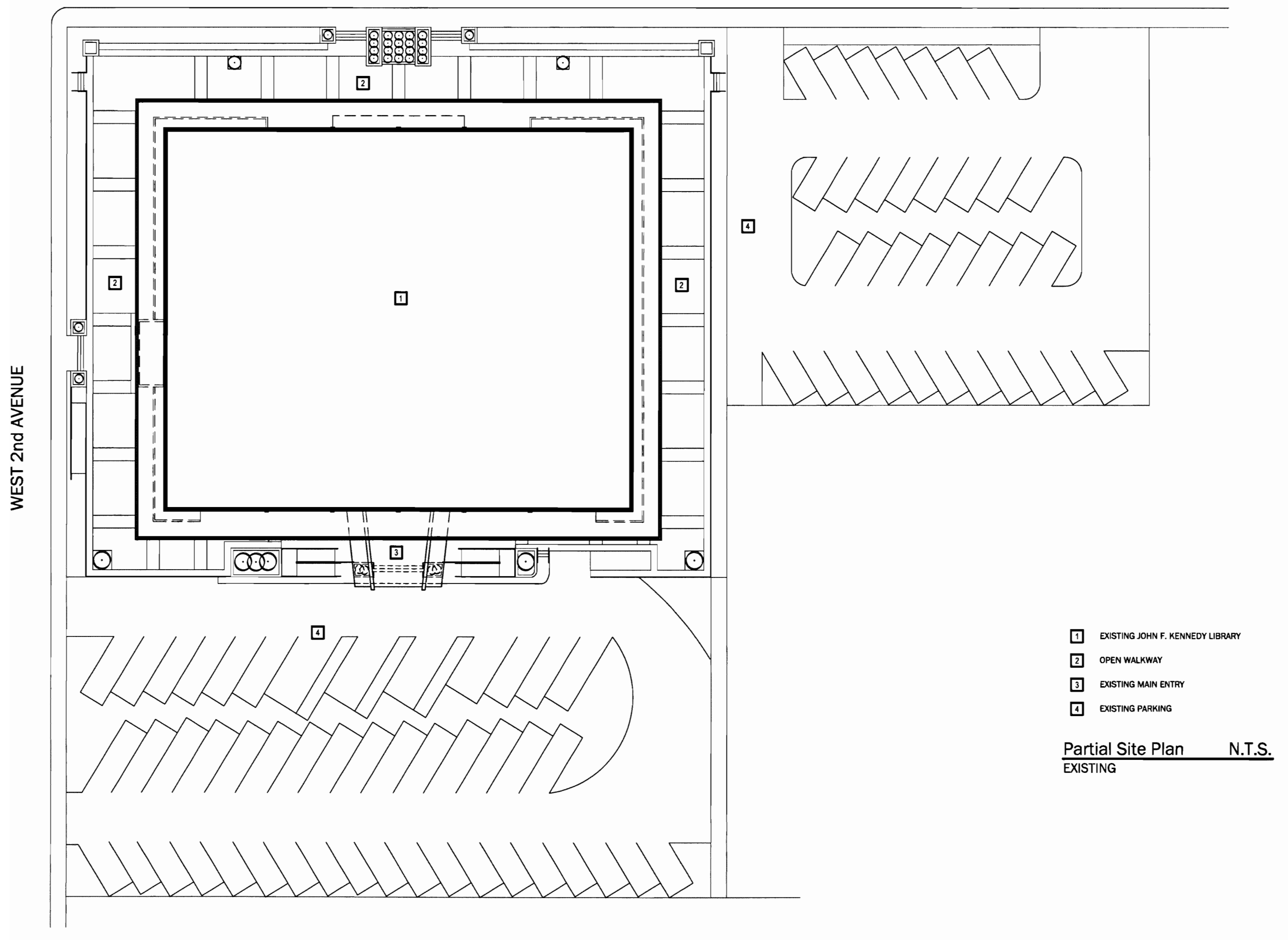




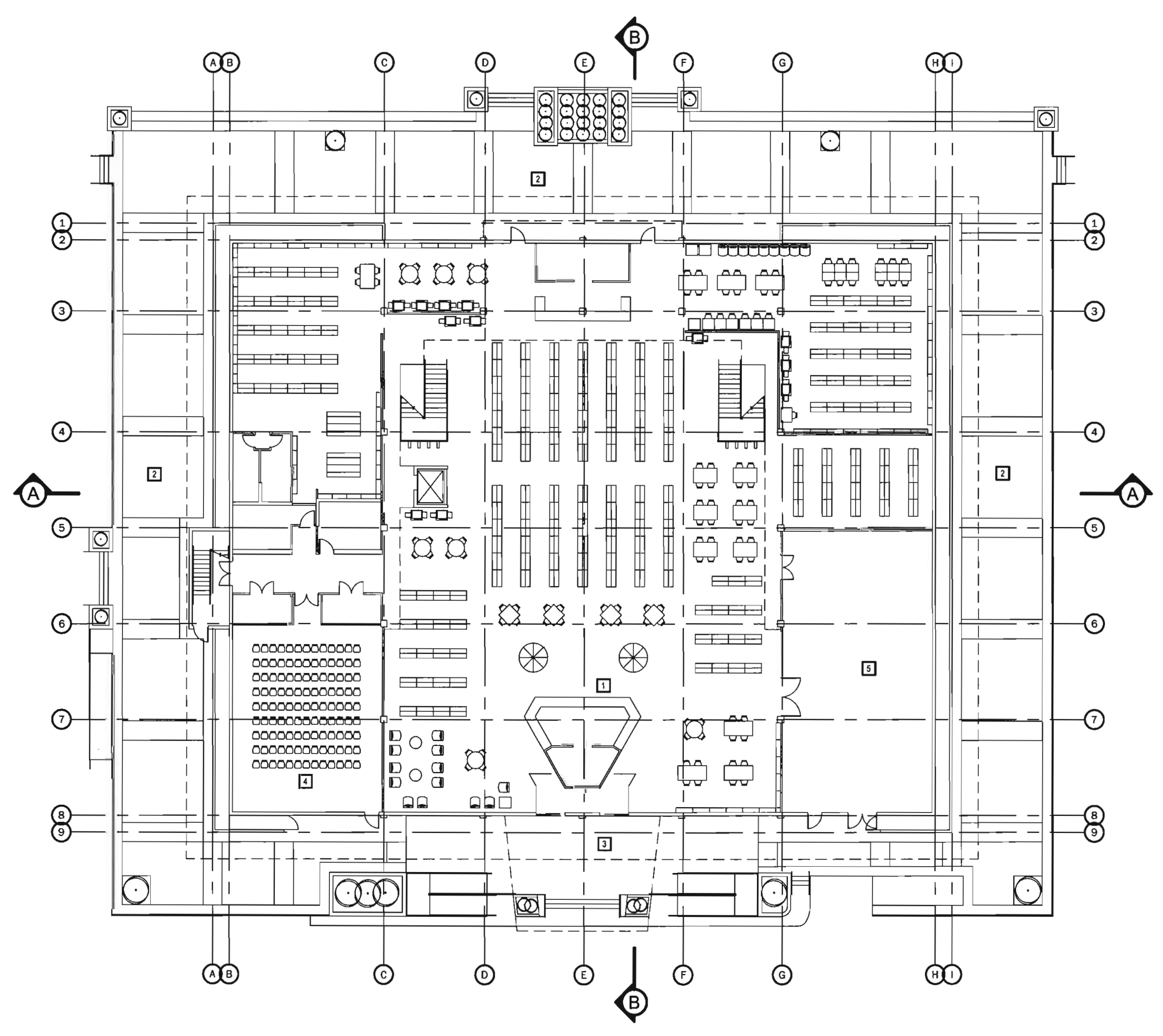
1 EXSTING JOHN F. KENNEDY LBRAPY
2. OPEN WALKWAY
3 ExISTNG MaAN ENTRY
4 ENISTNG AUDTORIUM
5 ExSTING OFFICES
First Floor Plan
N.T.S.
EXISTING




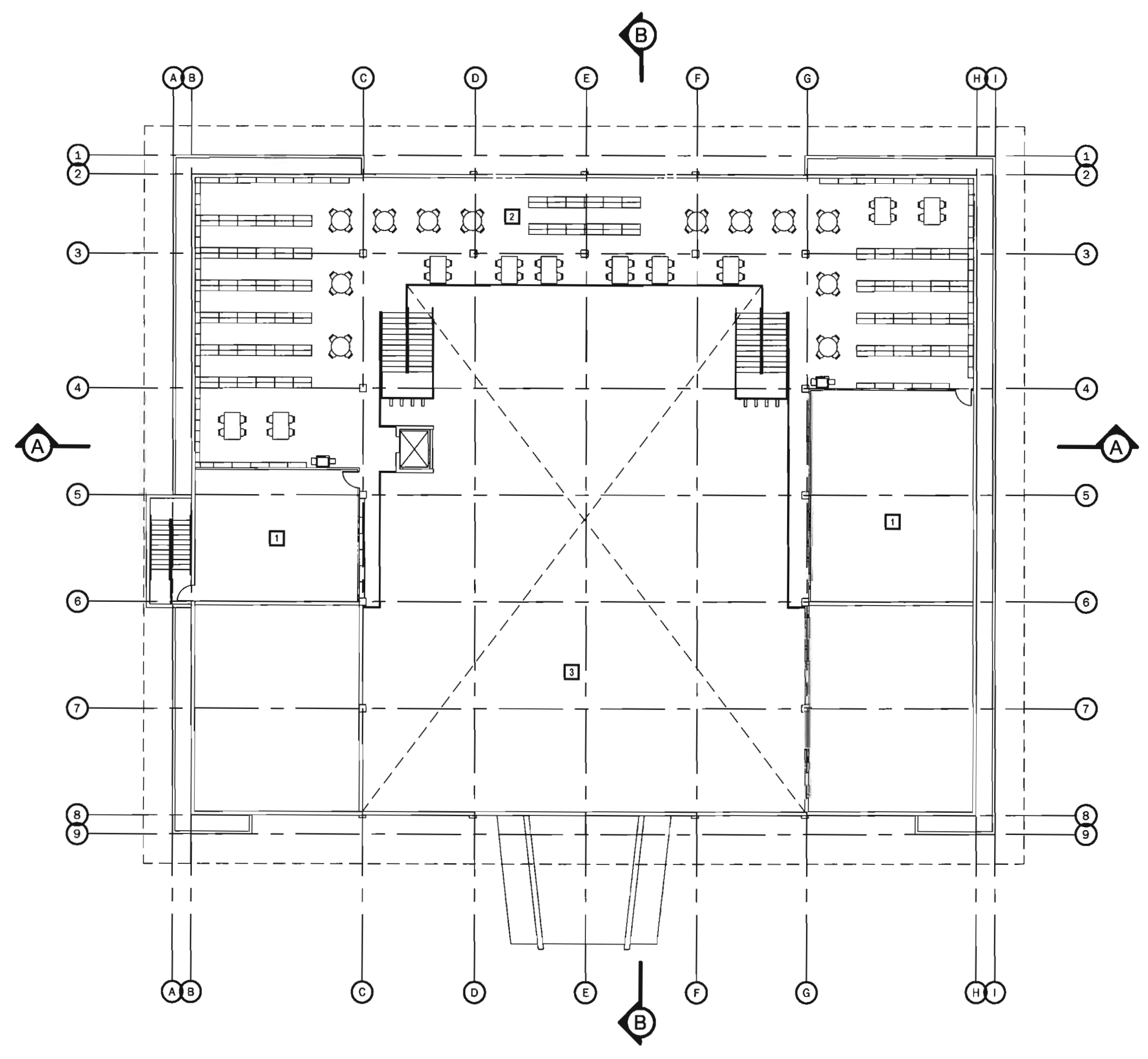

11 EXSTING OFFICSS
1] EXISTING SECONO FLOOR

(3) OPEN To gelow

Second Floor Plan 


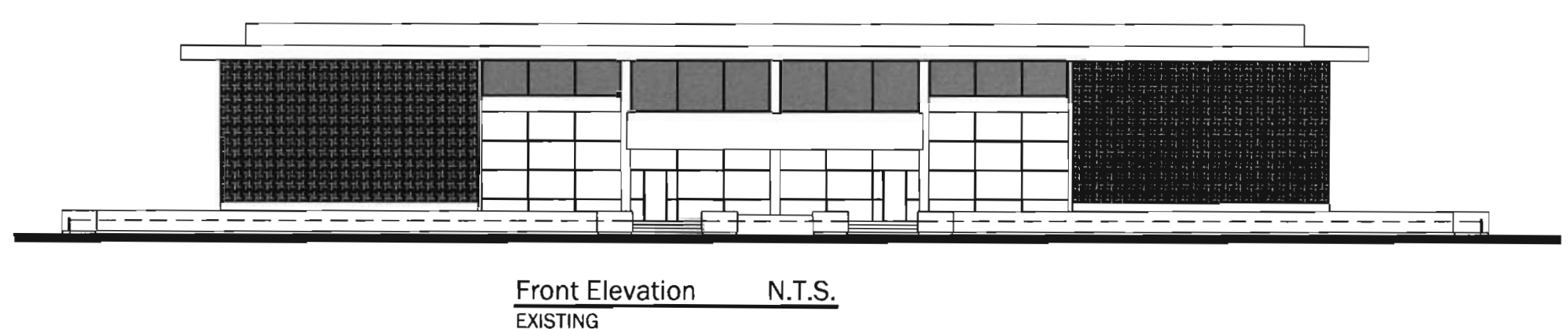

$\frac{\text { Front Elevation }}{\text { EXISTING }}$

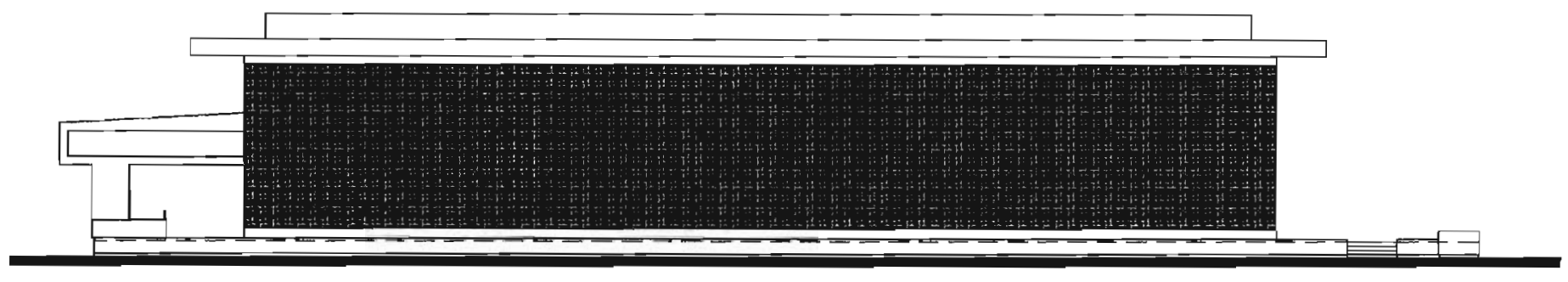

Left Side Elevation N.T.S.

EXISTING
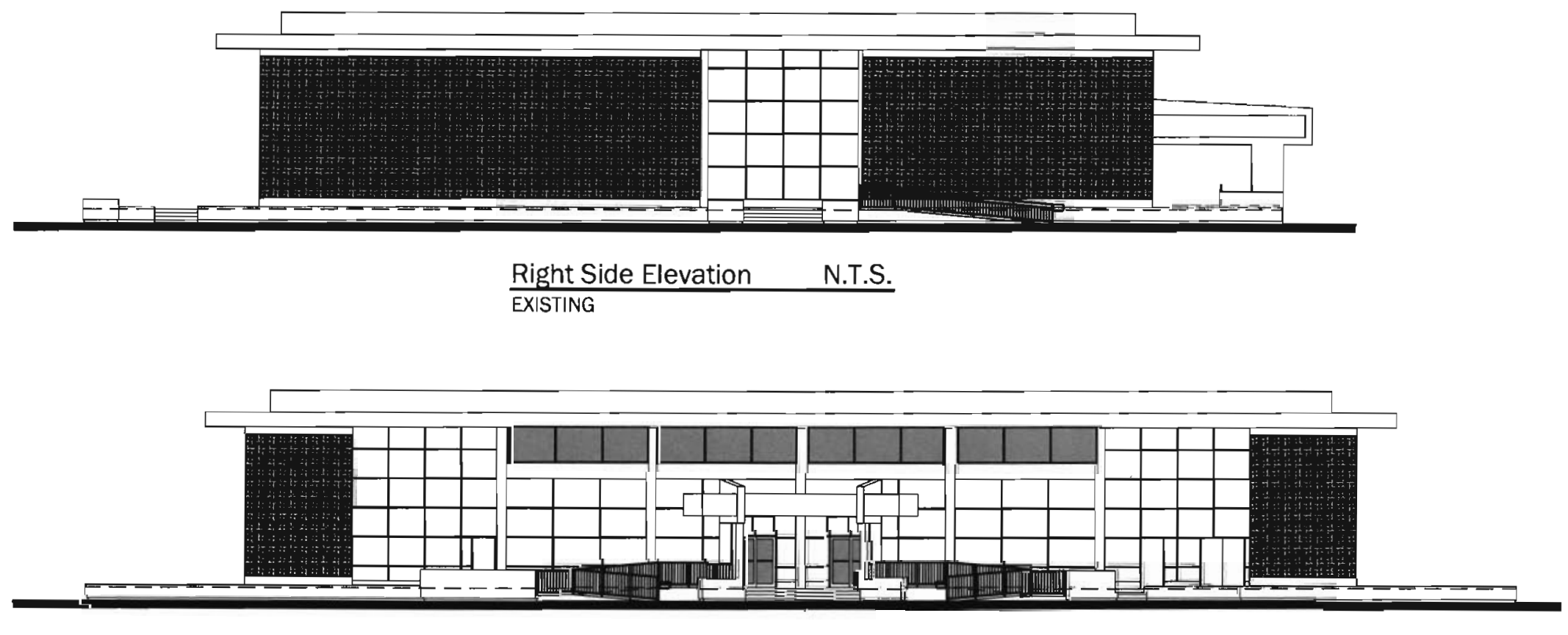

$\frac{\text { Rear Elevation N.T.S. }}{\text { EXISTING }}$ 

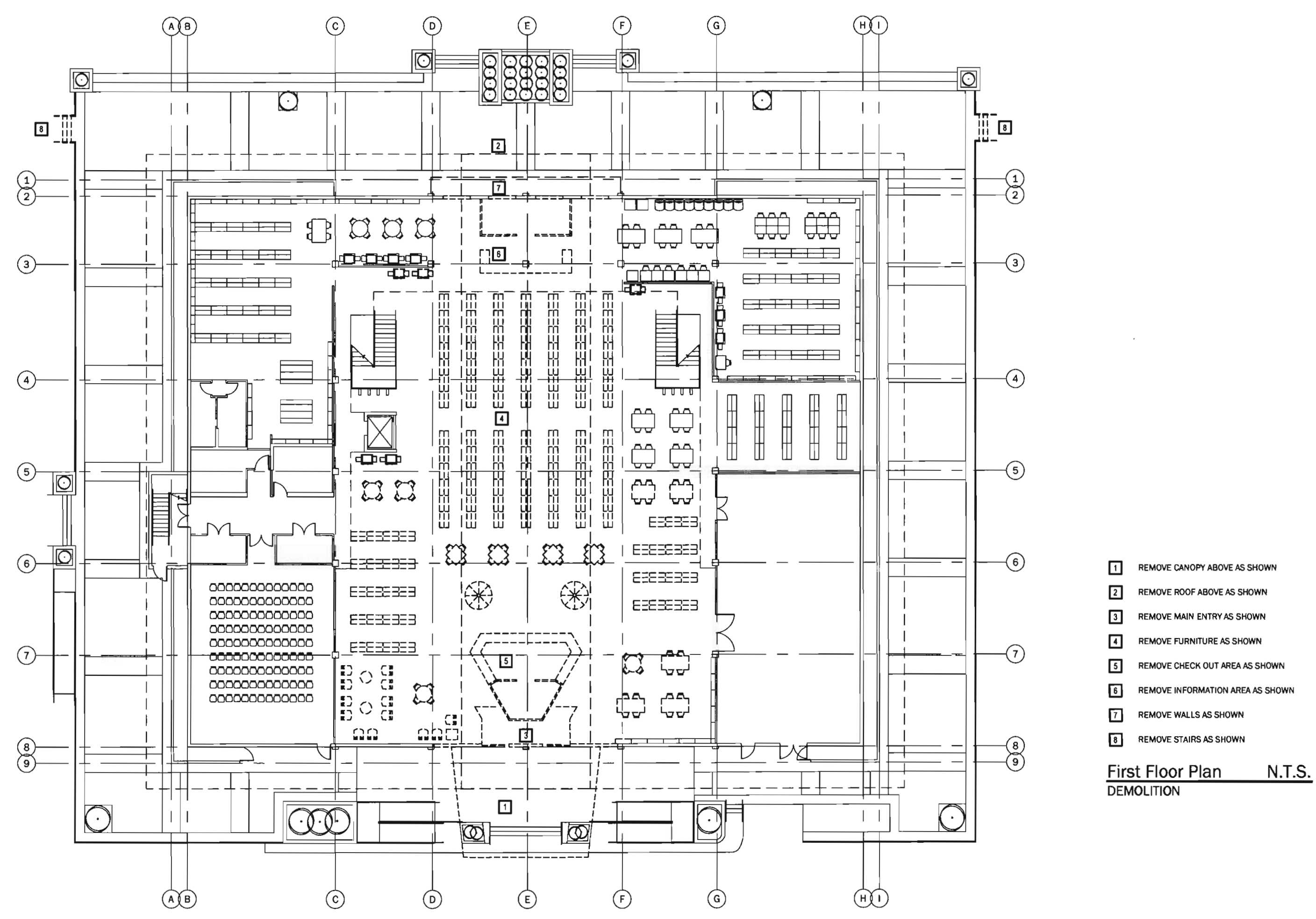


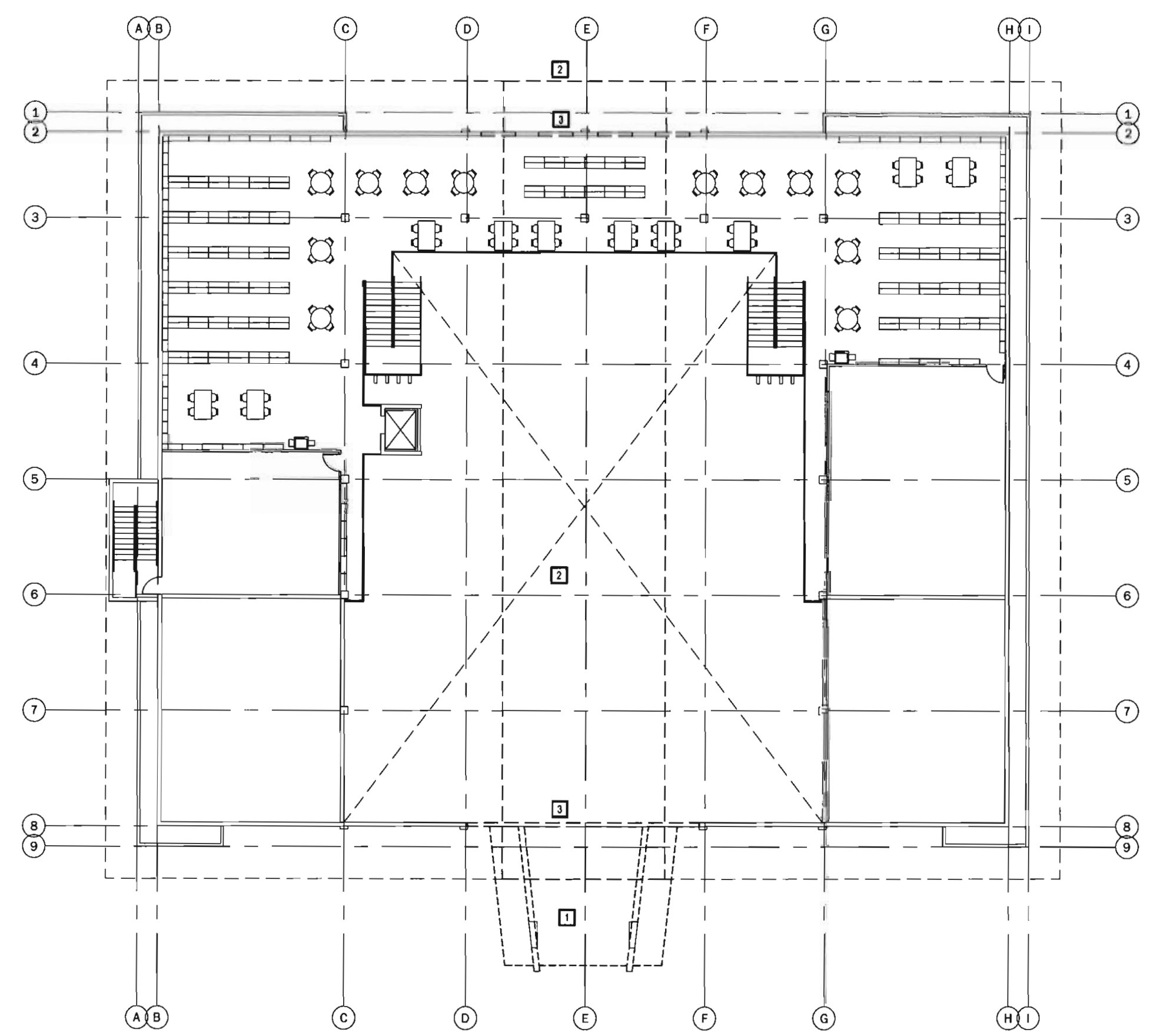
(1) REMOVE CANOPY ABOVE AS SHOWN
2] ReMOVE ROOF ABove AS SHOWN
[3 REMOVE WALLS AS SHOWN
Second Floor Plan
N.T.S.
SEMOLITION




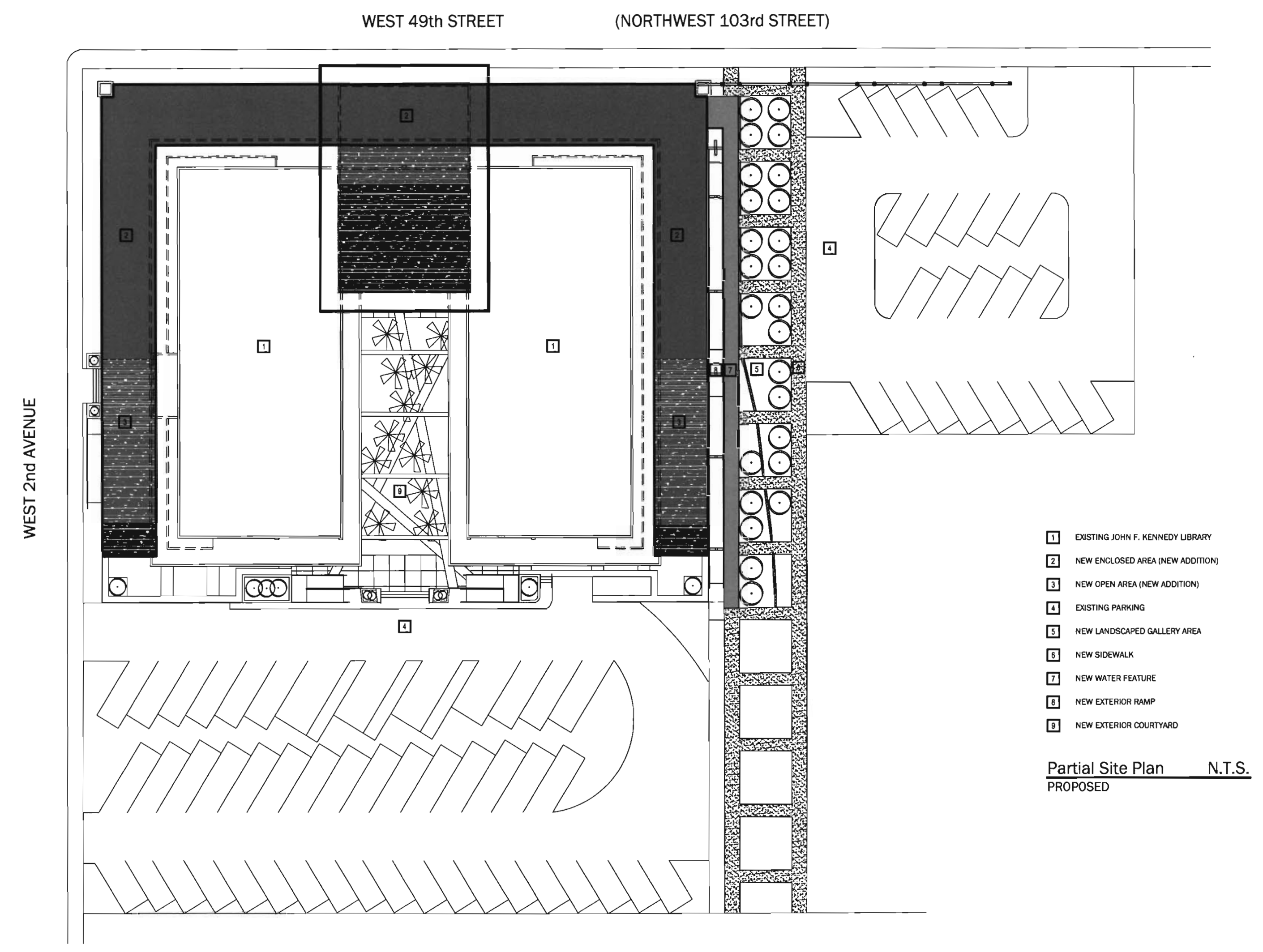




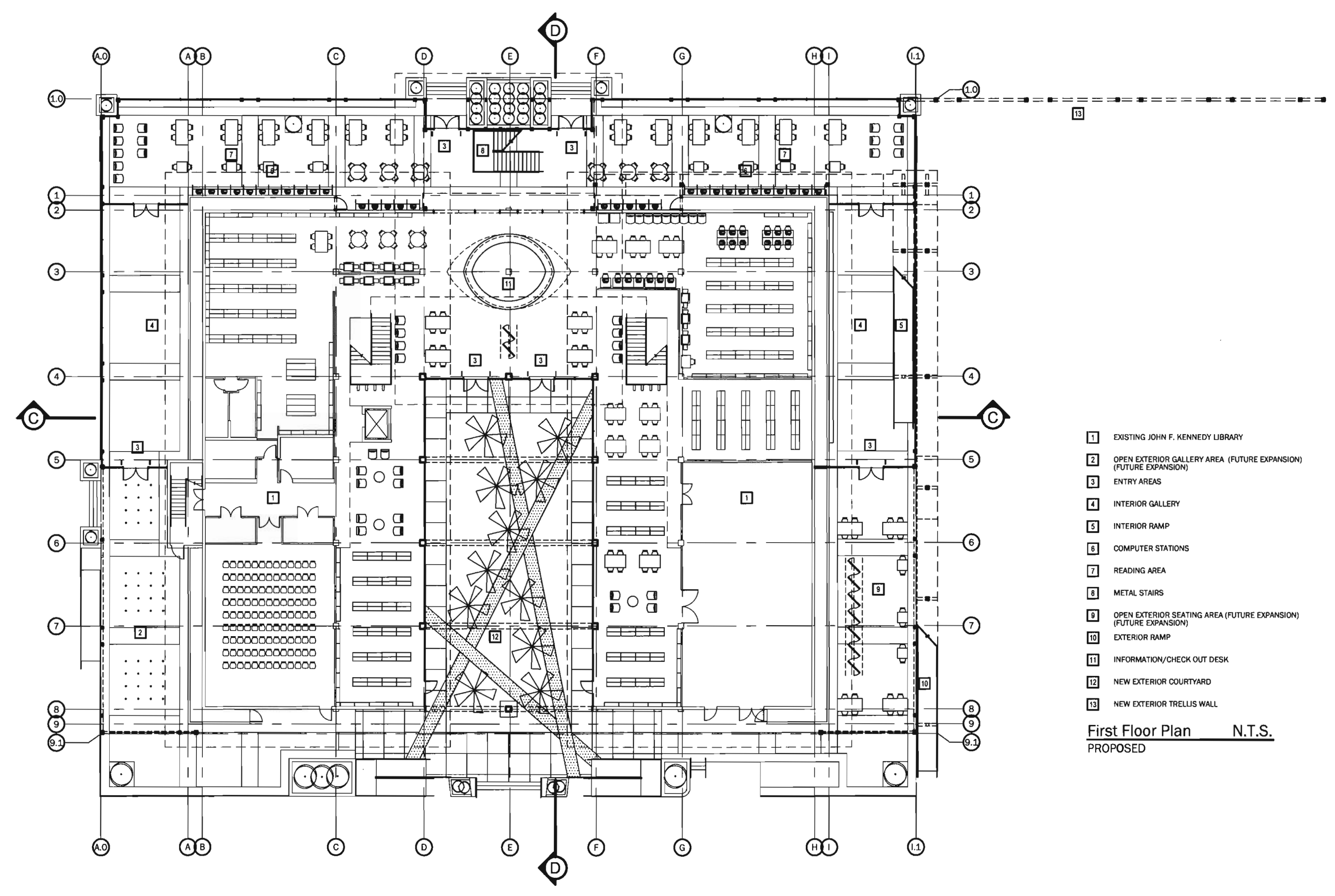




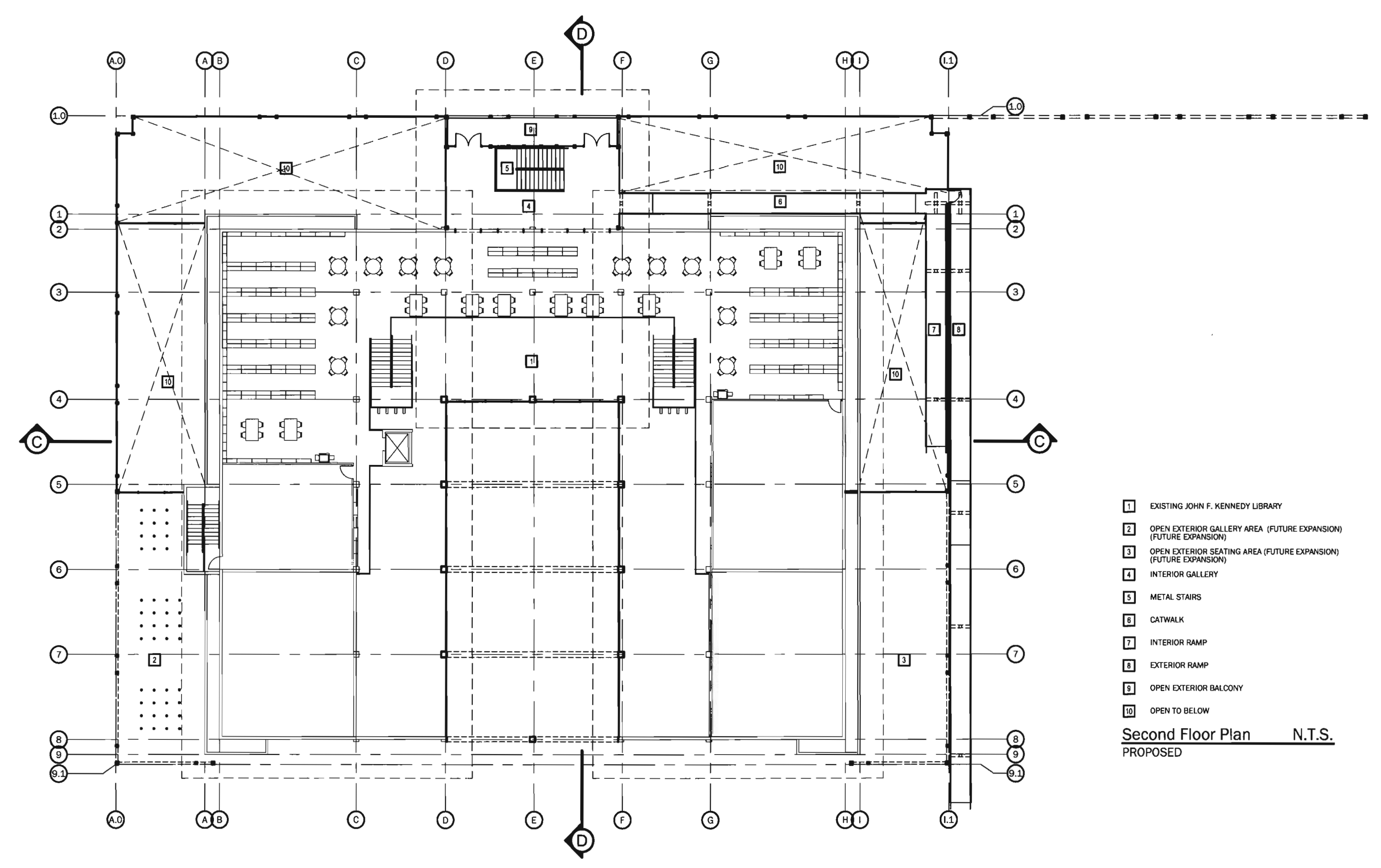




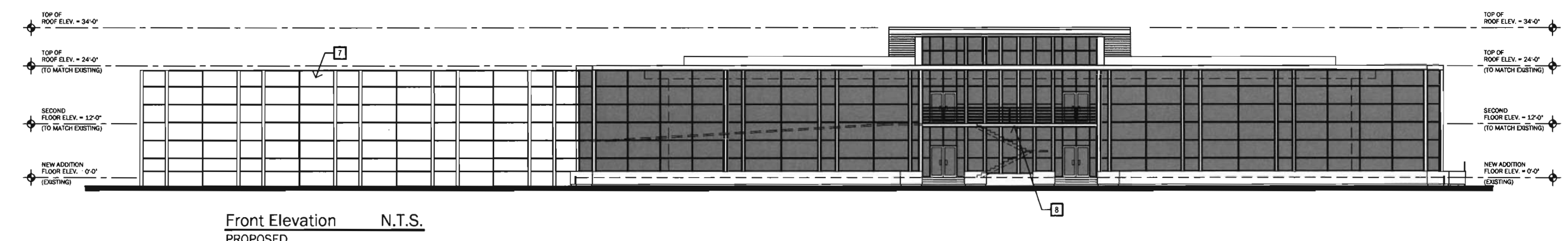
Front Elevation N.T.S.
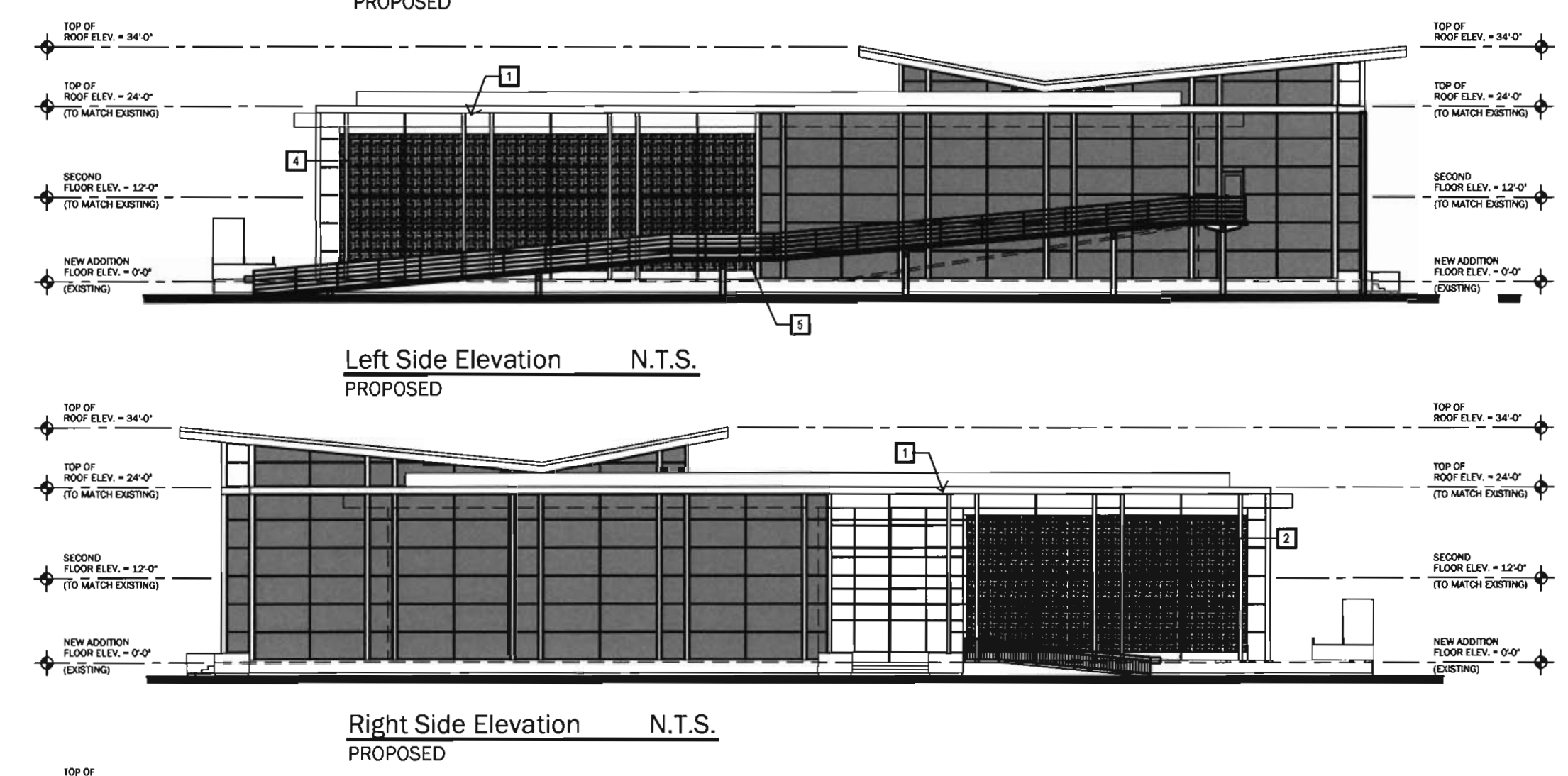

1 EXISTING J JHN F. KENNEOY LBRAPY

2. OPEN ETERROR GALERY AREA

3 ENTrY AREAS

[4 OPEN ETERROR SETING AREA

5 EXTERIOR RAMP

6 NEW EXTERIOR COURTTARO

(1) OPEN ETERIOR BALONY

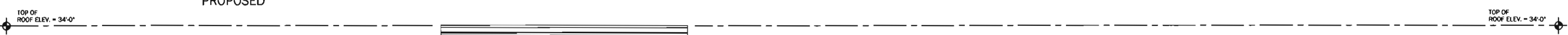

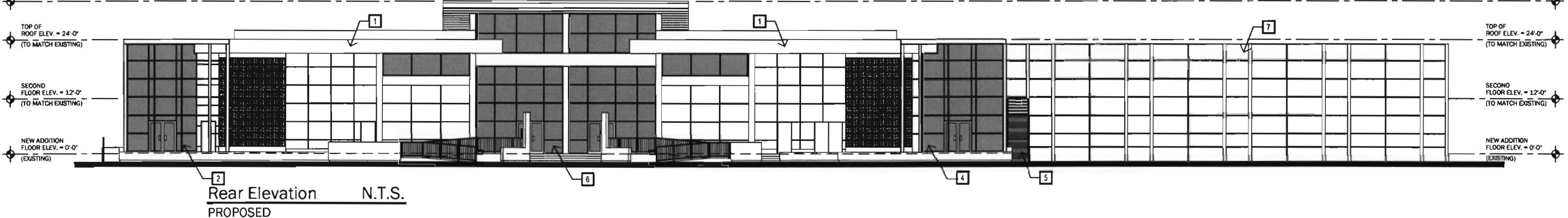




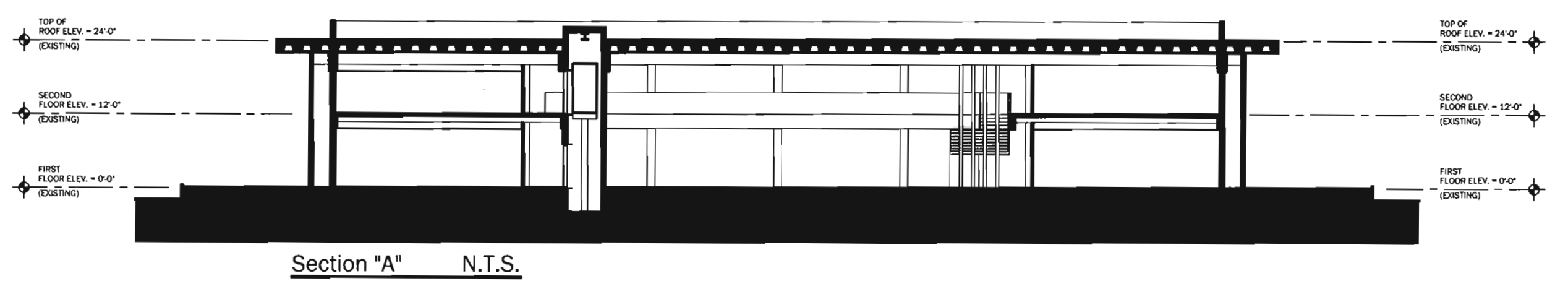

Section "A" N.T.S.

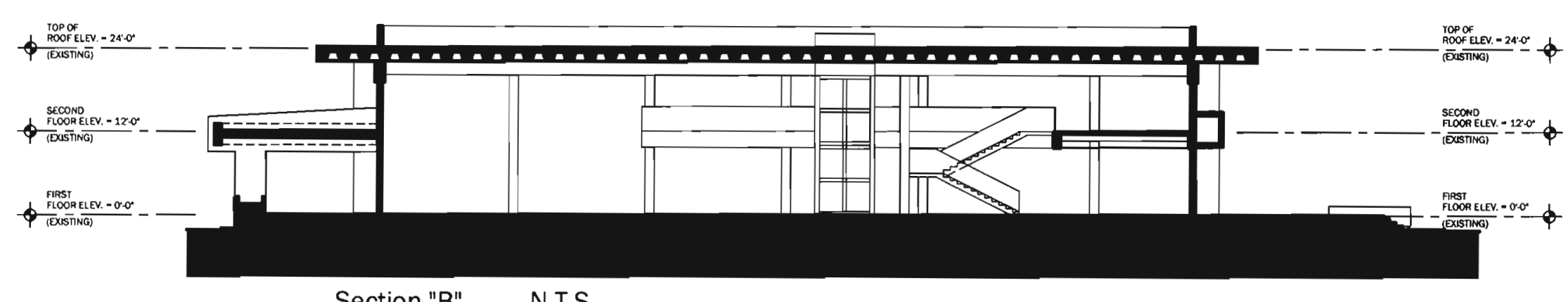

Section "B" N.T.S.
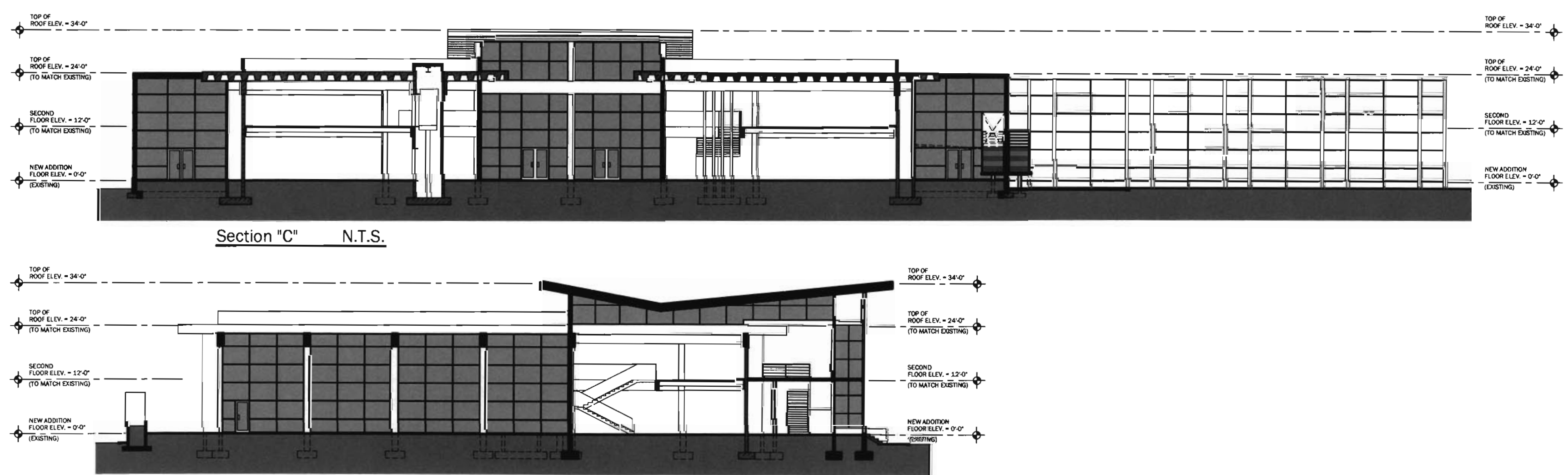

Section "D" N.T.S. 

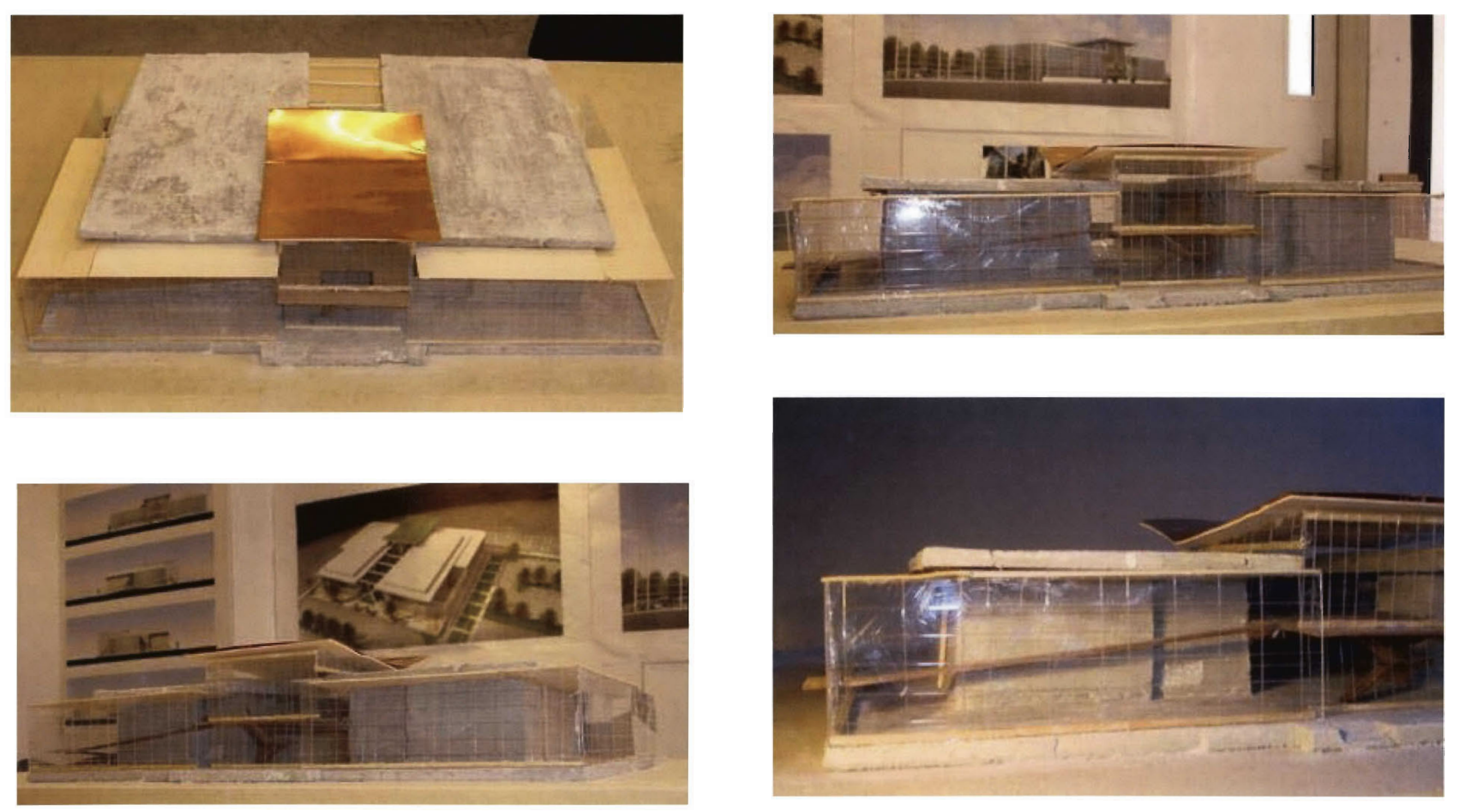

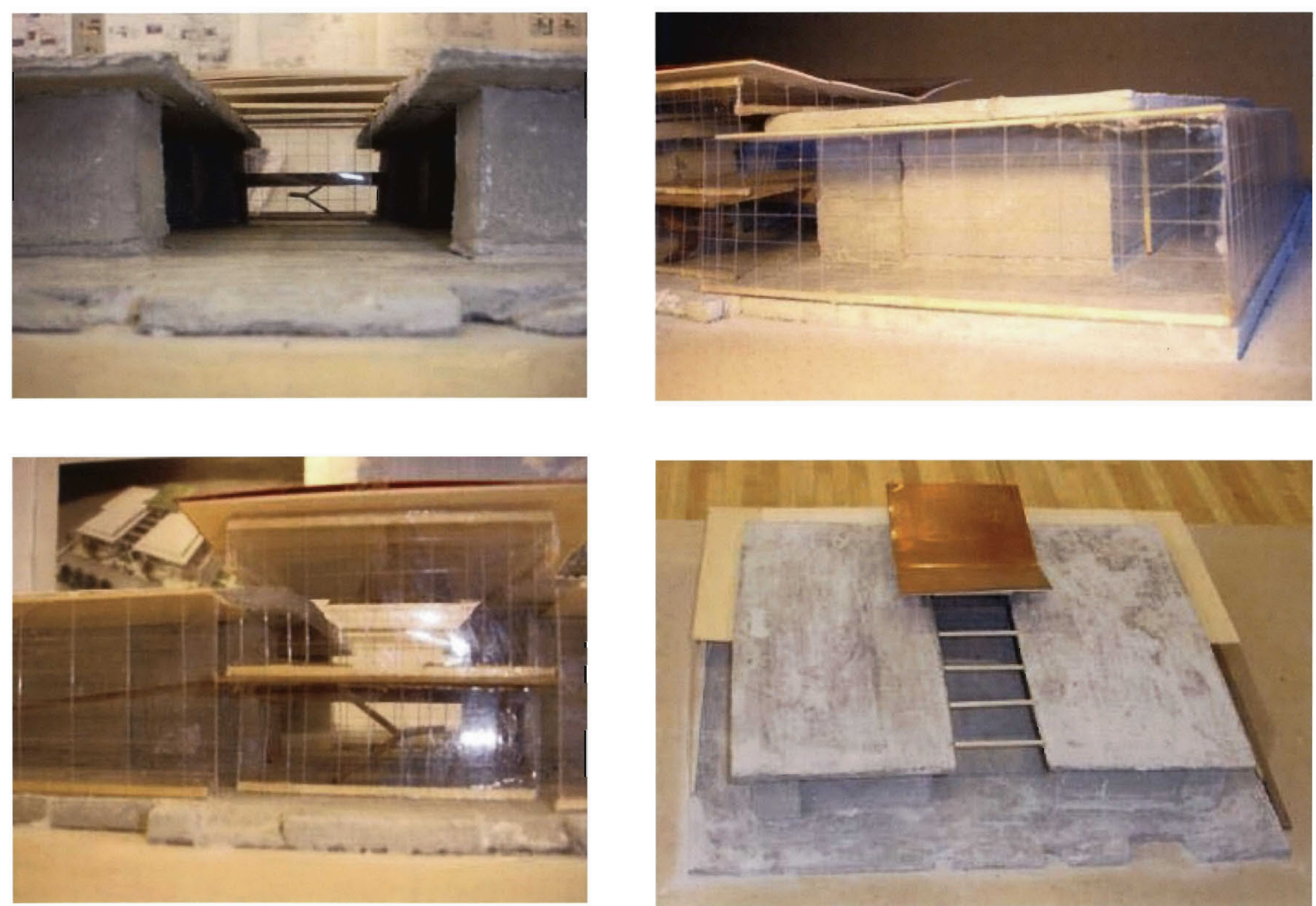

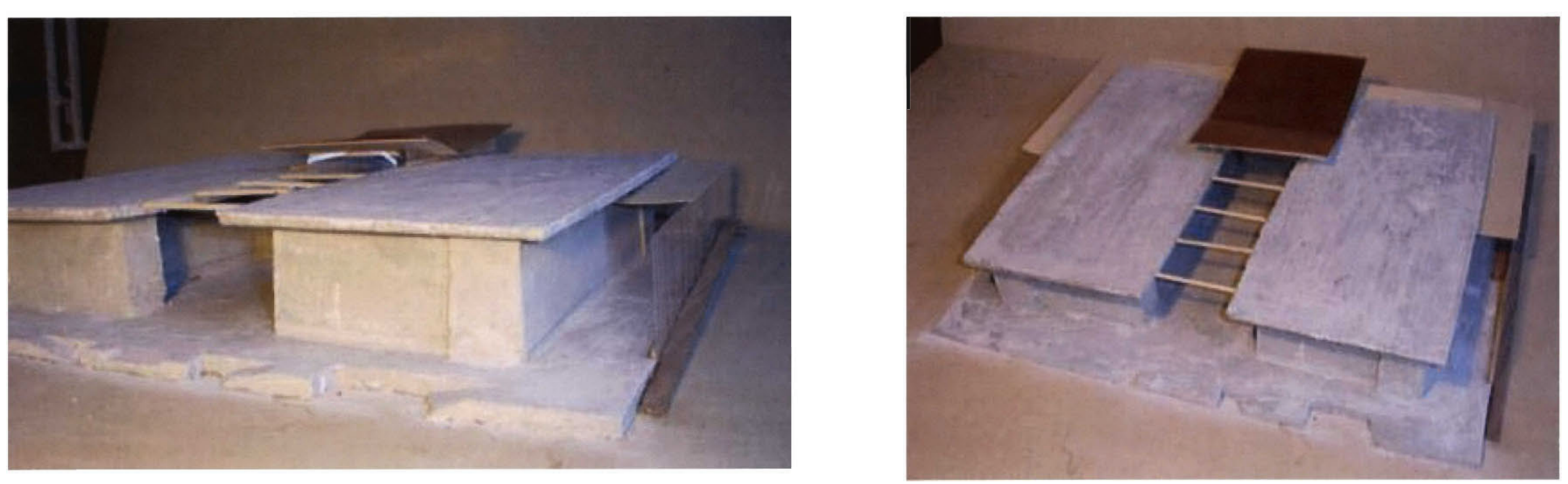


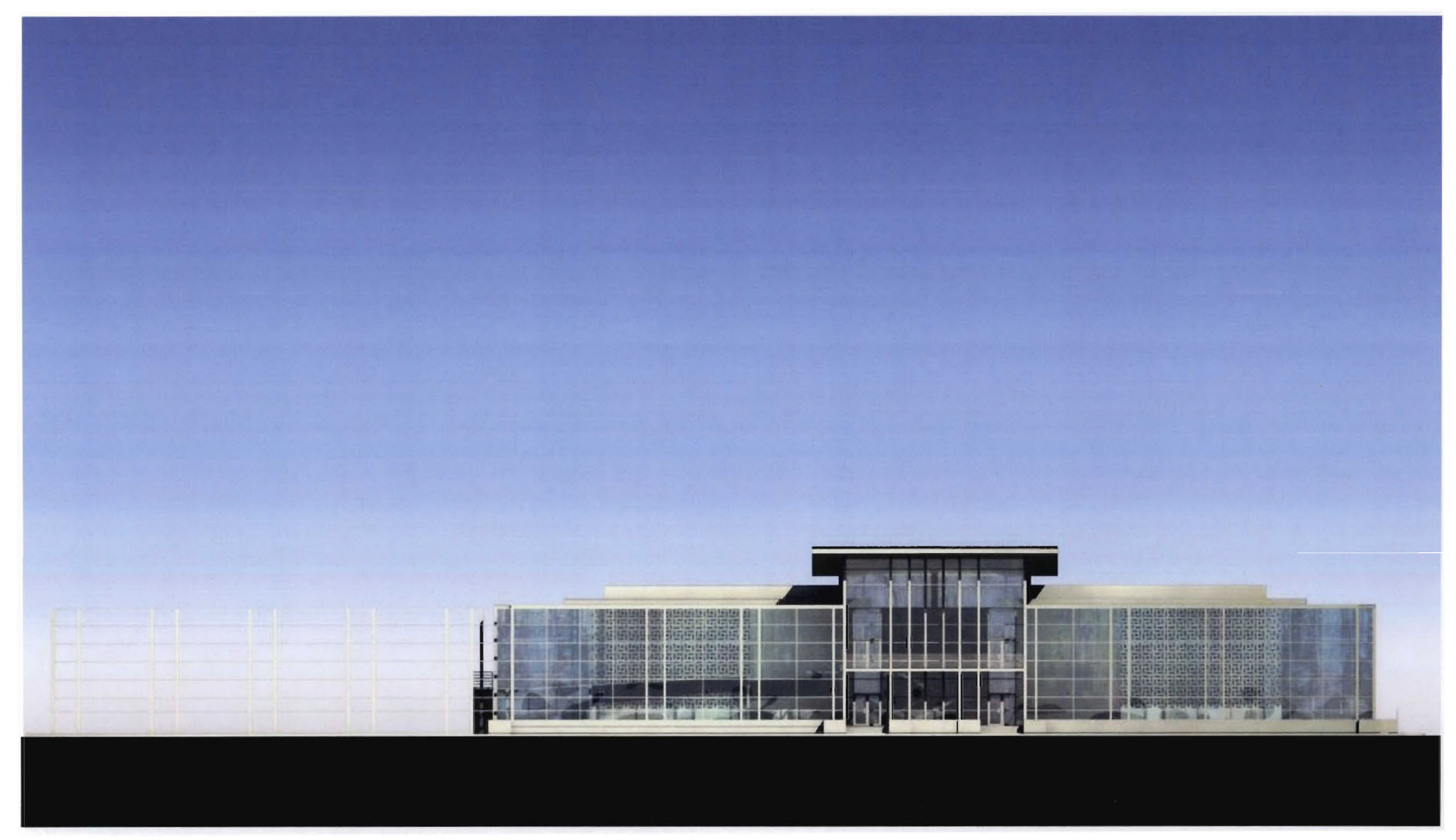

FRONT ELEVATION 


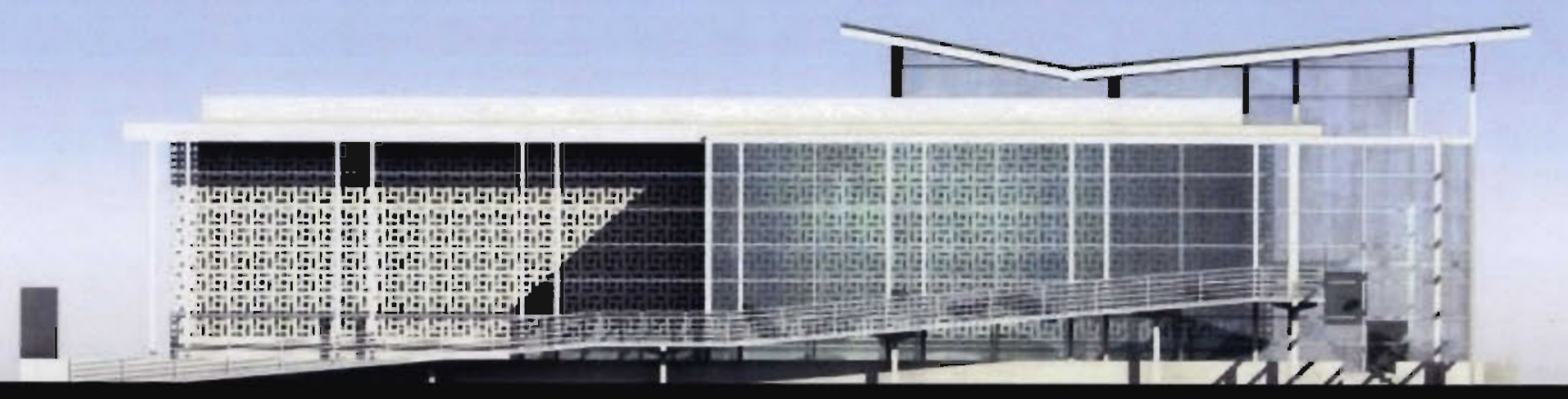

LEFT SIDE ELEVATION 


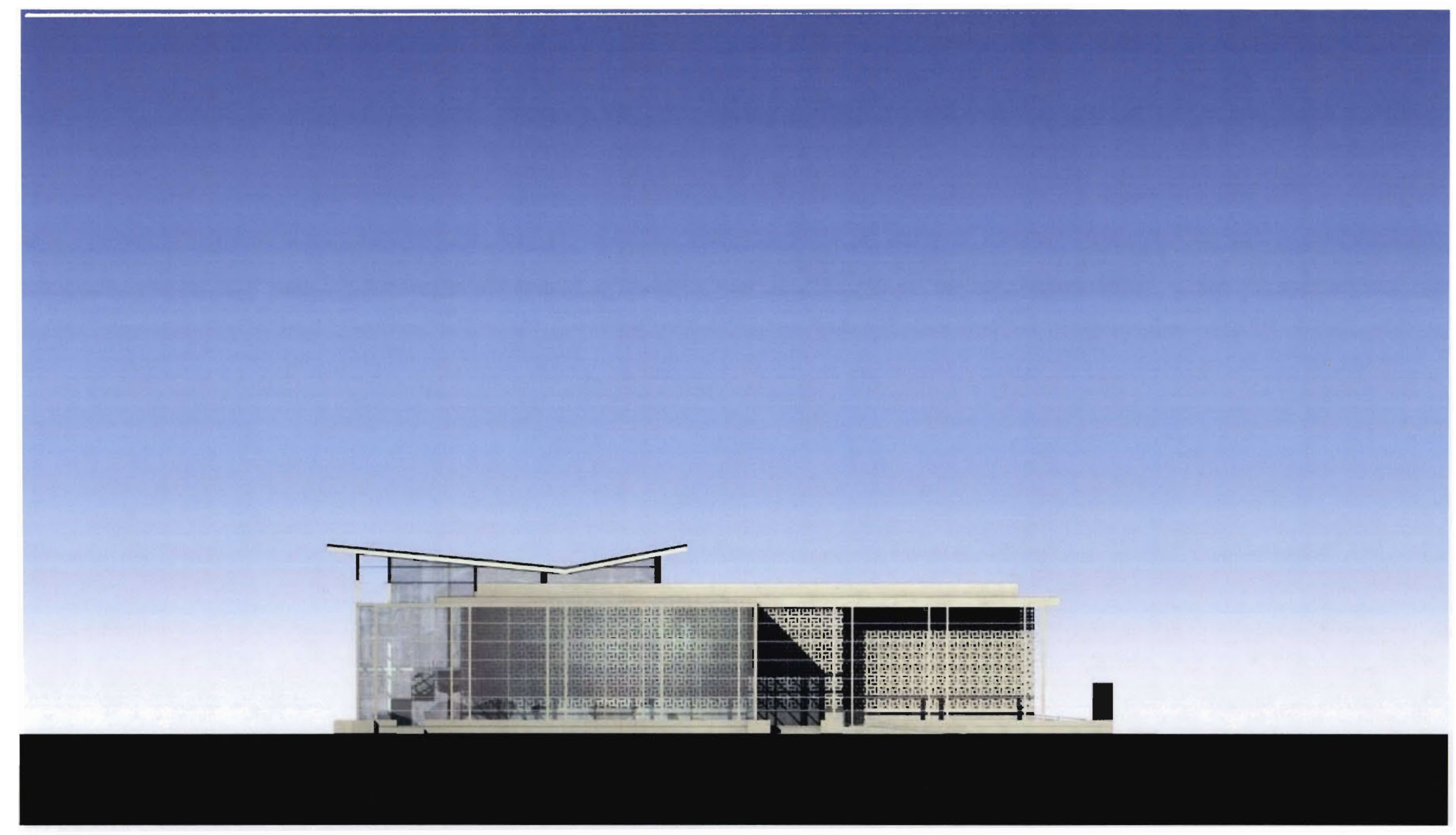

RIGHT SIDE ELEVATION 


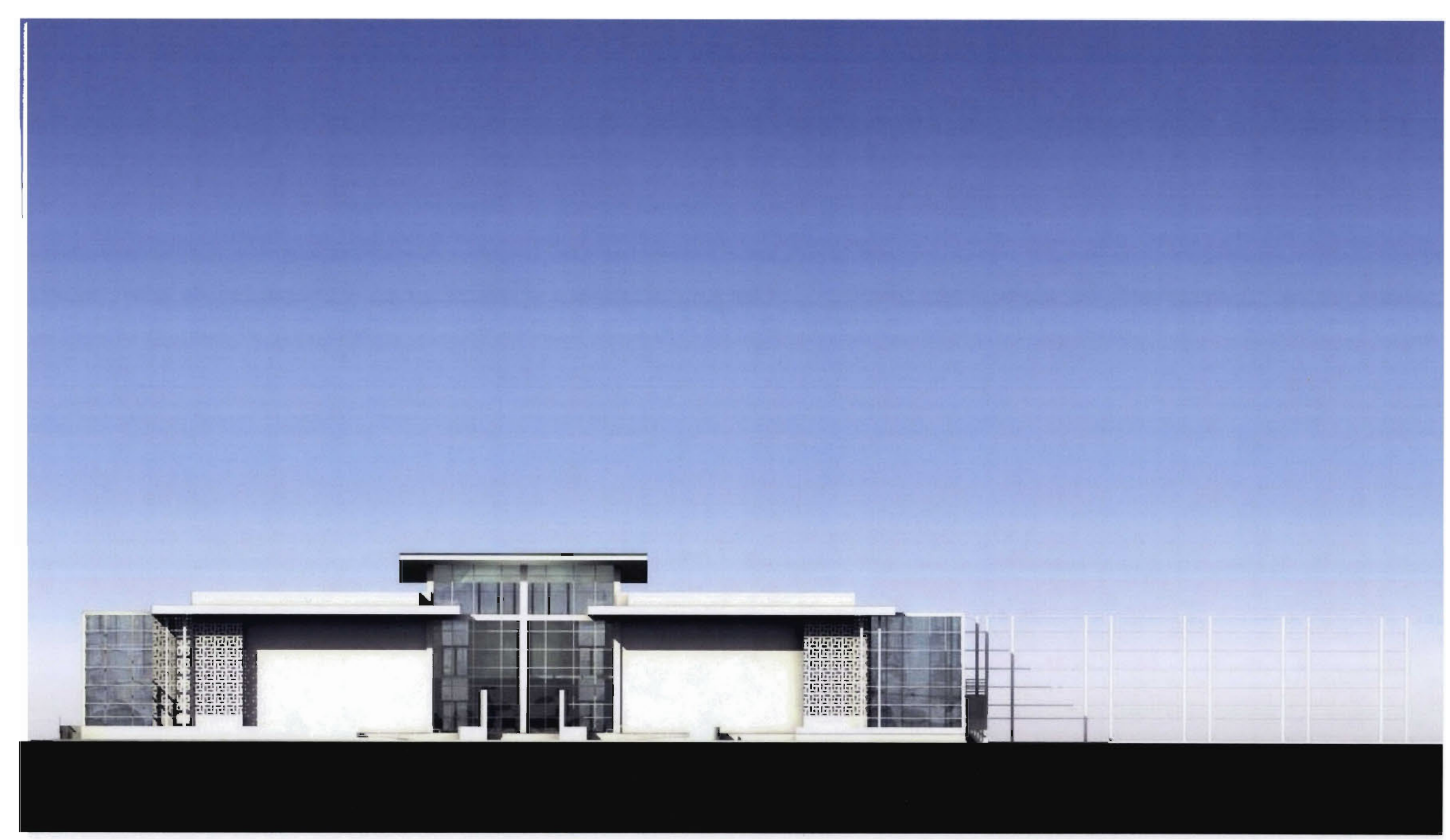

REAR ELEVATION 


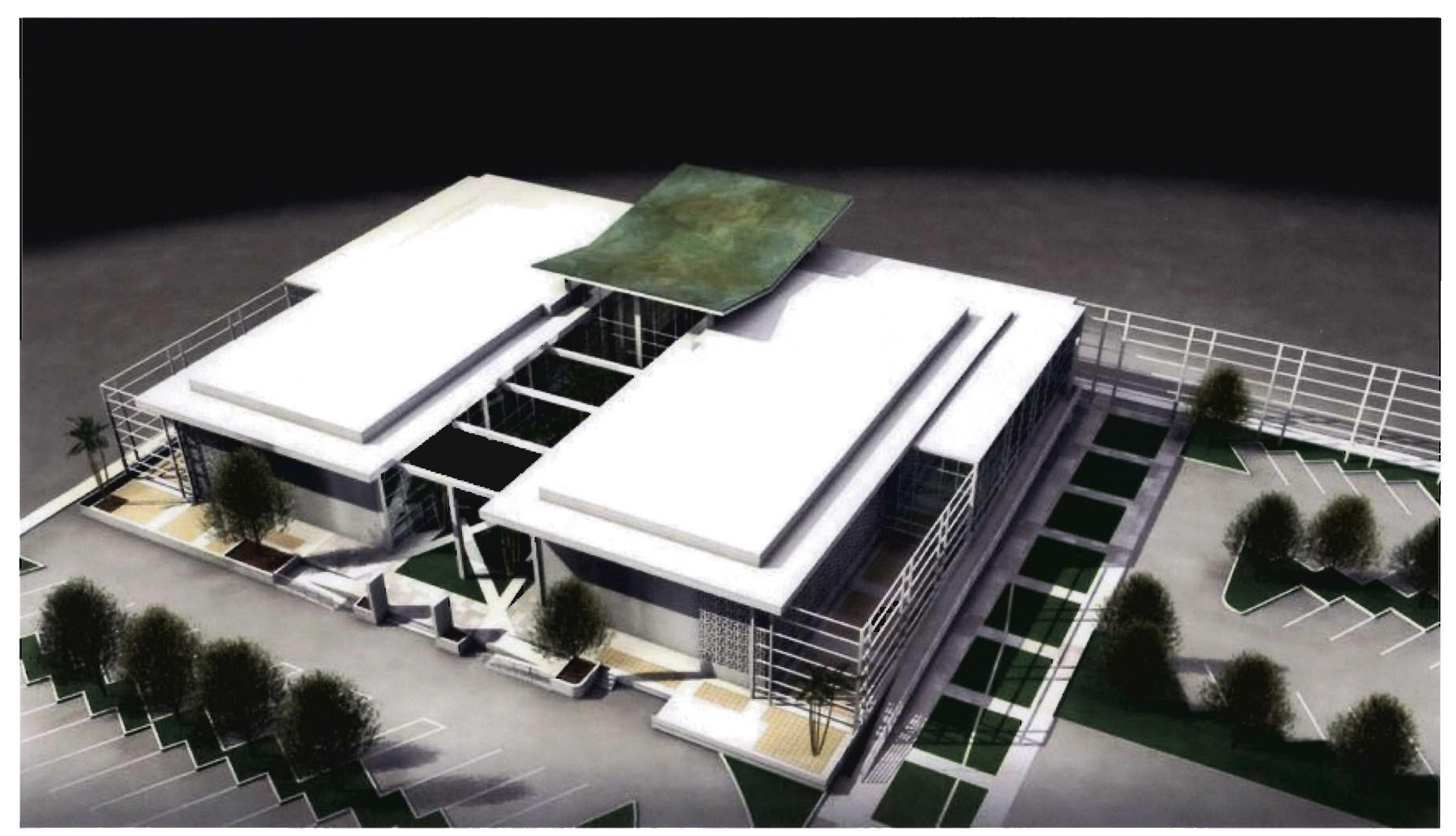




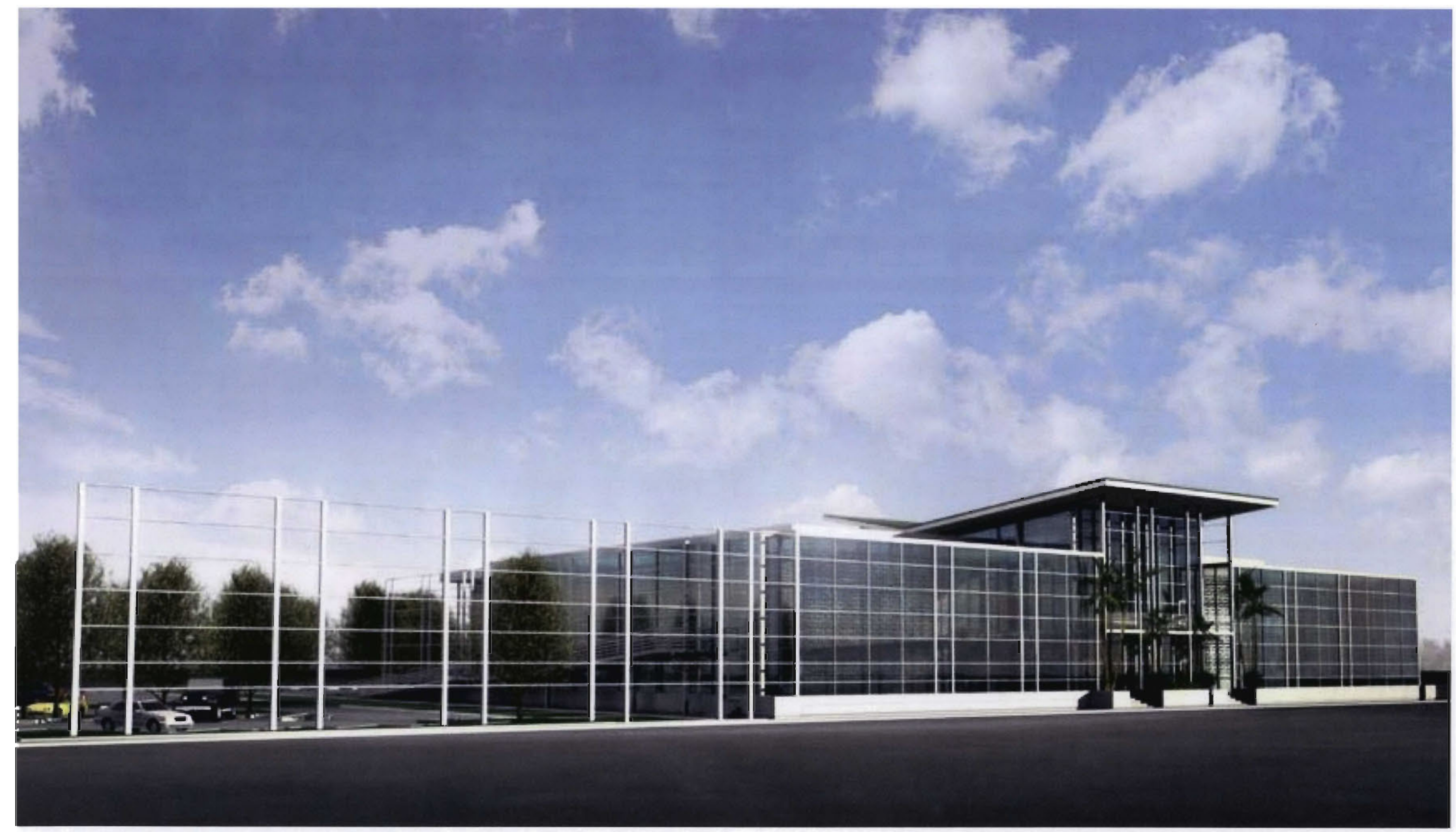




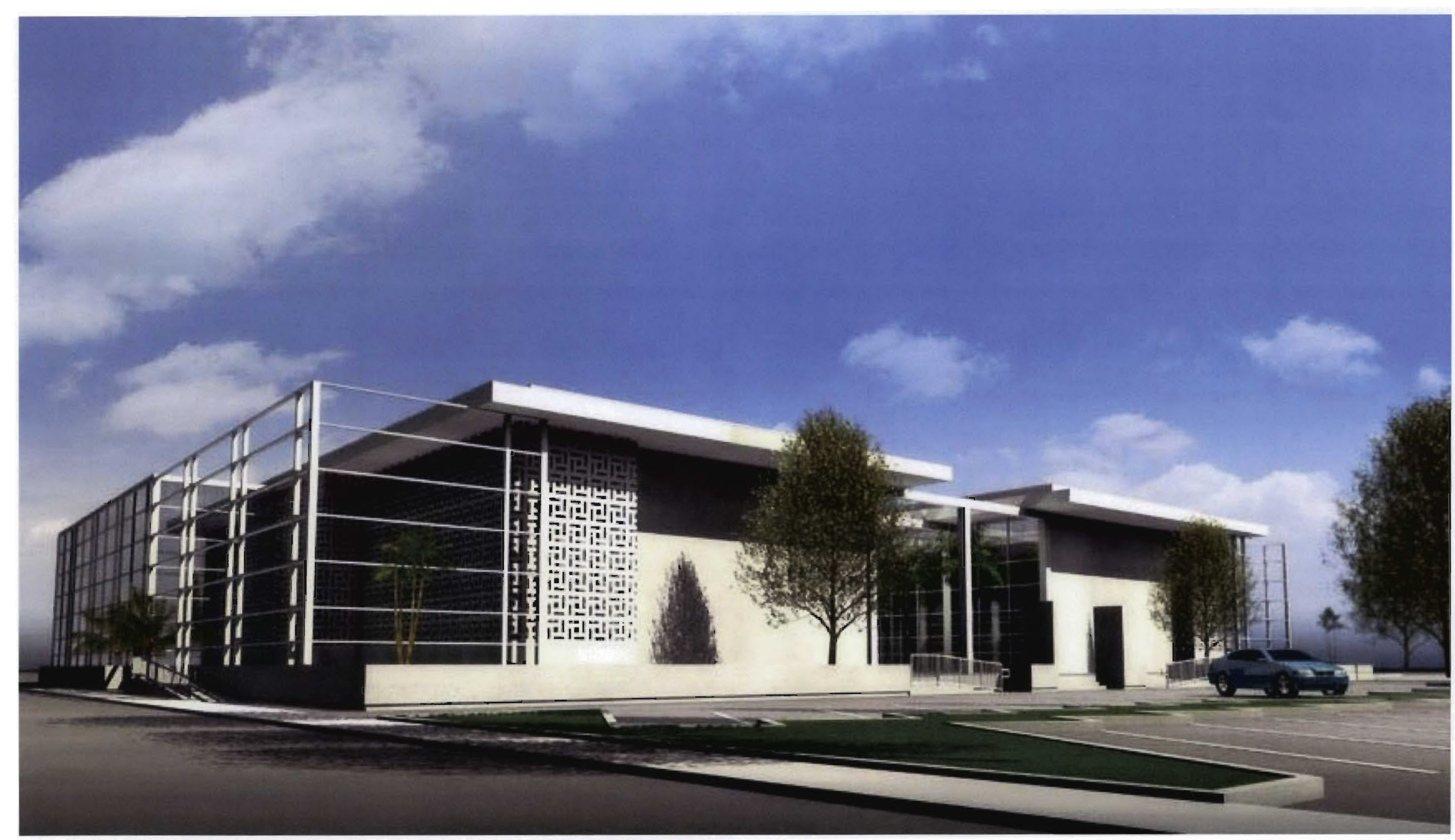




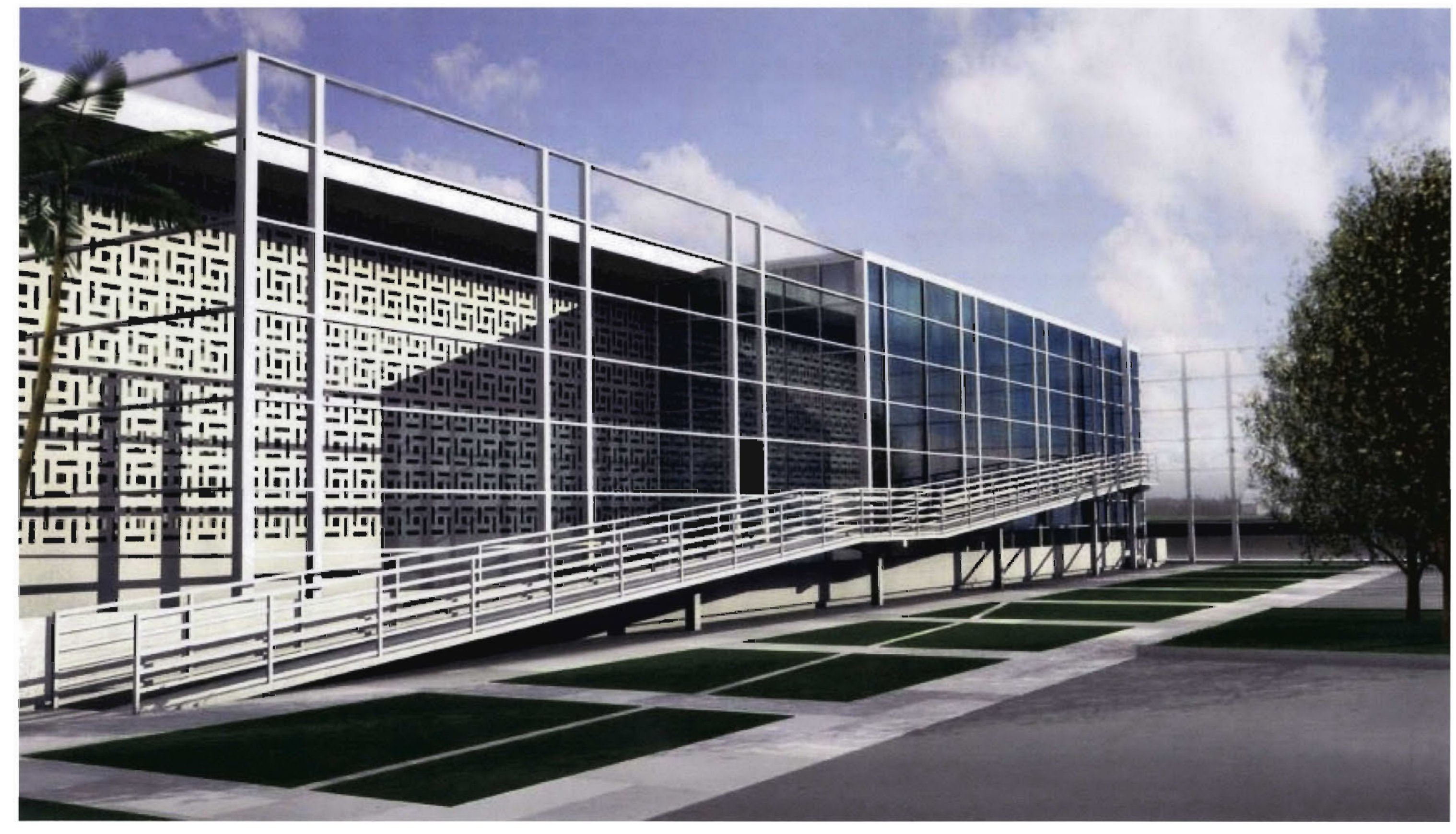




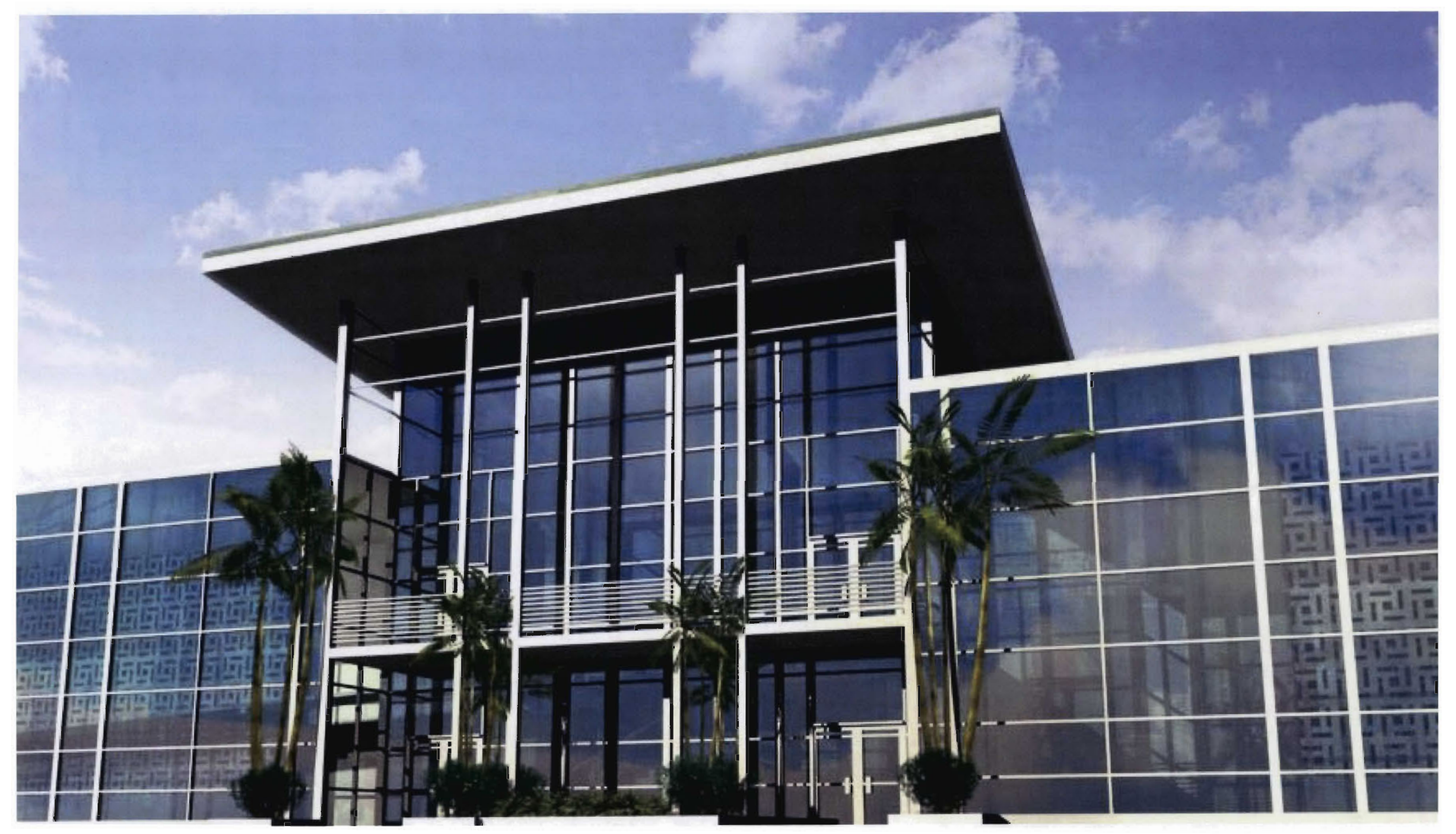




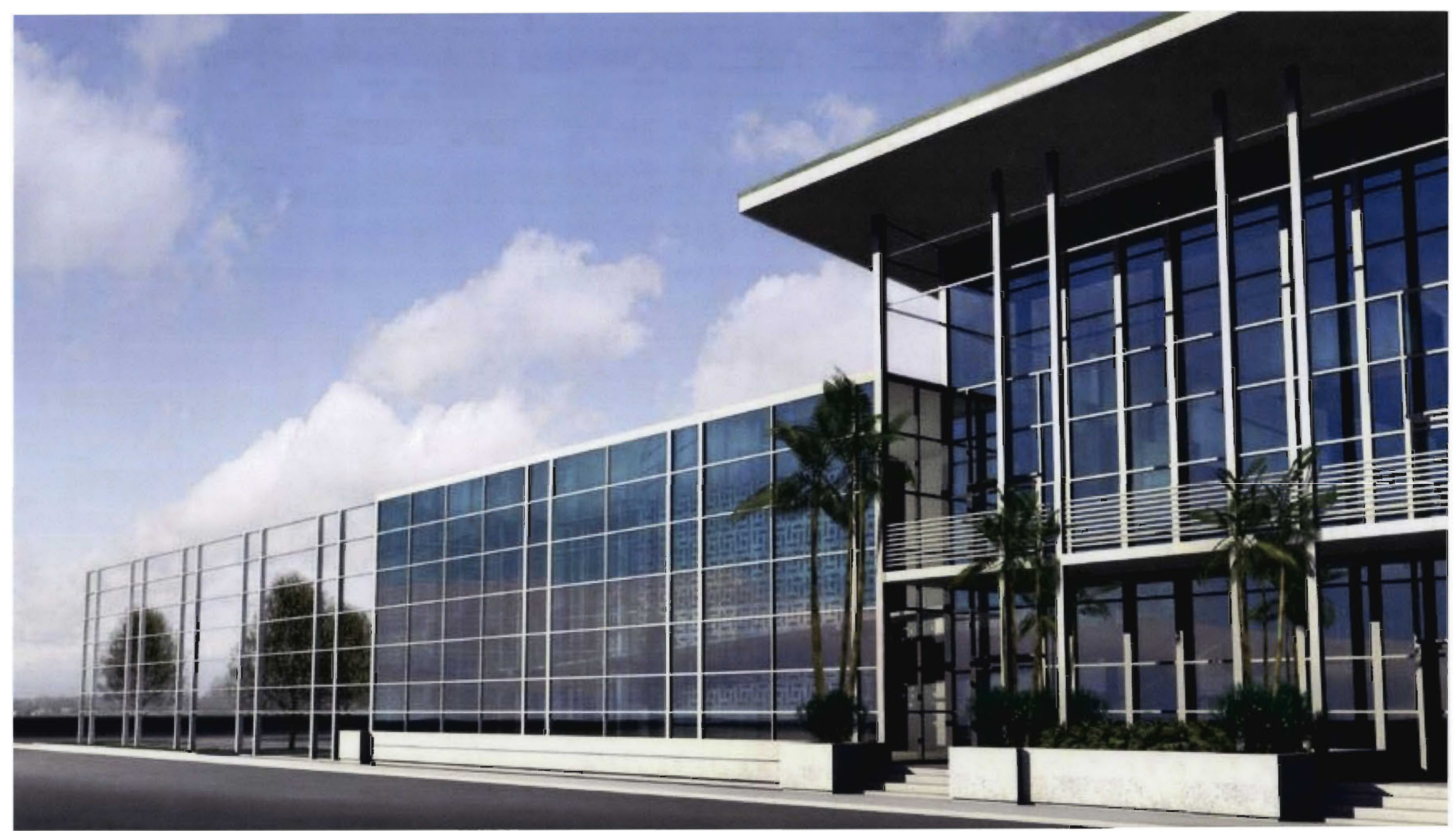




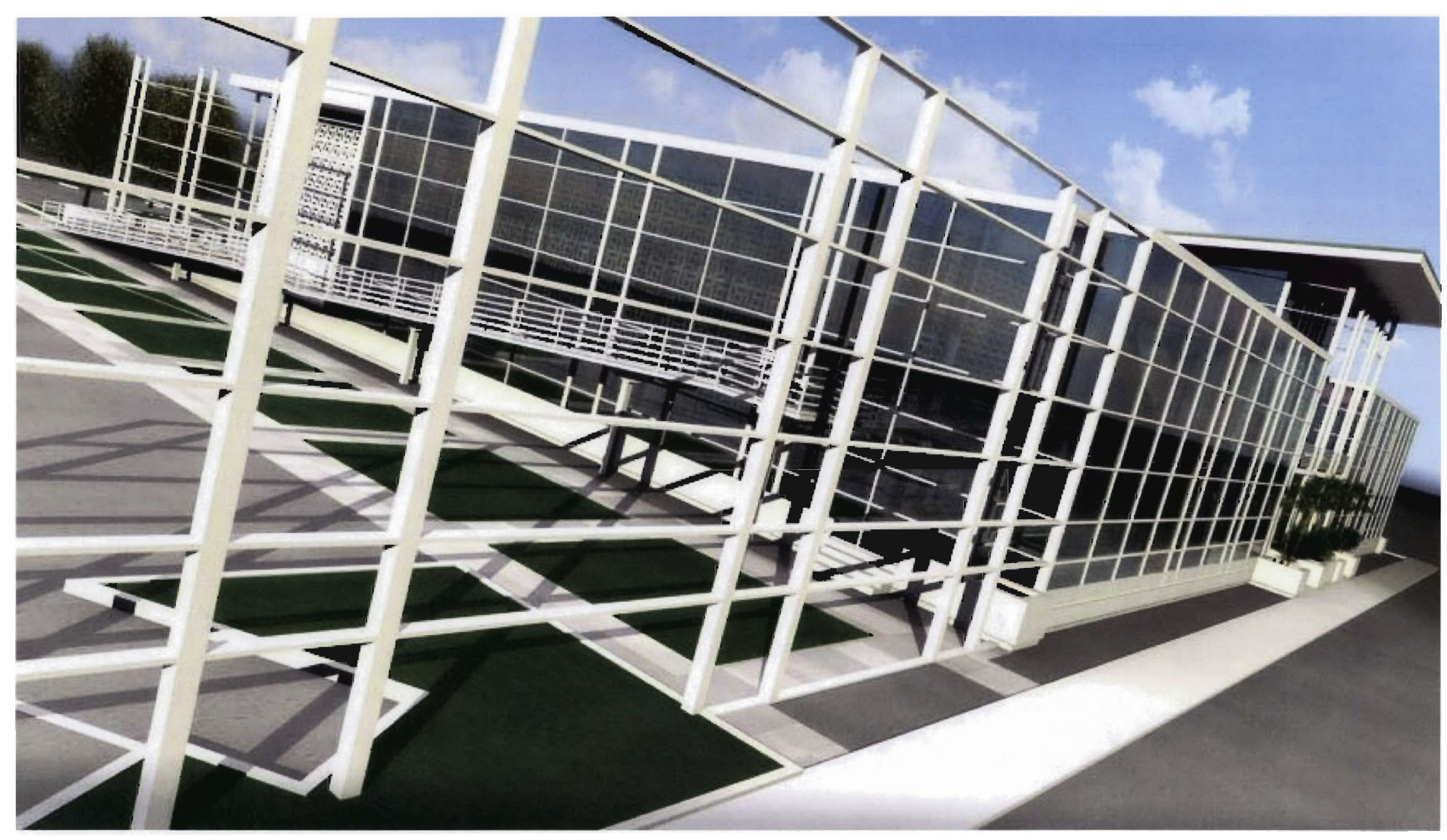




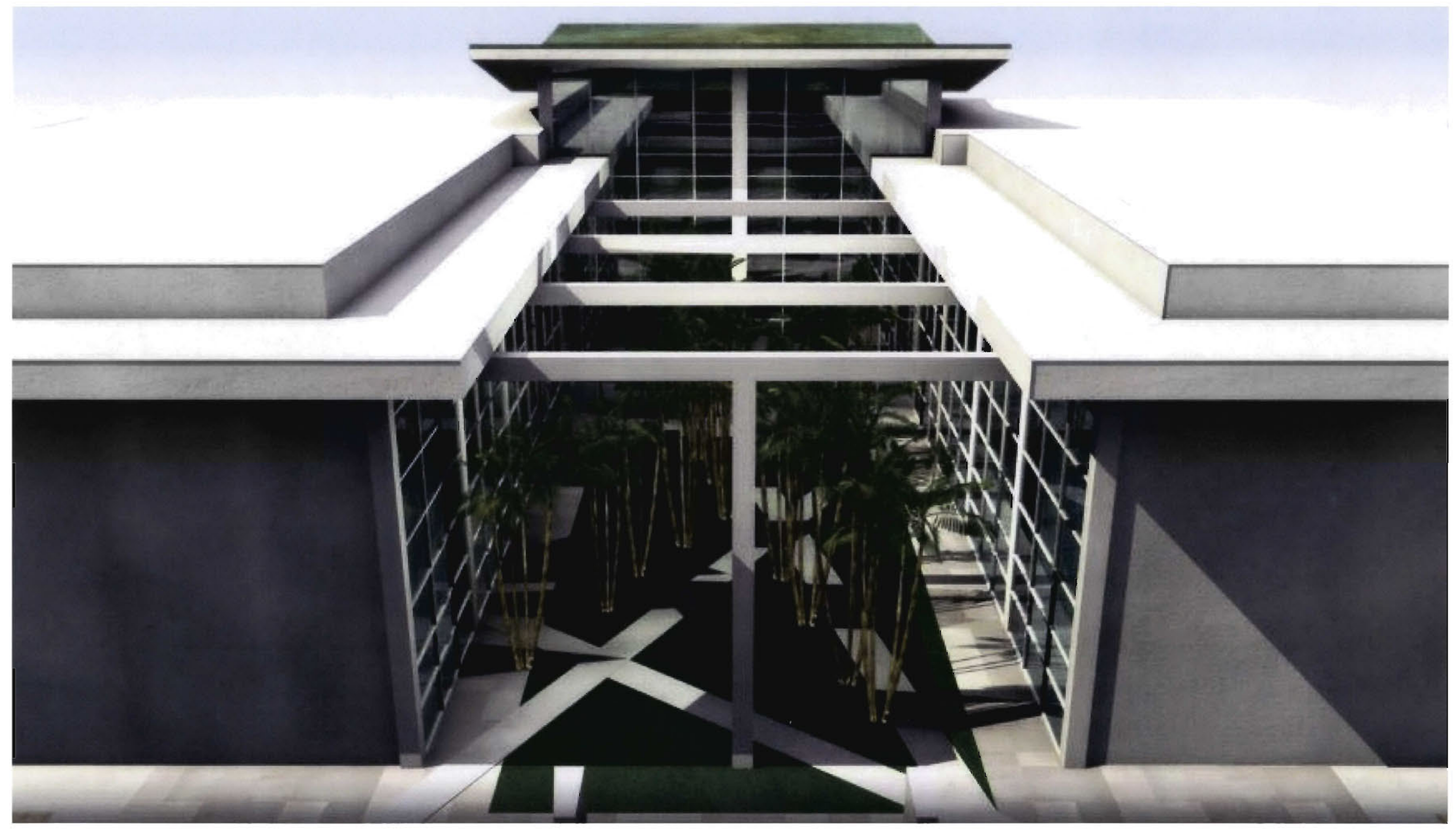



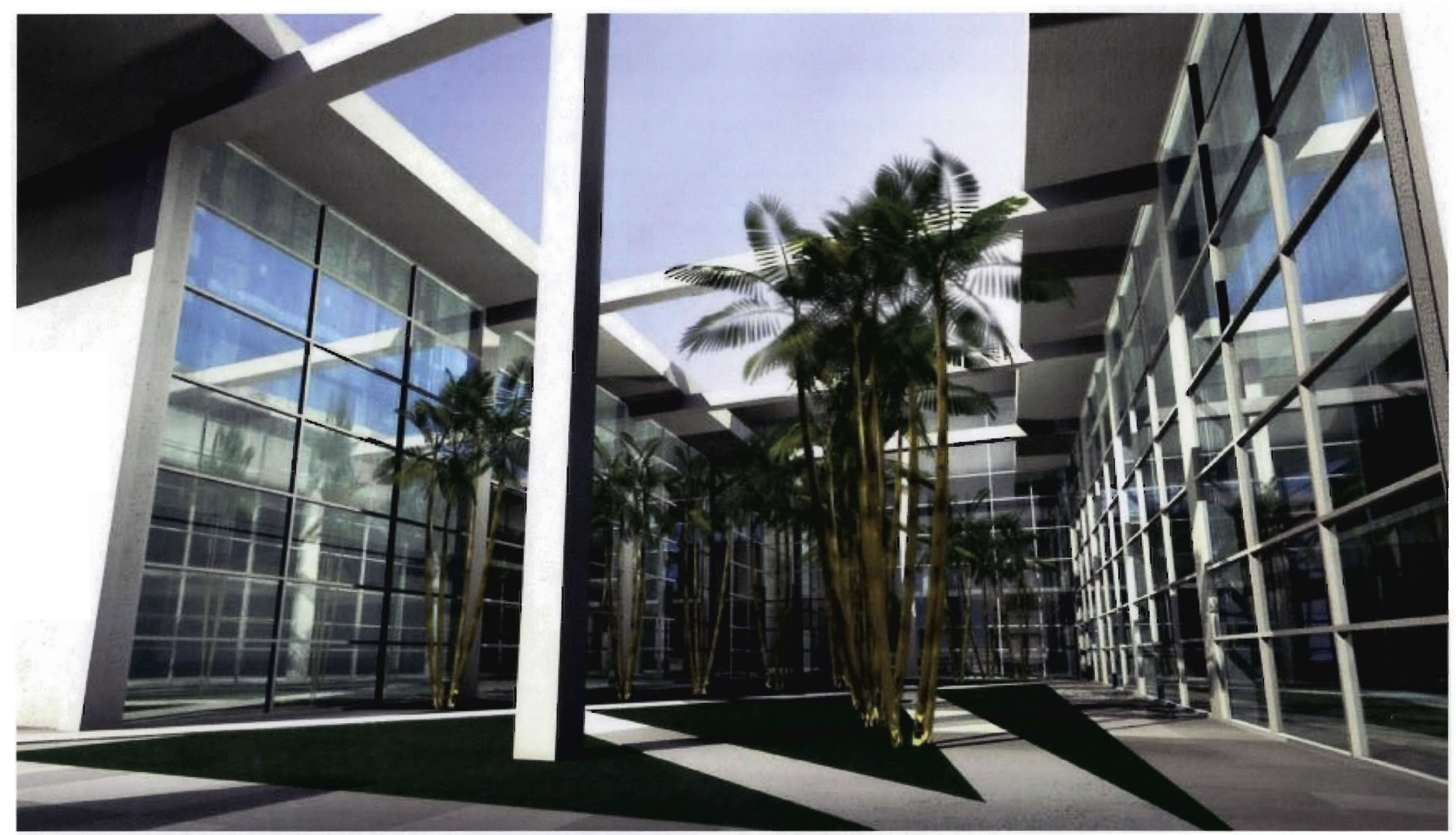


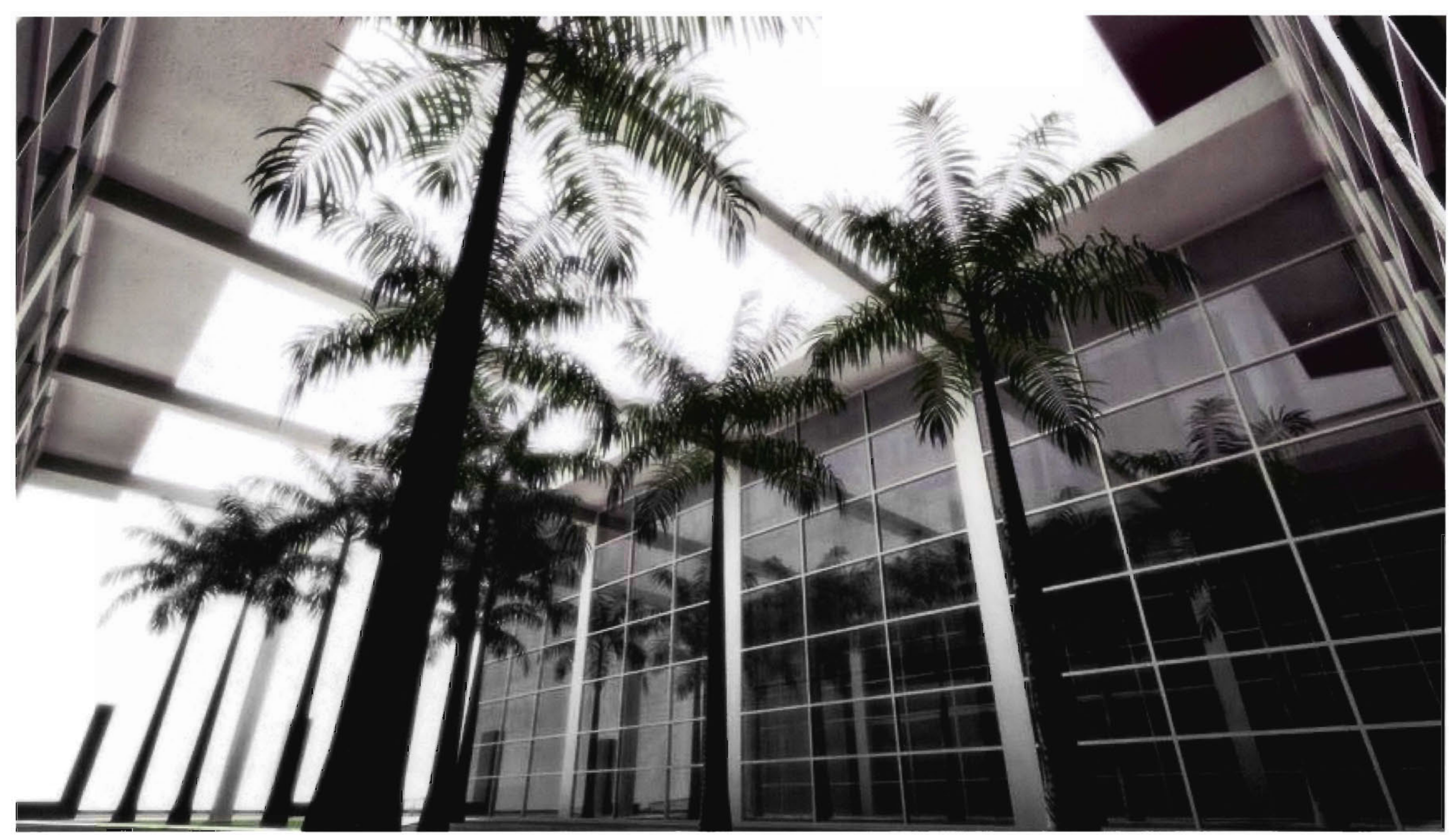

